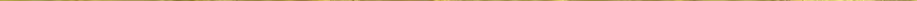




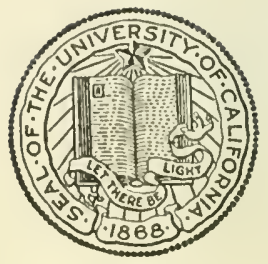

THE LIBRARY OF

THE UNIVERSITY OF CALIFORNIA LOS ANGELES 


$$
51-3 / 4 .
$$


Digitized by the Internet Archive in 2008 with funding from Microsoft Corporation 
PRAISE OF THE DOG 
UNIFORM WITH THIS VOLUME.

THE OPEN ROAD :

A Little liook for Wayfarers.

Compiled by E. V. Lucas.

Sccond Ertition.

"THIS IS MY HIRTIDDAV."

$$
\text { Cumpiled, }
$$

with apposite quotations, by Anita Barte.

With an Introduction by

ISRAEL ZANCIWLL.

London: Grant Richards. 



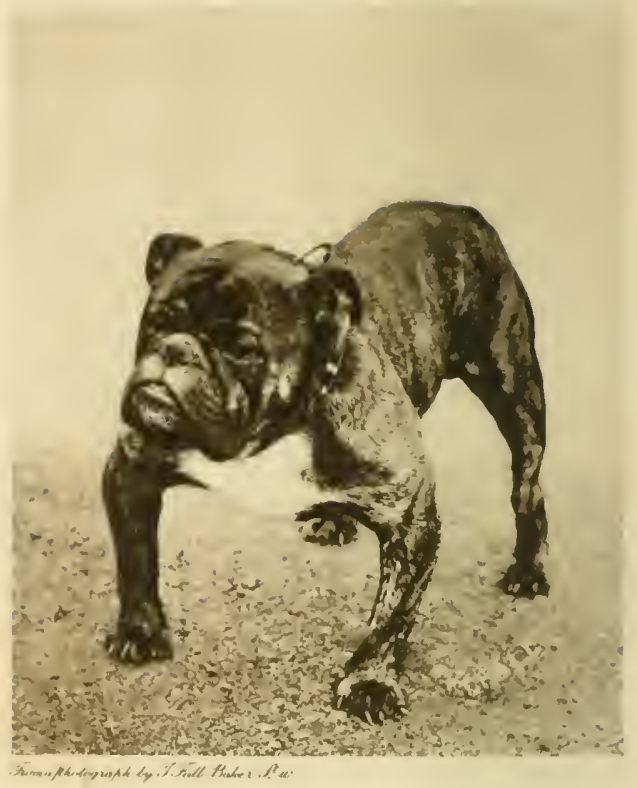

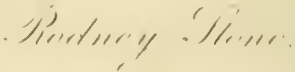

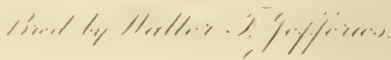




\title{
PRAISE OF THE DOG
}

\author{
An Anthology
}

COMPILED EY

ETHEL E. BICKNELL

LONDON

GRANT RICHARDS

1902 
Well, of all dogs it stands confessed, Your English Bull-dogs are the best ; I say it, and will set my hand to 't ; Cambden records it, and I'll stand to 't. 


\section{D $61=4$}

TO MY FATHER

FRANKLIN T. RICHARDS

852312 



\section{NOTE}

FOR leave to print the following poems and prose I have to thank Mliss Armstrong for her Carrier Dog of Berlin; Professor Butcher and Mr. Andrew Lang for the lines on Argos from their translation of the Odyssey; the Rev. Alfred J. Church for his translation of an Epitaph on a Dog; Professor J. Courthope for his A Blenheim's I'alentine; Mr. Thomas Hardy for an extract from Far from the Madding Crowd; the Rev. Frederick Langbridge for Mike Hourigan's Pup; Mr. Robert C. Lehmann for A Retriever's Epituph, and Rufus; Mr. Alfred Olivant for two extracts from Oud Bob; Mr. Louis Robinson for an extract from his Wild Traits in Tame Animals; Sir George Trevelyan for two quotations taken from his life of Lord Macaulay; Mr. Willian Watson for leave to print $A n$ Epilaph, and the first half of a cat and $\operatorname{dog}$ poem entitled $A$ Contrast; and Mr. vii 
Henry Willett for a hitherto unpublished poem, In Mimoriam.

I wish also to thank the following Editors and I'ublishers for their courtesy in letting me print matter which is their copyright:-Messrs. Adam and Charles Black for extracts from Dr. John Brown's Horce Subsciva; Messrs. Bradbury and Agnew, Proprictors of Punch, for liufus (Punch, Jan. I, 1902); Mr. John Lane for A Retriever's Epitaph (Anni Fugaces); Messrs. Macmillan for A Dog of the Fusiliers (Macmillan's Magazine, May I 860), and also for their leave to use a quotation from the translation of the Odyssey by Messrs. Butcher and Lang; Messrs. Smith Elder and Co. for Tray; Mr. John Murray for his leave, and also for obtaining leave of Mr. Darwin's family, to print extracts from two of Mr. Darwin's books; the Editor of the Spcctator for leave to print Mike Hourigan's I'up (Spectator, Mar. 28, I 901 ), the Carrier Dog of Berlin (April 20, I901), and $A n$ Epitaph on a Dog (Feb. I, 1902).

I must also thank Mr. Neville E. Cobbold for his kind help; and above all 1 must thank my father for certain quotations from the Latin, and his help and advice.

To the Reader let me apologise for the many omissions he will, 1 fear, find; if he will give me the reference for anything of interest which I have overlooked, I shall be most grateful. 
Nothing has been inserted of which the English appears so old as to be a difficulty to the modern brain and ear; and for this reason a considerable body of poetry from Chaucer onwards has been discarded.

I am unfortunate in having failed to get leave to print Lord Tennyson's Owd Roü, Miss Christina Rossetti's A Poor Old Dog, and Mr. Matthew Arnold's Geist's Grave, Kaiser Dead, and that part of Poor Matthias which tells of his dogs. A number of works, the names of which are given below, are interesting, but hardly lend themselves to quotation.

The Cynegetica of Grattius (who has a special word for English Dogs) are perhaps too technical for general reading : there is a translation entitled Cynegeticon, A Poem on Hunting by Gratius the Faliscan, Englished by Christopher Wase in 1654. Varro's methodical account of the dog presents the same difficulties. Arrian's treatise on hunting has no very modern or good English translation. The elaborate, yet practical, manual of Xenophon, his Cynegeticus, can be read with advantage in Mr. Dakyns's translation (Macmillan). Harrison's Description of England in Shakespere's Jouth, edited from Holinshed's Chronicle, is of interest. Among the more modern books which are not mere practical treatises I may mention George R. Jesse's History of the British Dog, from ix 
which I have gained many hints as to where to look for material; C. A. Collins's entertaining Cruise upon Wheels; and the pathetic account of the life and death of poor Mathieu in M. Zola's La Joie de ITivre; Dr. John Brown's Rab and his Friends (Hore Subsecivec), an exquisite bit of work; Mrs. Ewing's Benjy in Beastland; and two wonderful studies of dogs by Mr. Alfred Olivant-Owd Bob, and Danny.

The frontispiece is reproduced by kind permission of Mr. Walter Jefferies, the breeder of Rodney Stone.

A few blank pagres are placed at the end of the volume which the reader can dedicate to the memory of his own canine friends. 


\section{TABLE OF CONTENTS}

PAGE

MAN'S ADVANTAGE . Cicero I

DOGS RACE FOR GLORY . . Plutarch I

THE DOG AS AVENGER . . , , 2

THE DOGS OF AlCiBIADES AND

XAÑTHPPUS . . . . . 4

THESMOPOLIS AND THE MAL-

TESE CUR . . . Lucian 5

TO HIS LOVE: TH.IT CON-

TROLDE HIS DOGGE FOR

FAWNing on HIR . Ceorge Turberville 7

DGGS RFASON . . . . . . . . 8

TO IHIS WIFE, FOR STRIKING

HER DOG . . . . Sir John Harrington xI

Of ENGI.ISIE DogGes . . Johannes Caius II

THE HuNTiNg DoG:S . . MT. Shakespeare I8

HOLNIDS OF SPARTA

KING IEAR'S DOGS . " . 20

Uion IIS SinNEIL Tr.scIF. Rolert Herrick 20 
IZAAK IIALTON'S I'RAISE OF

TIE I)OG .

THE OTTER HLNT .

MIITEFOOTE .

BEAR-BAITING

OF TIE INDUSTRIE AND

Fidelatie of DOGS. THEIR

ELOGIE OR MEMORABIE

PRAISE

A C.IT AND DOG LIFE.

- P. Camerarius

26

BLLL-BAITING

- Samuel Pepys

32

OF TIE DUGGE AND THE

PEECE OF FLESII

- 2 sop

OF THE OLD DUG AND IIS

MASTER

$$
\text { , , }
$$

OF THE MOLFE AND THE

DOGGE

OF THE ENvious DOGGE

The, lrish Greyhot ND.

TRUE'S EPITAPH .

THE LAST DYING IVORDS OF

BON.Y HECK, A FAMOUS

GREYHOLND IN THE SHIRE

OF Fifl:

- Hilliam Hamilton

BULL-BAITING

- John Houghton

$4^{2}$

TIIE HOUXDS.

William Somerville

UPON A DQG CALLED FŨDDLE,

TERNSPIT AT 'IIE I'OPINJAY,

IN NoRWICH 
O. THE COLLAR OF TIGER,

MrS. Dixgley's LAP-Dog . Jonathan Swift

ON ROYER, A LADY'S SPANIEL:

INstructions TO A PAINTER ,"

A.X Elegr ox A LAP-DOG . John Gay 60

THE MASTIFF . . . . . .

THE CLR, THE HORSE, AND

THE Silepherd's DOG . . .

THE COOK-IIAID, THE TURN-

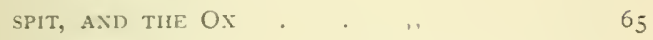

A Fragment : Of a Poem ox

Hu'NTiNG . . . Thomas Tickell 69

ARGL's . . Alexander Pope 72

EPIGRAM ENGRAVED ON THE

COLLAR OF A DOG WHICH I

GAFE TO His ROYAL High-

$\begin{array}{lllll}\text { NESS . . . . . . . } & 73\end{array}$

THE INDIAN AND HIS DUG . , ,

PART OF A LETTER TO MIR.

Hexry Cromwel . . ",

Blll-Baiting . . . M. Misson 77

Colrsing the Hake . James Thomson 79

Ux A DOG . . . . Hilliam Hamilton 79

BUFFON'S WORD FOR THE

Durs . . . . Georges L. L. Buffon 80

Fisirixg Dors . . Henry Fielding 8

Ax Apreciatros . . Horace Halpole 8 I

EPITAPII: ON A FAVUTRITE

LAP-DUG . . . Thomas Blackcock 8I xiii 
THE ExGish BULL, - DOG,

DUTCII MASTIFF, AND

QUAll, . . . Christopher Smart 82

AN EIEGY ON THE DEATH OF

A MAD DOG . . . Oliver Goldsmith 83

Tile IIntek Morning WVAk William Couper 84

THE DOG AND THE WATER-

ILY . . . . . . . . . . .

EPITAPII ON FOP, A DOG BL:-

LONGING TO LADY THROCK-

MORTON . . ,

A. EPITAFI: ON A PUINTER

BELONGING TO SIR JOHN

THROCHMORTON . . ,

ON a SPANiEl, CAlled BEAU, KILLING A YOUNG BIRD . , 89

BEAU'S REPLY . . . . . 90

THE PARSON, THE SQUIRE,

AND THE SPANiEL . . Peter Pindar 9I

AT THE B.IR . . . . Samuel J. Pratt 94

INSCRIPTION : ON A NEWFOUND-

LAND DOG * * . . Tord Eldon 98

TIIE DEALER AND CiekK . George Crabbe 99

TIIE TWA Dogs . . Robert Burns roI

ON THE DEATH OF A LAP-DOG,

NAMED ECHO . . . . . 103

MY HOGGIE . . . . . . . . 104

THE SHEPHERD AND IIS DOG William Lisle Bowles ro5

Man's Conqufst . . . Georges Cuvier 106 
BETH GÊLERT: OR, THE GRAVE OF THE GREYHouxD . . Robert II. Spencer IoS THE AUTHOR'S ADDRESS TO HIS ALLD DOG HECTOR . James Hogg I I I FIDELITY - $11 \mathrm{~m}$. Hordsworth I 16

IXCIDENT : CHARACTERISTIC OF
A FAvourite DOG
13

TRIBUTE : TO THE MEMORY OF

THE SAME DOG .

120

THE DANDY DiNMONTS . . Sir Walter Scott 122

THE DEATII OF KEELDAR . N 127

THE HLXT . . . . . .

HELTELLY: I805 . . . " 80 I35

O. THE DEATH OF A FAVOLR-

ITE OI.D SPANIEL . . Robert Southey I38

RECOGXITION . . . . . . . . 139

AN EPITAPII. . . Charles Lamb $1+1$

THAT YOU MUST LOVE ME

AND LOVE MY DOG . . ., $\quad 1+2$ To A SPAXIEL . . . HalterSavageLandor ift TOOLR HOLSE-DOG "CAPTAIN" ," It4 AXSWER TO A DUG'S INIITA-

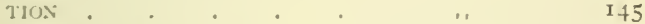

Conte A MON CHIEX - . Caroline B. Soulhey $1+5$

"BoAtsWain's" EpITAPII . Lord Byron I6o

TIIE BAgMan's Dug . . Thomas Ingoldsby 162

The Suciabi.f, ClR . . Thomas B. Macaulay I6 3

To Flush, My Dor . . Eliz. B. Browning I6.4

Flusil oR FAuxis. . . Eliz. B. Browning I6g 
DUGS J'REPARE TOR SLEEP

SIIFPHERH DOGS

OER DOGS

'I'HE: FusILIFR' DOG

JHRRI'S DOGS .

I'RAY
- Charles Daruin

PAGE

170

170

. John Brown

I 7 I

- Francis Doyle

I 79

- Charles Dickens

I 82

- Robert Browning

I 87

189

- George Eliot

190

I9I

- George Herbert

I 9 I

- Alfred J. Church 192

- Thomas Hardy 193

- Hm. J. Courthope 198

- Louis Robinson

$20 I$

- Frederick Langlridge $20 \mathrm{I}$ - S. H. Butcher and

Argos .

$$
\text { A. Lang }
$$

205

AN EPITAPII. . . William Watson

207

A Study in Contrasts.

,

207

The CARRIER DOG OF BERLiN Mary Armstrong 209

Choosing a Shepherd's DoG Alfred Olizant

210

TIIE KILLER AT BAY .

2 II

A RETRIEVER'S EPITAPH

Robert C. Iehmann

TO Rufus, A SPANIEL .

IN MEMORIAM

- Henry Willett

220

223

TO TIE MEMORY OF FAITHFul DOGS .

INDEX TO AUTHORS 

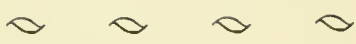

(From De Natura Deorum)

OGS watch for us faithfully: they love and
worship their masters: they hate strangers : their power of tracking by scent is extraordinary : great is their keenness in the chase:- what can all this mean but that they were made for man's advantage?

Cicero, translated by F. T. Richards.

Dogs Race for Glory

(From De Sollertia Animalium)

DOGS which hunt hares, if they kill them themselves, are delighted to tear the animal and swallow the blood; but if the hare gives out, as often happens, spends all his breath in running, 
and dies, they will not touch the body at all, but they stand wagging their tails, showing that they race for glory, not meat.

The Dog as Avenger $\propto \propto \propto$

WHEN Calvus the Roman was killed in the civil wars, no one was able to cut off his head until the murderers formed a ring and stabbed his dog, which showed fight for his body. King Pyrrhus, again, on a journey, fell in with a dog watching the body of a slain man, and, when he heard that it had stayed there two days without food and would not leave the body, he ordered his men to bury the body and bring the dog carefully away. A few days later he held a review, and the troops marched past the king, who had the dog with him, quite quiet. But when the dog saw the murderers of his master pass, he sprang out furiously against them, and barked at them several times, turning round to Pyrrhus, so that not only the king but all the bystanders looked on the men with suspicion. So they were arrested at once and examined, and, there being some little corroborative evidence, they confessed the murder and suffered for it. . . A man once broke into 
the temple of Esculapius at Athens, took whatever was portable of the gold and silver offerings, and, thinking himself unobserved, sneaked away. But the watchdog, Capparus, when none of the temple-keepers took notice of his barking, pursued the burglar in his flight. First, the man pelted him with stones, but he would not give up. When day came, he kept at a little distance, but followed with his eye on the man, and, when the latter threw him food, would not touch it. When the thief lay down, he spent the night by him; when he walked again, he got up and kept following. He fawned on any wayfarers he met, but kept barking at the thief. When the authorities, who were in pursuit, heard of this from the people who met them, and who described the colour and size of the dog, they pursued with yet more zeal, caught the man, and brought him back from Crommyon. The dog turned round and led the way, proud and delighted, evidently claiming that he had caught the temple-thief. So the people roted that he should be fed at the public expense and instructed the priests to take care of him. ... The following incident I saw inyself at Rome. There was a dog taking part in a play which had many characters and a complicated plot. He went through many bits of acting suitable to the supposed emotions and situations; and in particular, when the other characters tricd upon him a drug which was at 
narcotic but supposed to be deadly, he took the bread in which you were to understand the poison was mixed, and ate it, and a little while afterwards seemed to shiver and stagger and be stupefied. At last he stretched himself out and lay like a dead dog, and let them pull him and move him about as the needs of the play dictated. But when he got his cue from what was being said and done, he stirred, at first gently, as if waking from deep sleep, and lifted his head and looked round. Then, when they were surprised, he got up and went to the right man and gave him such a glad welcome that every one there, even the emperor (for this was in the theatre of Marcellus, and old Vespasian was present), felt for him. Ilutarch, translated by F. T. Richards.

The Dogs of Alcibiades and Xanthippus

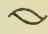

(From Lives of the Noble Grecians and kiomans)

(i) ACIBIADES had a marvelous fayer great dogge that cost him three score and tenne minas, and he cut of his taile that was his chief beawtie. When his friendes reproved him, and tolde him how every man blamed him for it ; he fell a laughing, and tolde them he had that he sought. For, sayeth he, I would have the 
Athenians rather prate upon that, then they should saye worse of me.

(ii) When time came that they were to departe the haven, and that all the cittie of Athens had taken sea:- There was a certen pittie that made mens harts to yerne, when they saw the poor dogges, beasts, and cattell ronne up and downe bleating, mowing, and howling out alowde after their masters, in token of sorowe, when they did imbarke. Amongest these, there goeth a straunge tale of Xanthippus dogge, who was Pericles father: which for sorowe his master had left him behinde him, dyd cast himself after into the sea, and swimming still by the galleys side wherein his master was, he helde on to the isle of Salamina, where so sone as the poore curre landed, his breath fayled him, and dyed presently.

Pluturch, translated by Sir Thomas North.

Thesmopolis and the Maltese Cur
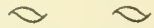

(From The Lamentable Lot of the Leamed atho engage themselves in noble and opulent Families)

MUST relate to you a strange adventure that
befell the celebrated Thesmopolis, and indeed may equally befall any other. He was living at the time in the house of a rich and elegant matron. 
Being once to attend on her into the country . . the noble dame, going to enter the vehicle, called him to her. Dear Thesmopolis, said she, I have a great favour to ask of you - you will oblige me much-it is indeed presuming beyond measure - but I know you will not deny my request, nor put me off with delays.-You may easily suppose that his answer was, that the noble lady had but to lay her commands upon him.I would not desire it of you, continued the lady, if I was not persuaded that you have the kindest heart in the world, and are a man on whose care and affection I can entircly rely. Would you be so good as to take my Myrrhina into the carriage with you, and see that she wants for nothing? She is with pup, the poor thing! and she is near her time. I cannot trust my people; the perverse, unmannerly wretches pay no attention on the road even to myself, how can I expect they will have care of the poor animal! What less could Thesmopolis do, on being petitioned by such a great lady in such a heart-rending tone, and I could almost add with tears, than promise her all she desired? Meantime it was impossible to behold anything more ridiculous than how the dog with its little snout peeped out from beneath his mantle just below his long beard, and I suppose now and then bedewed his lap (though Thesmopolis did not boast of that circumstance), 
yelping in a small harsh tone, as is the way with these maltese curs, and licking the bushy chin of the grave philosopher. The fop who sat next him said afterwards at table, Against Thesmopolis I have nothing to object, except that he has recently from a stoic become a cynic; it has been told me for certain that the little bitch was brought to bed in his mantle.

Such are the cruel insults that are put upon the learned who live with the great.

Lucian, translated by $W$. Tooke.

To His Love: That Controlde his Dogge for Fawning on Hir
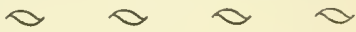

IN deede (my Deare) you wrong my Dog in this And shew your selfe to be of crabbed kinde,

That will not let my fawning whelp to kisse

You first, that fain would shew hys Maisters minde :

A Mastife were more fit for such a one, That can not let hir Lovers dog alone.

He in his kinde for mee did seeme to sue, That earst did stande so highly in your grace, His Maisters minde the wittie Spanell knewe, And thought his woonted Mistresse was in place: 
But now at last (good faith) I plainely see That Dogs more wise than women friendly bee.

Wherefore since you so cruelly entreate My whelp, not forcing of his fawning cheere, You shew your selfe with pride to be repleate, And to your Friend your nature doth appecre: The Proverbe olde is verifide in you, Love mee and love my Dog, and so adue.

Both I and hee that siely Beast sustaine For loving well and bearing faithfull harts, Despitous cheeks, and rigorous disdaine, Where both hath well deserved for our parts, For Friendship I, for offred service hee, And yet thou neyther loouste the Dog nor mee.

George Turberville.

Dogs Reason
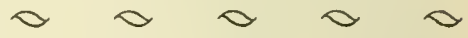

(From Montaigne's Essayes)

CHRYSIPPUS, albeit in other things as disdainfull a judge of the condition of beasts, as any other Philosopher, considering the earnest movings of the dog, who comming into a path, that led three severall wayes, in search or quest of his Master, whom he had lost, or in pursuit of some prey, that hath escaped him, goeth scenting 
first one way, and then another, and having assured himself of two, because he findeth not the tracke of what he hunteth for, without nore adoe, fureously betakes himselfe to the third; he is enforced to confesse, that such a dog must necessarily discourse thus with himselfe, "I have followed my Masters footing hitherto, hee must of necessity passe by one of these three wayes; it is neither this nor that, then consequently hee is gone this other." And by this conclusion or discourse assuring himselfe, comming to the third path, hee useth his sense no more, nor sounds it any longer, but by the power of reason suffers himselfe violently to be caried through it. This meere logicall tricke, and this use of divided and conjoyned propositions, and of the sufficient numbring of parts: Is it not as good, that the dog knew it by himselfe, as by Trapezuntius his logicke? Yet are not beasts altogether unapt to be instructed after our manner. We teach Blackebirds, Starlins, Ravens, Piots, and Parots to chat; and that facilitie we perceive in them, to lend us their voyce so supple, and their wind so tractable, that so wee may frame and bring it to a certaine number of letters and silables, witnesseth, they have a kind of inward reason, which makes them so docile, and willing to learne. I thinke every man is cloied and wearied, with seeing so many apish and mimmike trickes, that juglers teach 
their Dogges, as the dances, where they misse not one cadence of the sounds or notes they heare : Marke but the divers turnings, and severall kinds of motions, which by the commandement of their bare words they make them performe: But I wonder not a little at the effect, which is ordinary among us; and that is, the dogs which blind men use, both in Citie and Country: I have observed how sodainly they will stop when they come before some doores, where they are wont to receive alms; how carefully they will avoyd the shocke of Carts and Coaches, even when they have roome enough to passe by them selves. I have scene some, going along a Towne-ditch, leave a plaine and even path, and take a worse, that so they might draw their Master from the ditch. How could a man make the dog conceive, his charge was only to looke to his masters safetie, and for his service to despise his owne commoditie and good? And how should he have the knowledge, that such a path would be broade inough for him, but not for a blind man? Can all this be conceived without reason?

Montuigne, translated by Florio. 
To his Wife, for striking her Dog

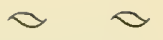

YOUR little Dog that bark'd as I came by, I strake by hap so hard, I made him cry, And straight you put your finger in your eye, And lowring sate, and ask'd the reason why. Love me and love my Dog, thou didst reply: Love, as both should be lov'd, I will, said I, And seal'd it with a kisse. Then by and by Clear'd were the clouds of thy faire frowning skie. Thus small events great masteries may try.

For I by this do at their meaning guesse, That beat a Whelpe afore a Lyonesse! Sir John Harrington.

Of Englishe Dogges
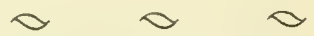

(From A Short Treatise verittch in Latine by Johannes Cains, and newly drazone into Englishe by Abrahan Fleming, Student. Imprinted at London in 1576)

$\mathrm{B}^{\mathrm{UT}}$ to returne to our shepherds dogge. This
dogge either at the hearing of his masters voyce, or at the wagging and whisteling in his fist, or at his shrill and horse hissing bringeth the wandring weathers and straying sheepe, into the selfe same place where his masters will and wishe is to have them, whereby the shepherd reapeth this benefite, namely, that with little labour and no 
toyle or moving of his feete he may rule and guide his flocke, according to his owne desire, either to have them go forward, or to stand still, or to drawe backward, or to turne this way, or to take that way. For it is not in Englande, as it is in Fraunce, as it is in Flaunders, as it is in Syria, as it is in Tartaria, where the sheepe follow the shepherd, for hecre in our country the shepherd followeth the sheepe. And sometimes the straying sheepe, when no dogge runneth before them, nor goeth about beside them, gather themselves together in a flocke, when they heere the shepherd whistle in his fist, for feare of the Dogge (as I imagine) remembring this (if unreasonable creatures may be reported to have memory) that the Dogge commonly runneth out at his masters warrant which is his whistle. This have we oftentimes diligently marcked in taking our journey from towne to towne, when wee have hrd a shepherd whistle we have rayned in our horse and stode styll a space, to see the profe and triall of this matter. Furthermore with this clogge doth the shepherd take sheepe for ye slaughter, and to be healed if they be sicke, no hurt nor hame in the world done to the simple creature.

This dogge is also called in Latine Canis Mandatarius a Dogge messinger or Carrier.

Upon substanciall consideration, because at his masters voyce and commaundement, he carrieth 
letters from place to place, wrapped up cunningly in his lether collar, fastened thereto, or sowed close therein, who, least he should be hindered in his passage useth these helpes very skilfully, namely resistaunce in fighting if he be not overmatched, or else swiftnesse and readinesse in running away, if he be unable to buckle with the dogge that would faine have a snatch at his skinne.

This kinde of dogge is called in like maner Canis Sarcinarius in Latine, and may aptly be englished a Tynckers Curre.

Because with marveilous pacience they beare bigge budgettes fraught with tynckers toles, and mettail meete to mend kettels, porrige pottes, skellets, and chafers, and other such like trumpery requisite for their occupacion and loytering trade, easing him of a great burthen which otherwise he himselfe should carry upon his shoulders, which condition hath challenged unto them the foresaid name. I3esides the qualities which we have already recounted, this kind of dogges hath this principall property ingrafted in them, that they love their masters liberally, and hate straungers despightfully, whercupon it followeth that they are to their masters, in traveiling a singuler safgard, 
defending them forceably from the invasion of villons and theefes, preserving their lyfes from losse, and their health from hassard, theyr fleshe from hacking and hewing and such like desperate daungers. For which consideration they are meritoriously tearmed

In Latine Canes defensores defending dogges in our mother tounge.

If it chaunce that the master be oppressed, either by a multitude, or by the greater violence and be so beaten downe that he lye groveling on the grounde, (it is proved true by experience) that this Dogge forsaketh not his master, no not when he is starcke deade: But induring the force of famishment and the outragious tempestes of the weather, most vigilantly watcheth and carefully kecpeth the deade carkasse many dayes, indevouring, furthermore, to kill the murtherer of his master, if he may get any advantage. Or else by barcking, by howling, by furious jarring, snarring, and such like meanes betrayeth the malefactour as desirous to have the death of his aforesayde master rigorouslye revenged.

In fyers also which fortune in the silence and dead time of the night, or in stormy weather of the sayde scason, the older dogges barcke, ball, 
howle, and yell (yea not withstandy'ng they bee roughly rated), neyther will they stay their tounges till the housholde servaunts, awake, ryse, searche, and see the burning of the fyre, which beyng perceaved they use voluntary silence, and cease from yolping. This hath bene, and is founde true by tryall, in sundry partes of England. There was no faynting faith in that Dogge, which when his Master by a mischaunce in hunting stumbled and fell toppling downe a deepe dytche beyng unable to recover of himselfe, the Dogge signifying his masters mishappe, reskue came, and he was hayled up by a rope, whom the Dogge seeyng almost drawne up to the edge of the dytche, cheerefully saluted, leaping and skipping upon his master as though he woulde have imbraced hym, beyng glad of his presence, whose longer absence he was lothe to lacke. Some Dogges there be, which will not suffer fyery coales to lye skattered about the hearthe, but with their pawes wil rake up the burny'ng coales, musyng and studying fyrst with themselves howe it myght conveniently be done. And if so bee that the coales cast too great a heate then will they burry them in ashes and so remove them forwarde to a fyt place wyth theyr noses. Other Dogges bee there which exequte the office of a farmer in the nyghte tyme. For when his master goeth to bedde to take his naturall sleepe. And when, 
A hundred barres of brasse and yron boltes, Make all things safe from startes and from revoltes.

When Janus keepes the gate with Argos eye,

That daungers none approch, ne mischiefes nye.

As Virgill vaunteth in his verses, Then if his master byddeth him go abroade, he lingereth not, but raungeth over all his lands lying there about, more diligently, I wys, than any farmer himselfe. And if he finde anything their that is straunge and pertaining to other persons besides his master, whether it be man, woman, or beast, he driveth them out of the ground, not medling with any thing which doth belong to the possession and use of his master. But how much faythfulnes, so much diversitie there is in their natures,

(Which barcke only with free and open For there throats but will not bite.

be some, Which doe both barcke and byte, (Which bite bitterly before they barcke.

The first are not greatly to be feared, because they themselves are fearefull, and fearefull dogges (as the proverbe importeth) barcke most vehemently.

The second are dangerous, it is wisedome to take heede of them because they sounde, as it were, an Alarum of an afterclappe, and these dogges must not be over much moved or provoked, for then they take on as outragiously as if they were madde, watching to set the point of their 16 
teeth in the fleshe. And these kind of dogges are fearce and eager by nature.

The thirde are deadly, for they flye upon a man, without utteraunce of voyce, snatch at hin, and catch him by the throate, and most cruelly byte out colloppes of fleashe. Feare these kind of Curres, (if thou be wise and circumspect about thine old safetie) for they be stoute and stubberne dogges, and set upon a man at a sudden unwares. By these signes and tokens, by these notes and argumentes, our men discerne the cowardly curre from the couragious dogge, the bolde from the fearcfull, the butcherly from the gentle and tractable. Moreover they conjecture that a whelpe of an yll kinde is not worthe the keeping and that no dogge can serve the sundry uses of men so aptly and so convenientlyas this sort of whom we have so largely written already. For if any be disposed to drawe the above named services into a table, what man more clearely, and with more vehemency of voyce giveth warning eyther of a wastefull beast, or of a spoiling theefe then this? who by his barcking (as good as a burning beacon) foreshoweth hassards at hand ? what maner of beast stronger? what servant to his master more loving? what companion more trustie? what watchman inore vigilant? what revenger more constant? what messinger more speedic? what water bearer more painfull? finaily what pack horse more patient?...

Johannes Caius.

C 


\section{The Hunting Dogs}
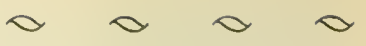

(From The Taming of the Shrew)

L ORD. Huntsman, I charge thee, tender well my hounds :

Brach Merriman, the poor cur is emboss'd;

And couple Clowder with the deep-mouth'd brach. Saw'st thou not, boy, how Silver made it good At the hedge-corner, in the coldest fault?

I would not lose the dog for twenty pound.

First Huntsman. Why, Belman is as good as he, my lord;

He cried upon it at the merest loss And twice to-day pick'd out the dullest scent:

Trust me, I take him for the better dog.

Lord. Thou art a fool: if Echo were as fleet, I would esteem him worth a dozen such.

But sup them well and look unto them all: To-morrow I entend to hunt again.

Willian Shakespeare.

Hounds of Sparta
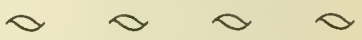

(From Midsummer Night's Dream)

THESEUS. Go, one of you, find out the Forester;

For now our observation is perform'd ; And since we have the vaward of the day, 
My love shall hear the musick of my hounds :

Let them uncouple in the Western valley, go ;

Despatch, I say, and find the Forester.

We will, fair Queen, up to the Mountain's top,

And mark the musical confusion

Of hounds and echo in conjunction.

Hippolyta. 1 was with Hercules and Cadmus once,

When in a wood of Crete they bay'd the boar

With hounds of Sparta: never did I hear

Such gallant chiding; for, besides the groves,

The skies, the fountains, every region near,

Seem'd all one mutual cry: I never heard

So musical a discord, such sweet thunder.

Theseus. My hounds are bred out of the Spartan kind,

So flew'd, so sanded; and their heads are hung With ears that sweep away the morning dew ;

Crook-knee'd, and dew-lapt like Thessalian Bulls; Slow in pursuit, but match'd in mouth like bells, Each under each. A cry more tuneable

Was never holla'd to, nor cheer'd with horn, In Crete, in Sparta, nor in Thessaly: Judge, when you hear.

William Shakespeare. 
King Lear's Dogs
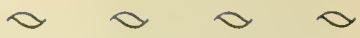

(From Kins Lear, Act III. Scene vi.)

KING LEAR. The little dogs and all,

Tray, Blanch, and Sweet-heart, see, they bark at me.

Edgar: Tom will throw his head at them.Avaunt, you curs!

Be thy mouth or black or white,

Tooth that poisons if it bite;

Mastiff, grey-hound, mongrel grim,

Hound or spaniel, brach or lym ;

Or bobtail tike, or trundle tail,

Tom will make them weep and wail :

For, with throwing thus my head,

Dogs leap the hatch, and all are fled.

William Shakespeare.

Upon his Spaniell Tracie
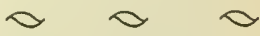

Now thou art dead, no eye shall ever see,

For shape and service Spaniell like to thee.

This shall my love doe, give thy sad death one Teare, that deserves of me a million.

Robert Herrick. 
Izaak Walton's Praise of the Dog

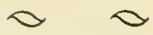
(From The Compleat Angler)

$A$ ND for the dogs that we use, who can commend their excellency to that height which they deserve? How perfect is the Hound at smelling, who never leaves or forsakes his first scent, but follows it through so many changes and varieties of other scents, even over and in the water, and into the earth! What music doth a pack of dogs then make to any man, whose heart and ears are so happy as to be set to the tune of such instruments! How will a right Greyhound fix his eye on the best Buck in a herd, single him out, and follow him, and him only, through a whole herd of rascal game, and still know and then kill him! For my Hounds, I know the language of them, and they know the language and meaning of one another, as perfectly as we know the voices of those with whom we discourse daily.

The Otter Hunt
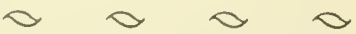

VENATOR. My friend Piscator, you have kept time with my thoughts; for the sun is just rising, and I myself just now come to this place, and 
the dogs have just now put down an Otter. Look down at the bottom of the hill there in that meadow, checkered with water-lilies and ladysmocks; therc you may see what work they make. Look! look! you may see all busy, men and dogs, dogs and men, all busy.

Piscator. Sir, I am right glad to meet you, and glad to have so fair an entrance into this day's sport, and glad to see so many dogs, and more men all in pursuit of the Otter. Let's compliment no longer, but join unto them. Come, honest Venator, let's be gone, let us make haste; I long to be doing: no reasonable hedge or ditch shall hold me.

Venator. Gentleman Huntsman, where found you this Otter?

Huntsman. Marry, Sir, we found her a mile from this place, a-fishing: she has this morning eaten the greater part of this Trout; she has only left thus much of it, as you see, and was fishing for more.

When we came, we found her just at it; but we were here very early, we were here an hour before sunrise, and have given her no rest since we came; sure she will hardly escape all these dogs and men. I am to have the skin if we kill her.

Huntsman. And thus much for my knowledge 
of the Otter, which you may now see above water at vent, and the dogs close with him; I now see he will not last long ; follow, therefore, my masters, follow, for Sweetlips was like to have him at this last vent.

Venator. Oh me! all the horse are got over the river. What shall we do now? shall we follow them over the water?

Huntsman. No, Sir, no, be not so eager: stay a little and follow me, for both they and the dogs will be suddenly on this side again, I warrant you; and the Otter too, it may be. Now have at him with Kilbuck, for he vents again.

Venator. Marry, so he does, for look, he vents in that corner. Now, now Kingwood has him: now he's gone again, and has bit the poor dog. Now Sweetlips has her; hold her, Sweetlips! Now all the dogs have her, some above and some under water; but now, now she's tired, and past losing : come, bring her to me, Sweetlips.

Izaak Walton. 
Whitefoote
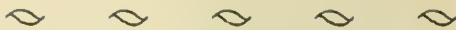

(From Poemes Lyrick and Pastorall)

(From the Sercnth Eglog)

I IKE to the cur with anger welnear wood, 1. Who makes his kennell in the oxes stall, And snarleth when he seeth him take his food: And yet his chaps can chew no hay at all.

(From the Tenth Eiglog)

He call'd his dog (that sometime had the praise), Whitefoote, well known to all that kept the plaine That many a wolf had werried in his days, A better cur, there never followed swain: Which, though as he his master's sorrows knew, Wag'd his cut tayle, his wretched plight to rue.

Poor cur, quoth he, and him therewith did stroke, Go to our coat, and there thyselfe repose, Thou with thine age, my hart with sorrow broke, Be gone ere death my restles eyes do close, The time is come, thou must thy master leave, Who the vile world shall never more deceive.

Michael Drayton. 
(From A Letter: whearin, Part of the Entertainment untoo the Queenz Majesty, at Killingwoorth Castle in Warwick Sheer, in this Soomerz Progrest 1575 , is signified: From a freend office attendant in the Coourt [R. Laneham], unto his freend a Citizen and Mlerchaunt of London)

THURSDAY, the foourteenth of this July, and the syxth day of her Majestyez cumming, a great sort of Bandogs whear thear tyed in the utter Coourt, and thyrteen Bearz in the inner. . . . The Bearz wear brought foorth intoo the Coourt, the Dogs set too them, too argu the points eeven face too face ; they had learn'd counsel also a both parts. Very feers both ton and toother and cager in argument: If the Dog in pleadyng woold pluk the Bear by the throte, the Bear with travers woould claw him again by the scalp; Confess an a list, but avoyd a coould not that waz bound too the bar. ... Therefore thus with fending and prooving, with plucking and tugging, skratting and byting, by plain tooth and nayll a to side and toother, such expens of blood and leather waz thear between them, as a month's licking, I ween, will not recoover : and yet remain as far out az ever they wear. It was a sport very pleazaunt of theeze beastz; to see the Bear with his pink nyez leering after his enmiez approch, the nimblness and wayt 
of the Dog too take his avauntage, and the fors and experiens of the Bear agayn to avoyd the assauts: If he wear bitten in one place, hoow he woold pynch in an oother too get free: that if he wear taken onez, then what shyft with byting with clawying, with roring tossing and tumbling he woold woork too wynde hym self from them: And when he was lose, to shake hiz earz twyse or thryse with the blud and the slaver aboout his fiznamy, waz a matter of a goodly releef.

Of the Industrie and Fidelitie of Dogs. Their Elogie or Memorable Praise

(From the "Living Librarie." Written in Latin by P. Camerarius, and done into English by John Molle, Esquire, in 1621)

THERE he found many discourses almost incredible in histories, concerning the industrie and fidelitie of dogs. Dio reporteth notable things of the fidelity of Sabinus his dog. Pierius recounteth out of ancient Authours, that Minerva lliada had a temple in Daulis, wherein certaine dogs were kept, which never shewed themselves gentle to any, and to be plaied withall, but to the Greekes; for against the Barbarians, they would ever be barking and still troubling and biting them. 26 
Plinie saith the like of Diomedes his birds, which were never seen any where else but in a certain Isle upon the coast of Apulia, famous for the sepulchre of Diomedes, and for a chappell dedicated unto him. These birds by reason of their cryings and croakings, bred great annoiance to the Barbarians that landed there: but they fluttered and rejoyced at the Grecians. The same Pierius reportheth ancient Authors to have written, that neere to Mount-Gibell in Sicilia there was a temple builded to Vulcan, the groave whereof was guarded by dogs (as M. Marlianus also reportest, that in old Rome before Vulcans chappell, in the Flaminian Cirque, were certaine dogs that would never barke but against Church-robbers) which would run with great fawning to meet the good and devout pilgrims; but if any that were villanous and dishonest came thither, they were miserably torne in pieces by those dogs. Thomas Fasel writeth, that the Pagans held these actions for so many miracles: but we make account (saith he) they were the deceits of Sathan. The same saith, That at this day there is not seen any trace or token of this temple, and a man cannot say in what part of the Mountaine it was. Carlius Rhodiginus and Alexander of Alexandia write thereof at large.

The faithfulnesse of a dog, lath beene cause that many have chosen to trust their lives with 
that beast, and to commit themselves to the good of him, rather than of reasonable men.

A courtier envying the credit of a certaine friend of his, or carried away with some other malice came suddenly upon him, and killed him, and after buried him in a place besides the way. The partie slaine had at the same time a hound with him, who lay a long while upon his master's grave. Hunger for that time overcomming love, he returnes home, and being seene without his Master by some other friends, who thought the dog had been straied from him, they bad that some meat should be given him. Having let downe a few morcels, he returnes to the grave, which course he continued so often, that the friends of the dead began to suspect, and at last belecved that the dog sought for his Master: They follow him, and comming to the place where the earth was cast up, dig into it, find the bodie, take it away, and cause it to be buried in another place. The solemnities ended, the dog keepes with them whom he had lead to this discoverie. A good while after, the murtherer comes againe to the court; the dog knowes him, and begins to run at him with great cries, and so earnestly pursueth his point upon him, that suspition begins to enter into the minds of a great many, that there was some evill in the man. The dog continuing still to vex him, the king was at 28 
last advertizied of the case, who commanded that the man should be straitly examined touching the fact. He affirmeth himselfe innocent: the dog, when the murtherer denied that he knew what was become of the dogs master, nerer left barking and bawling; in so much as all that were present tooke the same as a disproofe, that the dog made against him. Well, the matter proceeded so far, that the king ordered it should be decided by a combat betweene the man and the dog. To make short, the dog had the day: and the combat is painted and finely set forth in the hall of a certaine castle in France; and the worke wearing out with age hath sometimes beene renewed by commandement from the king. It deserveth (saith the Lord de la Scale) to be set forth in pictures of brasse, that it may never perish. ${ }^{1}$

The marks of a good dog, and of a gentle kind, are these that follow. He must be fleshic, great, of a large forehead, and full of appearing veines, eyes blacke and flaming, eares thin and long, the necke long, the breast bearing out, the shoulders broad, the thighs high, the flanks set forward, the legs equally distant, the haire small and thicke, the colour mingled. Belisarius, duke of Merito, discourseth amply thereof, to content the curious

1 The dog of Montargis. 
Reader. And Suidas in his Recuels representeth all sorts of dogs: Some are good for the hunting of little beasts, to sent and discover them, others to set upon great beasts, others to guard houses and parks: others are cushin-dogs, and for pleasure. But to close up this Meditation, we wil adde hereunto that which James Micyllus, a leared Poet hath written in praise of a dog, in good Latin verses, expressed thus in our tongue :-

Of any beast, none is more faithful found,

Nor yeelds more pastime in house, plaine or woods,

Nor keeps his masters person, or his goods

With greater care, than doth the dog or hound.

Commaund: he thee obeyes most readily.

Strike him: he whines and falls down at thy feet.

Call hin: he leaves his game and comes to thee

With wagging taile, offring his service meeke.

In Summers heat he followes by thy pace:

In winters cold he never leaveth thee:

In mountaines he by thee close doth trace;

In all thy feares and dangers true is he.

Thy friends he loves; and in thy presence lives

By day : by night he watcheth faithfully

That thou in peace may sleepe: he never gives

Good entertainment to thine enemie. 
Course, hunt, in hills, in valleyes, or in plaines; Hee joyes to runne and stretch out every lim:

To please but thee, he spareth for no paines:

His hurt (for thee) is greatest good to him. Sometimes he doth present thee with a Hare,

Sometimes he hunts the Stag, the Fox, the Boare,

Another time he baits the Bull and Beare, And all to make thee sport, and for no more. If so thou wilt, a Collar he will weare; And when thou list to take it off againe, Unto thy feet hee coucheth downe most faire, As if thy will were all his good and gaine. In fields abroad he lookes unto thy flockes, Keeping them safe from Wolves and other beasts :

And oftentimes hee beares away the knocks Of some odde thiefe that many a fold infests. And as he is the faithfull bodies guard, So is he good within a fort or hold Against a quicke surprise, to watch and ward ; And all his hire is bread mustie and old. Canst thou then such a creature hate and spurne? Or barre him from such poore and simple food? Being so fit and faithfull for thy turne, As no beast else can doe thec halfe such good? I. Camerarius. 


\section{A Cat and Dog Life}

(From I'epy's' Diary)

Sippember $\mathbf{x} \mathbf{x}, \mathbf{1 6 6}$

TO Dr. IVilliams, who did carry me into his garden, where he hath abundance of grapes : and he did show me how a dog that he hath do kill all the cats that come thither to kill his pigeons, and do afterwards bury them; and do it with so much care that they slall be quite covered; that if the tip of the tail hangs out, he will take up the cat again, and dig the hole deeper, which is very strange; and he tells me, that he do belicve he hath killed above roo cats.

Bull-Baiting
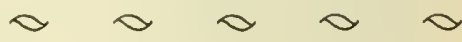

August I4, I 666

A FTER dinner with my wife and Mercer to A the Beare Garden; where I have not been, I think, of many years, and saw some good sport of the bull's tossing of the dogs: one into the very boxes. But it is a very rude and nasty pleasure. We had a great many hectors in the same box with us, and one very fine went into 
the pit, and played his dog for a wager, which was a strange sport for a gentleman.

Samuel Pepys.

Of the Dogge and the Peece of Flesh

(From The Fables of Essop, in English. Imprinted at London for Andrew Hebb, in I634)

$\mathrm{H}^{\mathrm{E}}$ that coveteth other mens goods, hee oft loseth his owne, whereof Esop rehearseth this Fable. In time past there was a dog which went over a briclge, and held in his mouth a peece of flesh, and as he passed over the bridge, he perceived the shadow of his owne selfe, and of his peece of flesh within the water: and he weening that it had beene another peece of flesh, forthwith thought to have taken it: and as he opened his mouth, the flesh fell into the water, and thus he lost it. Right so is it with many a one, for when they thinke to rob other, they leeve that which they have of their owne.

Of the old Dog and his Master

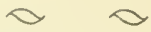

MEN ought not to dispraise the ancient, nor to put them backe, for if thou be young, thou oughtest to desire greatly to come to be old, D 
also thou oughtest to praise the acts or deeds, which they have done in their young age, whereof Esop rehearseth to us such a fable. There was a Lord which had a dog, the which in his youth had beene of good kind: as namcly to chase and hunt, and to have great lust to run and take the wild beasts. And when this dogge was come to old age, and that he could no more run, it hapned once that he let goe and escaped from him a Hare, wherefore his Master was wroth and angry, and in great rage began to beat him. Then said the Dogge unto him, My Master, for good service thou yecldest me evil: for in my young age and prosperity, I served thee right well, and now that I am come to nuy old age, thou hatest and setteth me backe. Remember, I pray thee how that in my young age I was strong and lustie, and now when I am old and feeble, thou settest nothing by me. Therefore, who so doth any good in his youth, in his old age he shall not continue in the vertues which he possessed in his youth.

Of the Wolfe and the Dogge $\propto$

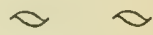

I IBERTIE or freedome is a pleasant thing, L whereof Esop rehearseth a fable. A wolfe and a dogge by chance met together. And the 
Wolfe demanded of the Dogge how he came to be so fat? The Dogge answered: I have well kept my Lords house, and have barked at the theeves which came into my masters house: Wherefore ne and his men give me plenty of meat, whereof I am faire and fat. And the Wolfe said to him, It is well said my brother, and surely seeing thou farest there so well, I have a very great desire to dwell with thee, to the intent that thou and I may both dine together. Well, said the Dogge, come thou with me, if thou wilt be at thy ease as I am and have no dread, nor doubt of any thing.

Then the Wolfe went with Dogge, and as they went by the way, the Wolfe beheld the Dogs necke which was all bare of haire, and demanded of the Dogge and said, My brother, why is thy necke so bare? and the Dogge said, It is by reason of my great collar of iron, to the which daily I am fastened, and at night I am unbound for to keepe the house the better: then said the Wolfe to the Dogge, I that am in liberty, will not be put in such subjection to be bound and need not, and therefore if thou beest accustomed thereto and liketh well of it, continue so still and spare not, for I will not leave my libertie to fill my body. By which we learne, that liberty is more to bee regarded than wealth. 
NO man ought to have envy at other mens good fortune, as appeareth by this fable of an envious dogge which went into a stable of Oxen, because that they should not enter in for to eat of the hay. And then the Oxen said unto him, Thou are evill and perverse to have envy of other mens good, the which is to us needfull and profitable, for thy kind is not to eat hay. And thus he did of a great bone which he hell in his mouth, he would not leave it, becausc of the envy of another dogge being hard by. This fable therefore teacheth us, that it behoaveth every one to keep himselfe from the company of an envious person.

The Irish Greyhound

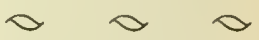

$\mathrm{B}^{\text {EHOLD this Creature's Form and State; }}$

Which Nature therefore did create,

That to the World might be exprest

What Mien there can be in a Beast;

And that we in this Shape may find

A Lion of another Kind.

For this Heroick Beast does seem

In Majesty to Rival him. 
And yet vouchsafes, to Man, to shew Both Service and Submission too. From whence we this Distinction have, That Beast is Fierce, but this is Brave. This Dog hath so himself subdu'd, That Hunger cannot make him rude : And his Behaviour does confess True Courage dwells with Gentleness.

With sternest Wolves he dares engage, And acts on them successful Rage. Yet too much Courtesie may chance To put him out of Countenance.

When in his Opposer's Blood, Fortune hath made his Vertue good; This Creature from an Act so brave Grows not more Sullen, but more Grave. Man's Guard he would be, not his Sport, Believing he hath ventur'd for't; But yet no Blood, or shed, or spent, Can ever make him insolent.

Few Men, of him, to do great Things have learn'd,

And when th' are done to be so unconcern'd. Katherine Philips-" The Matchless Orinda." 
'True's Epitaph

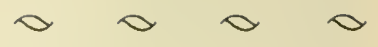

I F wit or honesty could save

1 Our mouldering ashes from the grave, 'This stone had still remain'd unmark'd, I still writ prose, True still have bark'd.

But envious fate has claim'd its due, Here lies the mortal part of True. His deathless virtues must survive, To better us that are alive.

His prudence and his wit were seen

In that, from Mary's grace and mien, He own'd the power, and lov'd the queen.

By long obedience he confess'd That serving her was to be bless'd.Ve murmurers, let True evince That men are beasts, and dogs have sense!

His faith and truth all Whitehall knows, He ne'er could fawn or flatter those Whom he believed were Mary's foes : Ne'er skulk'd from whence his sovereign led him, Or snarl'd against the hand that fed him.Read this, ye statesmen now in favour, And mend your own, by True's behaviour: 
The Last Dying Words of Bonny Heck, a famous Greyhound in the Shire of Fife $\propto$

A LAS, alas, quo' bonny Heck,

A On former days when I reflect:

I was a Dog much in respect

For doughty Deed:

But now I must hing by the Neck

Without Remeed.

O fy, Sirs, for black burning Shame, Ye'll bring a Blunder on your Name!

Pray tell me wherein I'm to blame?

Is't in Effect,

Because I'm Cripple, Auld and Lame?

Quo' bonny Heck.

What great Feats I have done my Sell

Within Clink of Kilrenny Bell,

When I was Souple, Young, and Fell,

But Fear or Dread:

John Ness and Paterson can tell,

Whose Hearts may bleid.

They'll witness that I was the Vier

Of all the Dogs within the shire;

l'd run all Day, and never tyre:

But now my Neck,

It must be stretched for my Hyre,

Quo' bonny Heck. 
How nimbly could I turn the Hair, Then serve myself, that was right fair ! For still it was my constant Care The Van to lead:

Now, what could sary Heck do mar, Syne kill her dead?

At the K'ing's-muir and Kelly-laze, Where good stout Hairs gang fast awa, So cliverly I did it Claw, With Pith and Speed,

I bore the Bell before them a' As clear's a Beid.

I ran alike on a' kind Grounds, Yea, in the midst of Ardry Whines, I grip't the Nackings be the Bunns, Or be the Neck;

Where nathing could slay them but Guns, Save bonny Heck.

I wily, witty was, and Gash, With my auld felni packy Pash Nae man might anes buy me for Cash In some respect. Are they not then confounded Rash, That hangs poor Heck?

I was a bardy Tyke and bauld; 'Tho' my beard's grey, I'm not so auld : 
Can any Man to me unfauld, What is the Feid,

To stane me ere I be well Cauld?

A cruel Deed :

Now Honesty was ay my Drift, An innocent and harmless Shift, A Kaill-pot-lid gently to lift, Or Amby-Sneck.

Shame fa the Chafts dare call that Thift!

Quo' bonny Heck.

So well's I cou'd play Hocus Pocus, And of the Servants mack Jodocus, And this I did in very Locus

Throw their Neglect.

And was not this a Merry Jocus?

Quo' bonny Heck.

But now, good Sirs, this day is lost, The best Dog in the East-Nook Coast,

For never ane durst Brag nor Boast Me, for their Neck;

But now I must yicld up the Ghost, Quo' bonny Heck.

And put a period to my Talking, For I'm unto my Exit making: Sirs, ye may a' gae to the Hawking, And there Reflect, 
le'll ne'er get sick a Dog for Makin As bonny Heck.

But if my P'uppies ance were ready, Which 1 gat on a bonny Lady:

They'Il be baith Cliver, Keen, and Beddy,

And ne'er Neglect

To Clink in like their ancient Deddy,

The famous Heck.

William Hamilton.

Bull-Baiting $\propto \propto \propto \propto$

(From A Collection for Improvement of Husbandry and Trade)

WHEN he is at fell growth, and strong, he is often Baited almost to death; for that great Exercise makes his Flesh more tender; and so if eaten in good time (before putrefaction, which he is more subject to than if not boiled) he is tolerable good Meat, altho' very red.

Some keep him on purpose for the sport of 13aiting, cutting off the Tips of his Horns, and with Pitch, Tow, and such like matter, fasten upon them the great Horns of Oxen, with their Tips cut off, and covered with leather least they should hurt the Dogs.

Because these Papers go into several other 42 
Countries, I'll say something on the Manner of Baiting the Bull, which is, by having a Collar about his Neck, fastened to a thick Rope about Three, Four, or Five Yards long, hung to a Hook, so fastened to a stake that it will turn round; with this the Bull circulates to watch his Enemy; which is a Mastiff Dog (commonly used to the Sport) with a short Nose, that his teeth may take the better hold: This Dog, if right, will creep upon his Belly that he may, if possible, get the Bull by the Nose; which the Bull as carefully strives to defend, by laying it close to the Ground, where his Horns are also ready to do what in them lies to toss the Dog; and this is the true sport.

But if more Dogs than one come at once, or if they are cowardly and come under his legs, he will, if he can, stamp their Guts out.

I believe I have seen a Dog tossed by a Bull Thirty, if not Forty Foot high; and when they are tossed either higher or lower, the Men about strive to catch them on their Shoulders, lest the fall might mischief the Dogs.

They commonly lay Sand about, that if they fall upon the Ground, it may be the easier.

Notwithstanding this care, a great many Dogs are killed, more have their Limbs broke; and some hold so fast, that by the Bull's swinging them, their Teeth are often broke out. 
To perfect the History of Bull-baiting I must tell you, that the famed Dogs have Crosses or Roses of various Coloured Ribbon stuck with Pitch on their Foreheads; and such like the Ladies are very ready to bestow on Dogs or Bull that do valiantly; and when 'tis stuck on the Bulls Forehead, that Dog is holla'd that fetches it off; tho' the true Courage and Art is to hold the Bull by the Nose till he roars; which a courageous Bull scorns to do.

Often the Men are tossed as well as the Dogs; and Men, Bull, and Dogs seem exceeding pleased, and as earnest at the sport as if it were for their Lives or Livelihoods.

Many great Wagers are laid on both sides; and great Journeys will Men and Dogs go for such a Diversion. I knew a Gentleman that bought a Bull in Hertfordshire on purpose to go a Progress with him, at a great charge, into most of the great Towns in the West of England.

This is a sport the English much delight in; and not only the baser sort but the greatest Lords and Ladies.

John Houghton. 
(From The Chace)

FIRST let the Kennel be the huntsman's care,

Upon some little eminence erect, And fronting to the ruddy dawn; its courts On either hand wide op'ning to receive The sun's all-cheering beams, when mild he shines, And gilds the mountain tops. For much the pack (Rous'd from their dark alcoves) delight to stretch, And bask, in his invigorating ray:

Warn'd by the streaming light, and merry lark, Forth rush the jolly clan; with tuneful throats They carol loud, and in grand chorus join'd Salute the new-born day.

Let no Corinthian pillars prop the dome, A vain expence, on charitable deeds Better dispos'd, to clothe the tatter'd wretch, Who shrinks beneath the blast, to feed the poor Pinch'd with afflictive want: For use, not state, Gracefully plain, let each apartment rise. O'er all let cleanliness preside, no scraps Bestrew the pavement, and no half-pick'd bones, To kindle fierce debate, or to disgust That nicer sense, on which the sportsman's hope And all his future triumphs must depend. Soon as the growling pack with eager joy Have lapp'd their smoking viands, morn or eve, 
From the full cistern lead the ductile streams, To wash thy court well-pav'd, nor spare thy pains, For much to health will cleanliness avail. Seek'st thou for hounds to climb the rocky stecp, And brush th' entangled covert, whose nice scent

O'er greasy fallows and frequented roads Can pick the dubious way? Banish far off Each noisome stench, let no offensive smell Invade thy wide inclosure, but admit The nitrous air and purifying breeze.

Water and shade no less demand thy care: In a large square th' adjacent field inclose, There plant in equal ranks the spreading elm, Or fragrant lime; most happy thy design, If at the bottom of thy spacious court, A large canal fed by the crystal brook From its transparent bosom shall reflect Downward thy structure and inverted grove. Here when the sun's too potent gleams annoy The crowded kennel, and the drooping pack Restless and faint loll their unmoisten'd tongues, And drop their feeble tails; to cooler shades Lead forth the panting tribc; soon shalt thou find The cordial breeze their fainting hearts revive: Tumultuous soon they plunge into the stream, There lave their reeking sides, with greedy joy Gulp down the flying wave, this way and that From shore to shore they swim, while clamour loud 46 
And wild uproar torments the troubled flood: Then on the sunny bank they roll and stretch Their dripping limbs, or else in wanton rings Coursing around, pursuing and pursued, The merry multitude disporting play.

See there with count'nance blith, And with a courtly grin, the fawning hound Salutes thee cow'ring, his wide op'ning nose Upward he curls, and his large sloe-black eyes Melt in soft blandishments and humble joy; His glossy skin, or yellow-pied, or blue, In lights or shades by Nature's pencil drawn, Reflects the various tints; his ears and legs Fleckt here and there, in gay enamel'd pride Rival the speckled pard; his rush-grown tail O'er his broad back bends in an ample arch; On shoulders clean, upright and firm he stands; His round cat foot, strait hams, and wide-spread thighs,

And his low-dropping chest, confess his speed, His strength, his wind, or on the steepy hill, Or far-extended plain; in ev'ry part So well proportion'd, that the nicer skill Of Phidias himself can't blame thy choice. Of such compose thy pack.

Huntsman, lead on! behind the clust'ring pack Submiss attend, hear with respect thy whip 
Loud-clanging, and thy harsher voice obey ; Spare not the straggling cur, that wildly roves; But let thy brisk assistant on his back Imprint thy just resentments; let each lash Bite to the quick, till howling he return And whining creep amid the trembling crowd.

Here on this verdant spot, where Nature kind With double blessings crowns the farmer's hopes; Where flow'rs autumnal spring, and the rank mead Affords the wand'ring hares a rich repast, Throw off thy ready pack. See, where they spread And range around, and dash the glitt'ring dew. If some stanch hound, with his authentic voice, Avow the recent trail, the justling tribe Attend his call, then with one mutual cry The welcome news confirm, and echoing hills Repeat the pleasing tale. See how they thread The brakes, and up yon furrow drive along! But quick they recoil, and wiscly check Their eager haste; then o'er the fallow'd ground How leisurely they work, and many a pause Th' harmonious concert breaks.

Here, huntsman, bring (But without hurry) all thy jolly hounds, And calnuly lay them in. How low they stoop, And seem to plough the ground! then all at once With greedy nostrils snuff the fuming steam 
That glads their fluttering hearts. As winds let loose

From the dark caverns of the blust'ring god, They burst away, and sweep the dewy lawn.

Hope gives them wings while she's spur'd on by fear. The welkin rings, men, dogs, hills, rocks, and woods

In the full concert join. Now, my brave youths, Stript for the chace, give all your souls to joy!

Once more, ye jovial train, your courage try, And each clean courser's speed. We scour along, In pleasing hurry and confusion tost ; Oblivion to be wish'd. The patient pack Hang on the scent unweary'd, up they climb, And ardent we pursue; our lab'ring steeds We press, we gore; till once the summit gain'd, Painfully panting, there we breathe a while; Then like a foaming torrent, pouring down Precipitant, we smoke along the vale. Happy the man who with unrival'd speed Can pass his fellows, and with pleasure view The struggling pack; how in the rapid course Alternate they preside, and justling push To guide the dubious scent; how giddy youth Oft babbling errs, by wiser age reprov'd ; How, niggard of his strength, the wise old hound Hangs in the rear, till some important point Rouse all his diligence, or till the chace E 
Sinking he finds; then to the head he springs, With thirst of glory fir'd, and wins the prize. Huntsman, take heed; they stop in full career. Yon crowding flocks, that at a distance graze, Have haply foil'd the turf. See! that old hound, How busily he works, but dares not trust His doubtful sense; draw yet a wider ring. Hark! now again the chorus fills. As bells Sally'd a while at once their peal renew, And high in air the tuneful thunder rolls. See, how they toss, with animated rage Recov'ring all they lost !- - That eager haste Some doubling wile foreshews. - Ah ! yet once more They're check'd - hold back with speed-on either hand

They flourish round-ev'n yet persist-'tis right, Away they spring; the rustling stubbles bend Beneath the driving storm. Now the poor chace Begins to flag, to her last shifts reduc'd. From brake to brake she flies, and visits all Her well-known haunts, where once she rang'd secure,

With love and plenty blest. See! there she goes, She reels along, and by her gait betrays Her inward weakness. See, how black she looks ! The sweat that clogs th' obstructed pores, scarce leaves

A languid scent. And now in open view, See, see, she flies! each eager hound exerts 
His utmost speed, and stretches ev'ry nerve. How quick she turns! their gaping jaws eludes, And yet a moment lives; till round inclosed By all the greedy pack, with infant screams She yields her breath, and there reluctant dies.

Ere yet the morning peep Or stars retire from the first blush of day, With thy far-echoing voice alarm thy pack, And rouse thy bold compeers. Then to the copse, Thick with entangling grass, or prickly furze, With silence lean thy many coloured hounds, In all their beauty's pride. See! how they range Dispers'd, how busily this way and that They cross, examining with curious nose Each likely haunt. Hark! on the drag I hear Their doubtful notes, preluding to a cry More nobly full, and swell'd with ev'ry mouth. As straggling armies at the trumpet's voice, Press to their standard; hither all repair, And hurry thro' the woods; with hasty step Rustling, and full of hope ; now driv'n on heaps They push, they strive; while from his kennel sneaks The conscious villain. Sce! he skulks along, Sleek at the shepherd's cost, and plump with meals Purloin'd. So thrive the wicked here below. 'Tho' high his brush he bears, tho' tipt with white It gaily shine; j'et ere the sun declin'd Recall the shades of night, the pamper'd rogue 
Shall rue his fate revers'd ; and at his heels Behold the just avenger, swift to seize His forfeit head, and thirsting for his blood.

Heav'ns! what melodious strains! how beat our hearts

Big with tumultuous joy! The loaded gales Breathe harmony; and as the tempest drives From wood to wood, thro' ev'ry dark recess The forest thunders, and the mountains shake. The chorus swells; less various, and less sweet The trilling notes, when in those very groves The feather'd choristers salute the spring, And ev'ry bush in concert joins ; or when The master's hand in modulated air Bids the loud organ breathe, and all the pow'rs Of music in one instrument combine, An universal minstrelsy. And now In vain each earth he tries, the doors are barr'd Impregnable, nor is the covert safe ; He pants for purer air. Hark! what loud shouts Re-echo thro' the groves! He breaks away, Shrill horns proclaim his flight. Each straggling hound

Strains o'er the lawn to reach the distant pack.

What lengths we pass! where will the wand'ring chace

Lead us bewilder'd? Smooth as the swallows skim 
The new-shorn mead, and far more swift we fly. See my brave pack! how to the head they press, Justling in close array; then more diffuse Obliquely wheel, while from their op'ning mouths The vollied thunder breaks. So when the cranes Their annual voyage steer, with wanton wing Their Figure of they change, and their loud clang From cloud to cloud rebounds. How far behind The hunter-crew, wide straggling o'er the plain !

Here, huntsman, from this height Observe yon birds of prey; if I can judge, 'Tis there the villain lurks; they hover round And claim him as their own. Was I not right? See ! there he creeps along; his brush he drags, And sweeps the mire impure; from his wide jaws His tongue unmoisten'd hangs; symptoms too sure Of sudden death. Ha! yet he flies, nor yields To black despair. But one loose more, and all His wiles are vain. Hark ! thro' yon village now The rattling clamour rings. The barns, the cots, And leafless elms return the joyous sounds. 'Thro' ev'ry homestall, and thro' ev'ry yard, His midnight walks, panting, forlorn, he flies; Thro' ev'ry hole he sneaks, thro' ev'ry jakes l'lunging he wades besmear'd, and fondly hopes In a superior stench he lose his own: l'ut faithful to the track, th' unerring hounds With peals of echoing vengeance close pursue. 
And now distress'd, no shelt'ring covert near, Into the hen-roost creeps, whose walls with gore Distain'd attest his guilt. There, villain, there Expect thy fate deserv'd. And soon from thence The pack inquisitive, with clamor loud, Drag out their trembling prize; and on his blood With greedy transport feast. In bolder notes Each sounding horn proclaims the felon dead: And all th' assembled village shouts for joy.

\section{Rapine and spoil}

Haunt ev'n the lowest deeps; seas have their sharks,

Rivers and ponds inclos'd the rav'nous pike;

He in his turn becomes a prey; on him

Th' amphibious otter feasts. Just is his fate

Deserv'd ; but tyrants know no bounds; nor spears

That bristle on his back defend the perch

From his wide greedy jaws; nor burnish'd mail

The yellow carp; nor all his arts can save Th' insinuating eel, that hides his head Beneath the slimy mud; not yet escapes The crimson-spotted trout, the river's pride, And beauty of the stream. Without remorse, This midnight pillager ranging around, Insatiate swallows all. The owner mourns Th' unpeopled rivulet, and gladly hears The huntsman's early call, and sees with joy The jovial crew, that march upon its banks 
In gay parade, with bearded lances arm'd.

$$
\text { Huntsman, bring }
$$

Thy eager pack, and trail him to his couch. Hark! the loud peal begins, the clam'rous joy, The gallant chiding, loads the trembling air.

\section{How greedily}

They snuff the fishy steam, that to each blade Rank-scenting clings! See! how the morning dews They sweep, that from their feet besprinkling drop Dispers'd, and leave a track oblique behind. Now on firm land they range; then in the flood They plunge tumultuous; or thro' reedy pools Rustling they work their way: no holt escapes Their curious search. With quick sensation now The fuming vapour stings ; flutter their hearts, And joy redoubled bursts from ev'ry mouth In louder symphonies. Yon hollow trunk, That with its hoary head incurv'd salutes The passing wave; must be the tyrant's fort, And dread abode. How these impatient climb, While others at the root incessant bay:

They put him down. See, there he dives along! Th' ascending bubbles mark his gloomy way. Quick fix the nets, and cut off his retreat Into the shelt'ring deeps. Ah, there he vents ! The pack lunge headlong, and protended spears Menace destruction: while the troubled surge 
Indignant foams, and all the scaly kind Affrighted hide their heads. Wild tumult reigns, And loud uproar. Ah, there once more he vents! See, that bold hound has seiz'd him; down theysink, Together lost: but soon shall he repent His rash assault. See there escap'd, he flies Half-drown'd, and clambers up the slipp'ry bank With ooze and blood distain'd. Of all the brutes, Whether by Nature form'd, or by long use, This artful diver best can bear the want Of vital air. Unequal is the fight Beneath the whelming element. Yet there He lives not long; but respiration needs At proper intervals. Again he vents; Again the crowd attack. That spear has pierc'd His neck; the crimson waves confess the wound. Fix'd is the bearded lance, unwelcome guest Where'er he flies; with him it sinks beneath, With him it mounts; sure guide to ev'ry foe. Inly he groans; nor can his tender wound Bear the cold stream. Lo! to yon sedgy bank He creeps disconsolate; his num'rous foes Surround him, hounds and men. Pierc'd thro' and thro',

On pointed spears they lift him high in air; Wriggling he hangs, and grins, and bites in vain: Bid the loud horns, in gaily-warbling strains, Proclaim the felon's fate; he dies, he dies.

William Somerville. $5^{6}$ 
Upon a Dog called Fuddle, Turnspit at the Popinjay, in Norwich

(From Norfolk Drollery)

FUDDLE, why so? Some fuddle-cap sure
came

Into the room, and gave him his own name;

How should he catch a fox? He'll turn his back Upon tobacco, beer, French wine, or sack.

A bone his jewel is; and he does scom, With Esop's cock, to wish a barley-corn. There's not a soberer dog, I know, in Norwich, What . . would ye have him drunk with porridge? This I confess, he goes around, around, A hundred times, and never touches ground; And in the middle circle of the air He draws a circle like a conjuror. With eagerness he still does forward tend, Like Sisyphus, whose journey has no end. $\mathrm{He}$ is the soul (if wood has such a thing) And living posy of a wooden ring. He is advanced above his fellows, yet He does not for it the least envy get. He does above the Isle of Dogs commence, And wheels the inferior spit by influence. This, though, befalls his more laborious lot, $\mathrm{He}$ is the Dog-star, and his days are hot. Yet with this comfort there's no fear of burning, 
'Cause all the while the industrious wretch is turning.

Then no more Fuddle say; give him no spurns, But wreak your spleen on one that never turns, And call him, if a proper name he lack, A four-foot hustler, or a living Jack.

On the Collar of 'Tiger, Mrs. Dingley's Lap-Dog

PRAY steal me not; I'm Mrs. Dingley's, 1 Whose heart in this four-footed thing lies. Jonathan Swift.

On Rover, a Lady's Spaniel: Instructions to a Painter
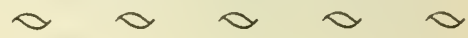

H APPIEST of the spaniel race,

H Painter, with thy colours grace:

Draw his forehead large and high,

Draw his blue and humid eye;

Draw his neck so smooth and round,

Little neck with ribbons bound:

And the muscly swelling breast,

Where the Loves and Graces rest ;

And the spreading even back, Soft, and sleek, and glossy black;

And the tail that gently twines, 
Like the tendrils of the vines;

And the silky twisted hair,

Shadowing thick the velvet ear ;

Velvet ears, which, hanging low,

O'er the veiny temples flow.

With a proper light and shade,

Let the winding hoop be laid;

And within that arching bower,

(Secret circle, mystic power,)

In a downy slumber place

Happiest of the spaniel race ;

While the soft respiring dame,

Glowing with the softest flame,

On the ravish'd favourite pours

Balmy dews, ambrosial showers

With thy utmost skill express

Nature in her richest dress,

Limpid rivers smoothly flowing,

Orchards by those rivers blowing ;

Curling woodbine, myrtle shade, And the gay enamell'd mead;

Where the linnets sit and sing,

Little sportlings of the spring;

Where the breathing ficld and grove

Soothe the heart, and kindle love.

Here for me, and for the Musc,

Colours of resemblance choose,

Make of lineaments divine.

Daply female spanicls shine, 
Pretty fondlings of the fair, Gentle damsels' gentle care ;

But to one alone impart

All the flattery of thy art.

Crowd each feature, crowd each grace,

Which complete the desperate face;

Let the spotted wanton dame

Feel a new resistless flame!

Let the happiest of his race Win the fair to his embrace.

But in shade the rest conceal,

Nor to sight their joys reveal,

Lest the pencil and the Muse

Loose desires and thoughts infuse.

Jonathan Swift.

An Elegy on a Lap-1)og

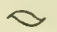

$\propto$

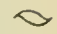

SHOCK'S fate I mourn; poor Shock is now no more,

Ye Muses mourn, ye chamber-maids deplore.

Unhappy Shock! yet more unhappy Fair, Doom'd to survive thy joy and only care ! Thy wretched fingers now no more shall deck, And tie the fav'rite ribband round his neck; No more thy hand shall smooth his glossy hair, And comb the wavings of his pendent ear. Yet cease thy flowing grief, forsaken maid; 60 
All mortal pleasures in a moment fade :

Our surest hope is in an hour destroy'd, And love, best gift of heav'n, not long enjoy'd.

Methinks I see her, frantic with despair,

Her streaming eyes, wrung hands, and flowing hair ;

Her Mechlen pinners rent the floor bestrow, And her torn fan gives real signs of woe.

Hence Superstition, that tormenting guest, That haunts with fancied fears the coward breast ; No dread events upon this fate attend, Stream eyes no more, no more thy tresses rend. Tho' certain omens oft forewarn a state, And dying lions show the monarch's fate; Why should such fears bid Celia's sorrow rise, For when a Lap-dog falls no lover dies.

Cease, Celia, cease ; restrain thy flowing tears, Some warmer passion will dispel thy cares. In man you'll find a more substantial bliss, More grateful toying and a sweeter kiss.

He's dead. Oh lay him gently in the ground: And may his tomb be by this verse renowned: Here Shock, the pride of all his kind, is laid;

Who fawn'd like man, but ne'er like man betray'dl.

John Gay. 
7 HOSE who in quarrels interpose

A Mastiff, of true English blood, Loved fighting better than his food. When dogs were snarling for a bone, He long'd to make the war his own, And often found (when two contend) To interpose obtain'd his end ; He gloried in his limping pace; 'The scars of honour seam'd his face; In ev'ry limb a gash appears, And frequent fights retrenched his ears.

As, on a time, he heard from far Two dogs engaged in noisy war, Away he scours and lays about him, Resolved no fray should be without him.

Forth from his yard a tanner flies, And to the bold intruder cries:

A cudgel shall correct your manners Whence sprung this cursed hate to tanners? While on my dog you vent your spite, Sirrah! 'tis me you dare not bite.

'To see the battle thus perplex'd With equal rage a butcher vex'd, Hoarse-screaming from the circled crowd, To the cursed Mastiff cries aloud :

Both Hockley-Hole and Mary-bone 62 
The combats of my dog have known.

He ne'er, like bullies coward-hearted, Attacks in public to be parted.

Think not, rash fool, to share his fame:

Be his the honour or the shame.

Thus said, they swore, and raved like thunder; They dragg'd their fasten'd dogs asunder ;

While clubs and kicks from ev'ry side

Rebounded from the Mastiff's hide.

All reeking now with sweat and blood,

A while the parted warriors stood,

Then poured upon the meddling foe,

Who, worried, howl'd and sprawl'd below.

He rose, and limping from the fray,

By both sides mangled, sneak'd away.

John Gay.

The Cur, the Horse, and the Shepherd's Dog $\curvearrowright$

THE lad of all-sufficient merit

With modesty ne'er damps his spirit ;

l'resuming on his own deserts,

On all alike his tongue exerts;

His noisy jokes at random throws, And pertly spatters friends and foes;

In wit and war the bully race

Contribute to their own disgrace.

Too late the forward youth shall find 
That jokes are sometimes paid in kind; Or if they canker in the breast, He makes a foe who makes a jest.

A village cur, of snappish race, The pertest P'uppy of the place, Imagined that his treble throat Was blest with music's sweetest note;

In the mid road he basking lay, The yelping nuisance of the way;

For not a creature pass'd along, But had a sample of his song.

Soon as the trotting steed he hears, He starts, he cocks his dapper ears; Away he scours, assaults his hoof; Now near him snarls, now barks aloof; With shrill impertinence attends, Nor leaves him till the village ends. It chanced, upon his evil day, A Pad came pacing down the way; The Cur, with never-ceasing tongue, Upon the passing trav'ller sprung. The Horse, from scorn provoked to ire, Flung backward: rolling in the mire, The Puppy howl'd, and bleeding lay; The Pad in peace pursued his way.

A Shepherd's Dog, who saw the deed, Detesting the vexatious breed, Bespoke him thus: When coxcombs prate, They kindle wrath, contempt, or hate; 
Thy teasing tongue had judgment tied, Thou had'st not, like a puppy, died.

John Gay.

The Cook-Maid, the Turnspit, and the Ox $\curvearrowright$

To a Poor Man

CONSIDER man in ev'ry sphere, Then tell me is your lot severe?

'Tis murmur, discontent, distrust, That makes you wretched. God is just.

I grant, that hunger must be fed, That toil, too, earns thy daily bread. What then? Thy wants are seen and known, But ev'ry mortal feels his own.

We're born a restless needy crew :

Shew me the happier man than you.

Adlam, though blest above his kind, For want of social woman pined. Eve's wants the subtle serpent saw, Her fickle taste transgress'd the law : Thus fell our sire; and their clisgrace The curse entail'd on human race.

When Philip's son, by glory led, Had o'er the globe his empire spread; When altars to his name were dress'd, F 
That he was man, his tears confess'd.

The hopes of avarice are check'd:

The proud man always wants respect. What various wants on power attend?

Ambition never gains its end.

Who hath not heard the rich complain

Of surfeits and corporeal pain?

He barr'd from ev'ry use of wealth,

Envies the ploughman's strength and health.

Another in a beauteous wife

Finds all the miseries of life:

Domestic jars and jealous fear

Embitter all his days with care.

This wants an heir, the line is lost:

Why was that vain entail engross'd?

Can'st thou discern another's mind? What is't you envy? Envy's blind. Tell Envy, when she would annoy, That thousands want what you enjoy.

The dinner must be dish'd at one, Where's this vexatious Turnspit gone?

Unless the skulking Cur is caught, The sirloin's spoil'd, and I'm in fault. Thus said : (for sure you'll think it fit That I the Cook-maid's oaths omit)

With all the fury of a cook, Her cooler kitchen Nan forsook.

The broomstick o'er her head she waves; She sweats, she stamps, she puffs, she raves. 
The sneaking Cur before her flies:

She whistles, calls; fair speech she tries.

These nought avail. Her choler burns;

The fist and cudgel threat by turns ;

With hasty stride she presses near; He slinks aloof, and howls with fear.

Was ever Cur so cursed! (he cried)

What star did at my birth preside?

Am I for life by compact bound

To tread the wheel's eternal round?

Inglorious task : Of all our race

No slave is half so mean and base.

Had fate a kinder lot assign'd,

And formed me of the lap-dog kind,

I, then, in higher life employ'd,

Had indolence and ease enjoy'd;

And, like a gentleman, caress'd,

Had been the lady's fav'rite guest.

Or were I sprung from spaniel line,

Was his sagacious nostril mine,

By me, their never-erring guide,

From wood and plain their feasts supplied,

Knights, squires, attendant on my pace,

Had shared the pleasures of the chase.

Endued with native strength and fire,

Why call'd I not the lion sire?

A lion: such mean views I scorn;

Why was I not of woman born?

Who dares with reason's power contend? 
On man we brutal slaves depend:

To him all creatures tribute pay,

And luxury employs his day.

An ox by chance o'erheard his moan, And thus rebuked the lazy drone:

Dare you at partial fate repine?

How kind's your lot compared with mine!

Decreed to toil, the barb'rous knife

Hath severed me from social life;

Urged by the stimulating goad,

I drag the cumbrous waggon's load:

'Tis mine to tame the stubborn plain, Break the stiff soil, and house the grain:

Yet I without a murmur bear

The various labours of the year.

But then consider, that one day

(Perhaps the hour's not far away),

You, by the duties of your post,

Shall turn the spit when I'm the roast :

And for reward shall share the feast,

I mean, shall pick my bones at least.

'Till now, the astonish'd Cur replies,

I look'd on all with envious eyes.

How false we judge by what appears!

All creatures feel their sev'ral cares.

If thus yon mighty beast complains,

Perhaps man knows superior pains.

Let envy them no more torment :

Think on the $\mathrm{Ox}$, and learn content. 
Thus said : close following at her heel, With cheerful heart he mounts the wheel.

John Gay.

\section{A Fragment: Of a Poem on Hunting $\propto \propto$}

Dona cano divîm laetas venantibus artes, Auspicio, Diana, tuo-

Gratius.

THY care be first the various gifts to trace, The minds and genius of the latrant race.

In powers distinct the different clans excel, In sight, or swiftness, or sagacious smell ; By wiles ungenerous some surprise the prey, And some by courage win the doubtful day. Seest thou the gazehound: how with glance severe,

From the close herd he marks the destin'd deer ! How every nerve the greyliound's stretch displays, The hare preventing in her airy maze;

The luckless prey how treacherous tumblers gain, And dauntless wolf-dogs shake the lion's mane: O'er all, the bloodhound boasts superior skill, 'To scent, to view, to turn, and boldly kill : His fellows' vain alarms rejects with scorn, True to the master's voice, and learned horn. His nostrils oft, if ancient Fame sing true, Trace the sly felon through the tainted dew; 
Once snuff d, he follows with unalter'd aim, Nor odours lure him from the chosen game; Deep-mouth'd he thunders, and inflam'd he views, Springs on relentless, and to death pursues.

Some hounds of manners vile, (nor less we find Of fops in hounds, than in the reasoning kind,) Puff'd with conceit run gladding o'er the plain, And from the scent divert the wiser train ; For the foe's footsteps fondly snuff their own, And mar the music with their senseless tone; Start at the starting prey, or rustling wind, And, hot at first, inglorious lag behind.

A sauntering tribe! may such my foes disgrace ! Give me, ye gods, to breed the nobler race. Nor grieve thou to attend, while truths unknown I sing, and make Athenian arts our own.

Dost thou in hounds aspire to deathless fame? Learn well their lineage and their ancient stem. Each tribe with joy old rustic heralds trace, And sing the chosen worthies of their race; How his sire's features in the son were spy'd, When Die was made the vigorous Ringwood's bride.

Less sure thick lips the fate of Austria doom, Or eagle noses rul'd almighty Rome.

Good shape to various kinds old bards confine, Some praise the Greek, and some the Roman line ; And dogs to beauty make as differing claims, As Albion's nymphs, and India's jetty dames. 
Immense to name their lands, to mark their bounds, And paint the thousand families of hounds :

First count the sands, the drops where oceans flow, Or Gauls by Marlborough sent to shades below, The task be mine, to back Britannia's swains, My much-lov'd country, and my native plains. Such be the dog, I charge, thou mean'st to train,

His back is crooked, and his belly plain, Of fillet stretch'd, and huge of haunch behind, A tapering tail, that nimbly cuts the wind; Truss-thigh'd, straight-ham'd, and fox-like form'd his paw,

Large-legg'd, dry-sol'd, and of protended claw. His flat, wide nostrils snuff the savoury steam, And from his eyes he shoots pernicious gleam; Middling his head, and prone to earth his view, With ears and chest that dash the morning dew : He best to stem the flock, to leap the bound, And charm the Dryads with his voice profound; To pay large tribute to his weary lord, And crown the sylvan hero's plenteous board.

The matron bitch whose womb shall best produce

The hopes and fortune of th' illustrious house, Deriv'd from noble, but from foreign seed, For various nature loaths incestuous breed, Is like the sire throughout. 
And now thy female bears in ample womb The bane of hares, and triumphs yet to come.

No sport, l wean, nor blast of sprightly horn, Should tempt me then to hurt the whelps unborn. Unlock'd, in covers let her freely run, To range thy courts, and bark before the sun; Near thy full table, let the favourite stand, Strok'd by thy son's, or blooming daughter's hand. Caress, indulge, by arts the matron bride, $\mathrm{T}$ 'improve her breed and teem a vigorous tribe.

\section{Thomas Tickell.}

Argus $\propto$
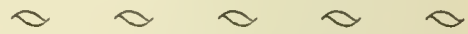

$W^{\text {HEN wise Ulysses, from his native coast }}$ Long kept by wars, and long by tempests tossed,

Arrived at last, poor, old, disguised, atone, To all his friends and ev'n his Queen unknown;

Changed as he was, with age, and toils, and cares,

Furrowed his reverend face, and white his hairs, In his own palace forced to ask his bread, Scorned by those slaves his former bounty fed, Forgot of all his own domestic crew ;

The faithful dog alone his rightful master knew ! Unfed, unhoused, neglected, on the clay, 
Like an old servant, now cashiered, he lay;

Touched with resentment of ungrateful man, And longing to behold his ancient lord again. Him when he saw--he rose and crawled to meet, ('Twas all he could) and fawned and kissed his feet,

Seized with dumb joy-then falling by his side, Owned his returning lord, looked up, and died : Alexander Pope.

Epigram engraved on the Collar of a Dog which I gave to His Royal Highness

I AMl his Highness' dog at Kew ;

Pray tell me, sir, whose dog are you?

Alexander Pope.

The Indian and $\mathrm{H}$ is $\mathrm{I} \log$
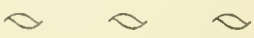

(From the Essay on iYan)

I $\mathrm{O}$, the poor Indian! whose untutored mind Sees God in clouds, or hears Him in the wind;

His soul, proud Science never taught to stray

Far as the solar walk or milky way ;

Yet simple Nature to his hope has given,

liehind the cloud-topped hill, an humbler heaven; Some safer world in depth of woods embraced, 
Some happier island in the watery waste, Where slaves once more their native land behold, No fiends toment, no Christians thirst for gold. To be, contents his natural clesire, He asks no angel's wings, no seraph's fire:

But thinks, admitted to that equal sky, His faitliful dog shall bear him company.

Alexander Pope.

Part of a letter to Mr. Henry Cromwell

NOWV I talk of my dog that I may not treat of a worse subject, which my spleen prompts me to. I will give you some account of him, a thing not wholly unprecedented, since Montaigne (to whom I am but a dog in comparison) has done the same thing of his cat. Dic mihi quid melius desidiosus agam? You are to know, then, that it is likeness begets affection, so my favourite $\operatorname{dog}$ is a little one, a lean one, and none of the finest shaped. He is not much a spaniel in his fawning, but has, (what might be worth any man's while to imitate him in) a dumb, surly sort of kindness, that rather shows itself when he thinks me ill-used by others, than when we walk quietly or peaccably by ourselves. If it be the chief point of friendship to comply with a friend's motions and inclinations, lie possesses this in an 
eminent degree: he lies down when I sit, and walks when I walk, which is more than many good friends can pretend to. Witness our walk a year ago in St. James's Park. Histories are more full of examples of the fidelity of dogs than of friends, but I will not insist upon many of them, because it is possible some may be almost as fabulous as those of Pylades and Orestes, etc. I will only say, for the honour of dogs, that the two most ancient and estimable books, sacred and profane, extant (viz. the Scripture and Homer), have shown a particular regard to these animals. That of Tobit is the more remarkable, because there seemed no manner of reason to take notice of the dog, besides the great humanity of the author.

Plutarch, relating how the Athenians were obliged to abandon Athens in the time of Themistocles, steps back again out of the way of his history, purely to describe the lamentable cries and howlings of the poor dogs they left behind. He makes mention of one that followed his master across the sea to Salamis, where he died, and was honoured with a tomb by the Athenians, who gave the name of the Dog's Grave to that part of the island where he was buried.

This respect to a dog in the most polite people in the world is very observable. A modern instance of gratitude to a dog (though we have few such) is, that the chief order of Denmark 
(now injuriously called the order of the elephant) was instituted in memory of the fidelity of a dog, named Wild-brat, to one of their kings who had been deserted by his subjects; he gave his order this motto, or to this effect (which still remains), Hild-brat was faithful. Sir William Trumbull has told me a story (said to be in Sir Philip Warwick's Mcmoirs), which he heard from one that was present: King Charles I. being with some of his court during his troubles, a discourse arose what sort of dogs deserved pre-cminence, and it being on all hands agreed to belong either to the spaniel or greyhound, the King gave his opinion on the part of the greyhound, because (said he) it has all the good-nature of the other, without fawning. A good piece of satire upon his courtiers, with which I will conclude my discourse of dogs. Call me a cynic, or what you please, in revenge for all this impertinence; I will be contented, provided you will but believe me when I say - a bold word for a Christian - that, of all dogs, you will find none more faithful thanYours, etc. Alexander Pope. 
(From M. Misson's Memoirs and Observations in his Trazels over England. Written originally in French, and translated by Mr. Ozell. London. I719.)

[ ERE follows the Manner of those Bull-baitings which are so much talk'd of: They tie a Rope to the Root of the Horns of the Ox or Bull, and fasten the other end of the Cord to an iron Ring fixed to a Stake driven into the Ground; so that, this Cord being about fifteen Feet long, the Bull is confined to a Space of about thirty Feet Diameter. Several butchers or other Gentlemen, that are desirous to exercise their Dogs, (These Dogs are but of a moderate Size), stand round about, each holding his own by the Ears; and when the Sport begins, they let loose one of the Dogs. The Dog runs at the Bull; the Bull, immovable, looks down upon the Dog with an Eye of Scorn, and only turns a Horn to him, to hinder him from coming near. The Dog is not daunted at this, he runs round him, and tries to get beneath his Belly, in order to seize him by the Muzzle, or the Dewlap: The Bull then puts himself into a Posture of Defence; he beats the Ground with his Fcet, which he joins together as closely as possible, and his chief $\mathrm{Aim}$ is not to gore the Doy with the Point of his Horn (which, when too sharp, is put into a Kind of wooden 
Sheath), but to slide one of them under the Dog's Belly, who creeps close to the Ground, to hinder it, and to throw him so high in the Air that he may break his Neck in the Fall. To avoid this Danger, the Dog's Friends are ready beneath him, some with their Backs, to give him a soft Reception: and others with long poles, which they offer him slantways, to the Intent that, sliding down them, it may break the Force of his Fall. Notwithstanding all this Care, a Toss generally makes him sing to a very scurvy Tune, and draw his Phiz into a pitiful Grimace. But unless he is totally stunmed with the Fall, he is sure to crawl again towards the Bull, come on't what will. Sometimes a second Frisk into the Air disables him for ever: but sometimes too he fastens upon his Enemy, and when once he has seized him with his Eye-teeth, he sticks to him like a Leech, and would sooner die than leave his Hold. Then the Bull bellows and bounds and kicks, all to shake off the Dog. In the End, either the Dog tears out the Piece he has laid Hold on, and falls, or else remains fixed to him with an Obstinacy that would never end, did they not pull him off. To call him away, would be in vain; to give him a hundred Blows, would be as much so ; you might cut him to Pieces, Joint by Joint, before he would let him loose. What is to be done then? While some hold the Bull, others thrust Staves into the 
Dog's Moutl, and open it by main Force. This is the only Way to part them.

Coursing the Hare
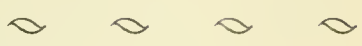

(From On a Country Life)
$\mathrm{A}^{\mathrm{T}}$ other times you may pursue the chase, And hunt the nimble hare from place to place.

See, when the dog is just upon the grip, Out at a side she'll make a handsome skip And ere he can divert his furious course, She, far before him, scours with all her force: She'll shift, and many times run the same ground; At last, outwearied by the stronger hound, She falls a sacrifice unto his hate, And with sad piteous screams laments her fate.

James Thomson.

On a Dog
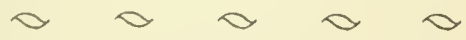

CALM though not mean, courageous without rage,

Serious not dull, and without thinking sage;

Pleas'd at the lot that Nature has assign'd, Snarl as I list, and freely bark my mind; 
As churchman whangle not with jarring spite, Nor stateman-like caressing whom I bite; View all the canine kind with equal eyes, I dread no mastiff, and no cur despise : True from the first, and faithful to the end, I baulk no mistress, and forsake no friend. My days and nights one equal tenour keep, Fast but to eat, and only wake to sleep : Thus stealing along life I live incog, A very plain and downright honest Dog.

William Hamilton.

\section{Buffon's Word for the Dog}
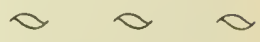
(From his Histoire Naturelle)

I T may be said that the dog is the only animal whose loyalty will stand trial; the only one who always knows his master and the friends of the family; the only one who, when a stranger comes, knows it ; the only one who knows his own name and recognises his master's voice; who does not trust himself; who, when he has lost his master, cries after him ; who, on a long road which he has only followed once, remembers and recovers the way; finally, the only one whose natural talents are plain and whose education always turns out well.

George Louis Leclerc Buffon. So 
Fighting Dogs $\curvearrowright$
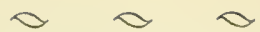

(From Tom Thumb the Great)

T $\mathrm{O}$, when two dogs are fighting in the streets,

With a third dog one of the two dogs meets, With angry teeth he bites him to the bone, And this dog smarts for what that dog has done.

Henry Fielding.

\section{An Appreciation $\diamond \propto \curvearrowright \propto$}

GENSE and fidelity are wonderful recommend$\checkmark$ ations; and when one meets with them, and can be confident that one is not imposed upon, I cannot think that the two additional legs are any drawback. At least I know that I have had friends who would never have vexed or betrayed me, if they had walked on all fours.

Horace Walpole.

Epitaph: On a favourite Lap-dog $\diamond \propto$

I NEVER bark'd when out of season;

I ne'er insulted weaker brother;

Nor wrong'd by force nor fraud another.

i; 
Though brutes are plac'd a rank below, Happy for man could he say so!

Thomas Blackcock.

The English Bull-dog, Dutch Mastiff, and Quail

\section{A SNUB-NOS'D dog, to fat inclin'd,}

A of the true hogan-mogan kind,

The favourite of an English dame,

Mynheer Van Trumpo was his name.

One morning as he chanc'd to range, Met honest Towzer on the 'Change;

And whom have we got here, I beg?

Quoth he, and lifted up his leg;

An English dog can't take an airing,

But foreign scoundrels must be staring.

I'd have your French dogs, and your Spanish,

And all your Dutch, and all your Danish,

By which our species is confounded,

Be hang'd, be poison'd, or be drowned;

No mercy on the race suspected,

Greyhounds from Italy excepted:

By them my dames ne'er prove big-bellied,

For they, poor toads, are Farrinellied.

Well, of all dogs it stands confessed,

Your English bull-dogs are the best;

I say it, and will set my hand to't ; 
Cambden records it, and I'll stand to't. 'Tis true we have too much urbanity, Somewhat o'ercharg'd with soft humanity; The best things must find food for railing, And every creature has its failing.

\section{Christopher Smart.}

An Elegy on the Death of a Mad Dog

COOD people all, of every sort,

$\checkmark$ Give ear unto my song;

And if you find it wondrous short,

It cannot hold you long.

In Islington there was a man, Of whom the world might say, That still a godly race he ran, Whene'er he went to pray.

A kind and gentle heart he had, To comfort friends and foes ; The naked every day he clad, When he put on his clothes.

And in that town a dog was found, As many dogs there be, Ioth mongrel, puppy; whelp, and hound, And curs of low degree. 
This $\log$ and man at first were friends ;

But when a pique began,

The dog, to gain his private ends,

Went mad, and bit the man.

Around from all the neighbouring streets

The wondering neighbours ran,

And swore the dog had lost its wits,

To bite so good a man.

The wound it seem'd both sore and sad

To every Christian eye ;

And while they swore the dog was mad, They swore the man would die.

But soon a wonder came to light, That show'd the rogues they lied;

The man recover'd of the bite, The dog it was that died.

Oliver Goldsmith.

The Winter Morning Walk

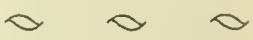
(From The Task)

FORTH goes the woodman, leaving unconcern'd The cheerful haunts of man to wield the axe And drive the wedge in yonder forest drear, From morn to eve his solitary task.

84 
Shaggy, and lean, and shrewd, with pointed ears And tail cropp'd short, half lurcher and half cur, His dog attends him. Close behind his heel Now creeps he slow; and now with many a frisk Wide scampering, snatches up the drifted snow With ivory teeth, or ploughs it with his snout; Then shakes his powder'd coat, and barks for joy.

Willian Cowper.

The Dog and the Water-Lily

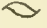

No Fable

THE noon was shady, and soft airs Swept Ouse's silent tide, When, 'scaped from literary cares, I wander'd on his side.

My spaniel, prettiest of his race, And high in pedigree, (Two nymphs adorn'd with every grace That spaniel found for me,)

Now wanton'd lost in flags and reeds, Now starting into sight, Pursued the swallow o'er the meads With scarce a slower flight. 
It was the time when Ouse display'd His lilies newly blown; Their beauties 1 intent survey'd, And one I wish'd my own.

With cane extended far I sought To steer it close to land; But still the prize, though nearly caught, Escaped my eager hand.

Beau mark'd my unsuccessful pains With fix'd considerate face, And puzzling set his puppy brains To comprehend the case.

But with a cherup clear and strong,

Dispersing all his dream, I thence withdrew, and follow'd long The windings of the stream.

My ramble ended, I return'd;

Beau, trotting far before, The floating wreath again discern'd, And plunging, left the shore.

I saw him with that lily cropp'd lmpatient swim to meet My quick approach, and soon he dropp'd The treasure at my feet. 
Charm'd with the sight, The world, I cried, Shall hear of this thy deed:

My dog shall mortify the pride Of man's superior breed :

But chief myself I will enjoin, Awake at duty's call, To shew a love as prompt as thine To Him who gives me all.

William Cowper.

Epitaph on Fop, a Dog belonging to Lady Throckmorton (August 1792)

$\prod_{\text {nome, }}^{\text {HOUGH once a puppy, and though Fop by }}$

Here moulders one whose bones some honour claim ;

No sycophant, although of spaniel race, And though no hound, a martyr to the chase.

Ye squirrels, rabbits, leverets, rejoice ! Your haunts no longer echo to his voice; This record of his fate exulting view, He died worn out with vain pursuit of you. "Yes," - the indignant shade of Fop replies"And worn with vain pursuit, man also dies." William Cowper. 
An Epitaph : On a Pointer belonging to Sir John Throckmorton

HERE lies one who never drew

H Blood himself, yet many slew ;

Gave the gun its aim, and figure Made in field, yet ne'er pull'd trigger.

Arm'd men have gladly made Him their guide, and him obey'd ; At his signified desire Would advance, present, and fire. Stout he was, and large of limb, Scores have fled at sight of him; And to all this fame he rose Only following his nose.

Neptune was he call'd; not he Who controls the boisterous sea, But of happier command, Neptune of the furrow'd land ; And, your wonder vain to shorten, Pointer to Sir John 'Throckmorton.

William Cowper. 
On a Spaniel, called Beau, killing a Young Bird

(Uuly 1793)

A SPANIEL, Beau, that fares like you, A Well fed, and at his ease, Should wiser be than to pursue Each trifle that he sees.

But you have kill'd a tiny bird, Which flew not till to-day, Against my orders, whom you heard Forbidding you the prey.

Nor did you kill that you might eat, And ease a doggish pain, For him, though chased with furious heat, You left where he was slain.

Nor was he of the thievisin sort, Or one whom blood allures, But innocent was all his sport Whom you have torn for yours.

My dog ! what remedy remains, Since, teach you all I can, I see you, after all my pains, So much resemble man?

William Cowper. 89 


\section{Beau's Reply}

$S^{1 R}$, when I flew to seize the bird

$S$ In spite of your command,

A louder voice than yours I heard,

And harder to withstand.

You cried-Forbear !-but in my breast

A mighticr cried - Proceed !-

'Twas Nature, Sir, whose strong behest

Impell'd me to the deed.

Yet much as Nature I respect,

I ventured once to break

(As you perhaps may recollect)

Her precept for your sake ;

And when your linnet on a day,

Passing his prison door,

Had flutter'd all his strength away

And panting press'd the floor.

Well knowing him a sacred thing,

Not destined to my tooth,

I only kiss'd his roffled wing,

And licked the feathers smooth.

Let my obedience then excuse My disobedience now, 
Nor some reproof yourself refuse

From your aggrieved bow-wow;

If killing birds be such a crime,

(Which I can hardly see,)

What think you, Sir, of killing time

With verse address'd to me?

William Cowper.

The Parson, the Squire, and the Spaniel $\propto$

A Tale

A GENTLEMAN possess'd a fav'rite spaniel, A That never treated maid nor man ill :

This dog, of whom we cannot too much say,

Got from his godfather the name of Tray.

After ten years of service just,

Tray, like the race of mortals, sought the dustThat is to say, the spaniel died:

A coffin then was order'd to be made, The dog was in the churchyard laid, And o'er his pale remains the master cry'd.

Lamenting much his trusty fur-clad friend, And willing to commemorate his end, He rais'd a small blue stone, just after burial, And weeping, wrote on it this sweet memorial: 


\section{TRAY'S EPITAPH}

Here rest the relics of a friend below

Blest with more sense than half the folks 1 know ;

Fond of his ease, and to no parties prone, He clamn'd no feet, but calmly gnaw'd his bone : Performed his functions well in ev'ry wayBlush, CHRISTIANS, if you can, and copy Tray.

The Curate of the Huntingtonian Band, Rare breed of gospel hawks that scour the land, And fierce on sins their quarry fall, Those Locusts, that would eat us all:

Men who with new-invented patent eyes, See Heav'n and all the angels in the skies; As plain as in the box of Showman Swiss, For little Master made, and curious Miss, We see with huge delight the king of France With all his Lords and Ladies dance:

This Curate heard th' affair with deep emotion, And thus exclaim'd, with infinite devotion: "O Lord! O Lord! O Lord! O Lord! Fine doings these, upon my word!

"This, truly, is a pretty thing!

What will become of this most shocking world? 
How richly such a rogue deserves to swing, And then to Satan's hottest flames be hurl'd :

"Oh! by this damned deed how I am hurried!

A dog in Christian ground be buried!

And have an epitaph forsooth so civil :

Egad! Old Maids will presently be found Clapping their dead ram cats in holy ground, And writing verses on each mousing devil."

Against such future casualty providing, The Priest set off, like Homer's Neptune striding

Vowing to put the culprit in the Court: He found him at the spaniel's humble grave; Not praying, neither singing of a stave; And thus began t' abuse him-not exhort-

"Son of the Dev'l, what hast thou done? Nought for the action can atone-

I should not wonder if the great Allwise Quick darted down His lightening all so red And dash'd to earth that wretch'd head,

Which dar'd so foul, so base an act devise.

"Bury a dog like Christian folk !-

None but the devil cou'd provoke

A man to perpetrate a deed so odd:

Our Inquisition soon the tale shall hear, And quickly your fine fleece shall sheer;

Why, such a villain can't believe in God!" 
"Softly! my rev'rend Sir," the squire repliect"Tray was as good a dog as ever diedNo education could his morals mend-

And what, perhaps, Sir, you may doubt,

Before his lamp of life went out, He order'd you a legacy, my friend."

"Did he-poor dog !" the soften'd priest rejoin'd, In accents pitiful and kind; "What! was it Tray? I'm sorry for poor Tray:

Why truly, dogs of such rare merit,

Such real nobleness of spirit, Should not like common dogs be put away.-

"Well! pray what was it that he gave, Poor fellow! ere he sought the grave?

I guess I may put confidence, Sir, in ye." "A piece of gold," the gentleman reply'd. "I'm much oblig'd to Tray," the Parson cry'd ; So left God's cause, and pocketed the guinca. Peter Pindar.

At the Bar
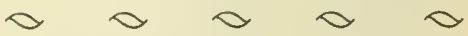

(From The Lower World)

STAND forth thou champion of a ruffian band, $D$ At mercy's bar uplift thy savage hand;

A train of wrong'd Accusers standing nigh, Truth, Justice, Nature, the dire cause shall try : 
First, answer to thy Dog, as first in place, Friend at thy board, companion of thy chase ; His no foul crime of "friend remembered not," Each kindness cherish'd, and each wrong forgot ; And though full oft he feels thy stripes unjust, He bears them all, and humbles to the dust; Unmurmuring bears them, and one slight caress, Tho' smitten to the bone, again can bless. Thy day of labour he is proud to share, And guards thy slumbers with a lover's care; Thy presence hails, thy absence fondly mourns, While bounding raptures mark thy wish'd returns ;

To rage, to anguish, e'en to Death, resigned,What nobler feelings boast thy nobler kind?

By nature fierce, at length subdued and mild, To each kind office of a duteous childWho, a dark Sire guides through the pressing throng,

See how yon Terrier gently leads along The feeble Beggar, to his custom'd stand, With piteous tale to woo the bounteous hand; In willing bonds, but master of the way, Ne'er leads that trusted friend, his charge, astray :

With slow, soft step, as conscious of his care, As if his own deep sorrows form'd the prayerShould yielding Charity the scrip supply, 
Tho' hunger press'd, untouched the boon would lie ; Eyes to the blind, he notes the passing thief, And guards the good Samaritan's relief; A faithful steward, amidst unbounded power, Patient he waits the home-returning hour; Then reconducts his master to his shed, And grateful banquets on the coarsest bread. And were that cheerless shed, by fortune plac'd In the chill cavern, or the naked waste, The sport of every storm, unroof'd and bare, This faithful slave would find a palace there; Would feel the labours of his love o'erpaid Near to his monarch master's pillow laid; Unchang'd by change of circumstance or place : O SACRED LESSON TO A PROUDER RACE!

But, reasoner, say, are these thy gifts of art, Or, native graces of the canine heart?

Say, does he owe this social change of statc To imitation of the fair and great?

Copied from thee, and do his virtues rise From man's example of the good and wise? If thou hast thus reclaimed from savage strife, And made him thus a link of social life, Ask thy own soul-that every harshness knowsHow oft his joys are follow'd by his woes; And if like thee, this slave could count his gains, Say, would his pleasures balance to his pains?

$$
9^{6}
$$


Behold those pains in varied forms display'd, Then reckon what the poor reclicim'd has paid For all thy boasted patronage, to prove The proud distinction of thy vaunted love.

Reckon those scars, which thy unkindness gave, A still-forgiving, still-insulted slave; Reckon that wanton gash, that mangled limb, From hateful vengeance this, and that from whim; Reckon that stunning stroke, which to the ground Brought thy true friend, to welter in his wound ; Count, too, the anguish of those sounding blows, And the deep stream, that blushes as it flows.

Wretch! could'st thou see him when thy useless breath

At last shall give thee to the grasp of death, When, haply, thy sole mourner, fix'd he stands, Watches thy couch, and licks thy barbarous hands; Those hands that long have tried their force to prove Thy heart was dead to pity, truth, and love. Ah : could'st thou view him seem to look a pray'r, Or heave the moan that seem'd to speak despair; Then follow sad thy body to the grave, There, each extremity of hunger brave; Nor quit the spot, till famine, fraud, or force, D rove him awhile to quit thy much-lov'd corse ; Soon to return - enamour'd of the spotThy savage nature, rage, and stripes forgot; 
Could'st thou see this, perchance one tear would start,

One brief compunction stir thy stony heart; Then might'st thou wish ingratitude forgiv'n, And dread that crime of hell to show offended Heav'n!

Samuel Jackson Pratt.

Inscription: On a Newfoundland Dog $\propto \propto$

E who wander thither
Pass not unheeded

The spot where poor Cæsar

Is deposited.

He was born of Newfoundland parents.

His vigilance, during many years, Was the safeguard of Encombe House;

His talents and manners were long

The amusement and delight Of those who resorted to it. Of his unshaken fidelity, Of his cordial attachment To his master and his family, A just conception cannot Be conveyed by language, Or formed, but by those Who intimately knew him. $9^{8}$ 
To his rank among created beings,

The power of reasoning is denied.

Cæsar manifested joy

For days before his master

Arrived at Encombe :

Cæsar manifested grief

For days before his master left it.

What name shall be given

To that faculty,

Which thus made expectation

A source of joy,

Which thus made expectation

A source of grief?

Lord Eldon.

The Dealer and Clerk

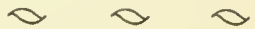

THERE watch'd a cur before the Miser's

A very cur, whom all men seem'd to hate;

Gaunt, savage, shaggy, with an eye that shone

Like a live coal, and he possess'd but one;

His bark was wild and eager, and became

That meagre body and that eye of flame;

His master prized him much, and Fang his name.

His master fed him largely; but not that,

Nor aught of kindness, made the snarler fat. 
Flesh he devour'd, but not a bit would stay; He bark'd, and snarl'd, and growl'd it all away. His ribs were seen extended like a rack, And coarse red hair hung roughly o'er his back. Lamed in one lcg, and bruised in wars of yore, Now his sore body made his temper sore. Such was the friend of him who could not find Nor make him one 'mong creatures of his kind. Brave deeds of Fang his master often told, The son of Fury, famed in deeds of old, From Snatch and Rabid sprung; and noted they In earlier times-each dog will have his day.

The notes of Fang were to his master known, And dear-they bore some likeness to his own; For both convey'd to his experienced ear, "I snarl and bite, because I hate and fcar." None pass'd ungreeted by the master's door,Fang railed at all, but chiefly at the poor; And when the nights were stormy, cold, and dark, The act of Fang was a perpetual bark; But though the master loved the growl of Fang, There were who vow'd the ugly cur to hang; Whose angry master, watchful for his friend, As strongly vow'd his servant to defend.

In one dark night, and such as Fang before Was ever known its tempests to outroar, To his protector's wonder now express'd 
No angry notes-his anger was at rest.

The wond'ring master sought the silent yard,

Left Phœbe sleeping and his door unbarr'd ;

Nor more return'd to that forsaken bed-

But lo! the morning came and he was dead.

Fang and his master side by side were laid

In grim repose-their debt of nature paid!

The master's hand upon the cur's cold chest

Was now reclined, and had before been press'd,

As if he search'd how deep and wide the wound

That laid such spirit in a sleep so sound;

And when he found it was the sleep of death,

A sympathising sorrow stopp'd his breath.

Close to his trusty servant he was found, As cold his body, and his sleep as sound.

George Crabbe.

The Twa Dogs
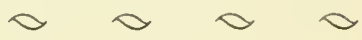

A Tale

'TIVAS in that place o' Scotland's isle, That bears the name o' auld King Coil,

Upon a bonnie day in June,

When wearing thro' the aftermoon,

Twa dogs, that were na thrang at hame,

Forgather'd ance upon a time.

The first I'll name, they ca'd him Ciesar, Was kecpit for his Honour's pleasure:

IO I 
His hair, his size, his mouth, his lugs, Shew'd he was nane o' Scotland's dogs; But whalpit some place far abroad, Whare sailors gang to fish for cod.

His locked, letter'd, braw brass collar Shew'd him the gentleman and scholar; But tho' he was o' high degree, The fient a pride-nae pride had he ; But wad hae spent an hour caressin', Ev'n w' a tinkler-gipsey's messin. At kirk or market, mill or smiddie, Nae tawted tyke, tho' e'er sae duddie, But he wad stan't, as glad to see him, An' stroan't on stanes and hillocks wi' him.

The tither was a ploughman's collie, A rhyming, ranting, raving billie, Wha for his friend an' comrade had him, $\mathrm{An}^{\prime}$ in his freaks had Luath ca'd him, After some dog in Highland sang, Was made lang syne-Lord knows how lang.

He was a gash an' faithfu' tyke, As ever lap a sheugh or dyke. His honest, sonsie, baws'nt face, Ay gat him friends in ilka place ; His breast was white, his touzie back Weel clad wi' coat o' glossy black; His gawcie tail, wi' upward curl, Hung owre his hurdies wi' a swirl. Nae doubt but they were fain o' ither, I02 
An' unco pack an' thick thegither;

IVi' social nose whyles snuff $d$ and snowkit;

Whyles mice and moudieworts they howkit;

Whyles scour'd awa in lang excursion,

An' worry'd ither in lang diversion;

Until wi' daffin' weary grown,

Upon a knowe they sat them down, An' there began a lang digression

About the lords o' the creation.

Robert Burns.

On the Death of a Lap-Dog, named Echo

IN wood and wild, ye warbling throng, Your heavy loss deplore;

Now half-extinct your powers of song,

Sweet Echo is no more.

Ye jarring, screeching things around, Scream your discordant joys;

Now half your din of tuneless sound With Echo silent lies.

Robert Burns. 
My Hoggic
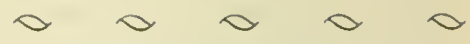

'Tune-What will I do gin my' Hoggie die?

WHAT will I do gin my lloggie die?

My joy, my pricle, my Hoggic!

My only beast, 1 had na mae, And vow but I was vogie!

The lce-lang night we watch'd the fauld, Me and my faithfu' doggic ;

We heard naught but the roaring linn, Among the braes sae scroggie;

But the howlet cry'd frae the castle wa', The blitter frae the boggie, The tod reply'd upon the hill, I trembled for my Hoggie.

When day did daw, and cocks did craw, The morning it was foggie; An' unco tyke lap o'er the dyke, And maist has kill'd my Hoggie.

Robert Burns. 
The Shepherd and his Dog $\propto$
I Y dog and I are both grown old;

On these wild downs we watch all day;

He looks in my face when the wind blows cold,

And thus methinks 1 hear him say :

The gray stone circlet is below,

The village smoke is at our feet;

We nothing hear but the sailing crow,

And wandering flocks, that roam and bleat.

Far off, the early horseman hies,

In shower or sunshine rushing on ;

Yonder the dusty whirlwind flies;

The distant coach is seen and gone.

Though solitude around is spread,

Master, alone thou shalt not be;

And when the turf is on thy head,

I only shall remember thee !

1 marked his look of faithful care,

I placed my hand on his shaggy side;

There is a sun that shines above,

A sun that shines on both, I cried.

William Lisle Bowles.

105 
Man's Conquest

(From The Animal Kingdont)

THE dog is the most complete, the most remarkable, and the most useful conquest ever made by man. Every species has become our property ; each individual is altogether devoted to his master, assumes his manners, knows and defends his property, and remains attached to him until death: and all this proceeds neither from want nor constraint, but solely from true gratitude and real friendship. The swiftness, the strength, and the scent of the dog, have created for man a powerful ally against other animals, and were perhaps necessary to the establishment of society. $\mathrm{He}$ is the only animal which has followed man through every region of the earth.

Georges Cuvier.

Beth Gêlert: or, The Grave of the Greyhound

THE spearmen heard the bugle sound,

And cheerly smil'd the morn;

And many a brach, and many a hound,

Obey'd Llewelyn's horn. 
And still he blew a louder blast,

And gave a lustier cheer ;

"Come, Gêlert, come, wert never last

Llewelyn's horn to hear." -

Oh where does faithful Gêlert roam,

The flower of all his race;

So true, so brave, a lamb at home,

"A lion in the chase"?

'T was only at Llewelyn's board

The faithful Gêlert fed;

He watch'd, he served, he cheer'd his lord,

And sentinel'd his bed.

In sooth he was a peerless hound,

The gift of royal John;

But now no Gêlert could be found,

And all the chase rode on.

And now, as o'er the rocks and dells

The gallant chidings rise,

All Snowdon's craggy chaos yells

The many-mingled cries!

That day Llewelyn little lov'd

The chase of hart and hare;

And scant and small the booty prov'd,

For Gélert was not there. 
Unpleas'd Llewelyn homeward hied ; When, near the portal seat, His truant Gêlert he espied Bounding his lord to greet.

But, when he gain'd his castle door, Aghast the chieftain stood;

The hound all o'er was smear'd with gore, His lips, his fangs, ran blood.

Llewelyn gaz'd with fierce surprise;

Unus'd such looks to meet, The favorite check'd his joyful guise, And couch'd, and lick'd his feet.

Onward, in haste, Llewelyn pass'd, And on went Gêlert too; And still, where'er his eyes he cast, Fresh blood-gouts shocked his view.

O'erturn'd his infant's bed he found, With bloodstain'd covert rent; And all around the walls and ground With recent blood besprent.

He call'd his child, no voice repliedIIe search'd with terror wild; Blood, blood he found on every sicle, But nowhere found his child. ro8 
"Hellhound! my child's by thee devour'd," The frantic father cried;

And to the hilt his vengeful sword

He plung'd in Gêlert's side.

His suppliant looks, as prone he fell,

No pity could impart ;

But still his Gêlert's dying yell

Pass'd heavy o'er his heart.

Arous'd by Gêlert's dying yell,

Some slumb'rer waken'd nigh ;-

What words the parent's joy could tell

To hear his infant's cry !

Conceal'd beneath a tumbled heap

His hurried search had miss'd, All glowing from his rosy sleep, The cherub boy he kissed.

Nor scath had he, nor harm, nor dread;

But, the same couch beneath, Lay a gaunt wolf, all torn and dead, Tremendous still in death.

Ah, what was then Llewelyn's pain!

For now the truth was clear;

His gallant hound the wolf had slain,

To save Llewelyn's heir. 
Vain, vain was all Llewclyn's woe:

"Best of thy kind, adieu!

The frantic blow which laid thee low,

This heart shall ever rue."

And now a gallant tomb they raise,

With costly sculpture deck'd ;

And marbles storied with his praise

Poor Gêlert's bones protect.

There never could the spearman pass,

Or forester, unmov'd;

There, oft the tear-besprinkled grass

Llewelyn's sorrow prov'd.

And there he hung his horn and spear,

And there, as evening fell,

In fancy's ear, he oft would hear

Poor Gêlert's dying yell.

And, till great Snowdon's rocks grow old,

And cease the storm to brave,

The consecrated spot shall hold

The name of "Gêlert's grave."

Robert William Spencer. 
The Author's Address to his Auld Dog Hector

COME, my auld, towzy, trusty friend,

What gars ye look sae dung wi' wae?

D'ye think my farour's at an end, Because thy head is turnin' gray?

Although thy strength begins to fail,

Its best was spent in serving me; An' can I grudge thy wee bit meal, Some comfort in thy age to gie?

For mony a day, frae sun to sun, We've toiled fu' hard wi' ane anither, An' mony a thousand mile thou'st run,

To keep my thraward flock thegither.

To nae thrawn boy nor naughty wife

Shall thy auld banes become a drudge;

At cats an' callans a' thy life

You ever bor'st a mortal grudge.

An' whiles thy surly look declared

Thou lo'ed the women warst of a' ; Because my love wi' thee they shared,

A matter out o' right or law.

When sittin' wi' my bonny Meg,

Mair happy than a prince could be, Thou placed'st thee by her other leg, An' watched her wi' a jealous e'e. 
$A n^{\prime}$ then at ony start or flare,

Thou wad'st hae worried furiouslye; While I was forced to curse an' swear, Afore thou wad'st forbidden be.

Yet wad she clasp thy towzy paw ;

Thy gruesome grips were never skaithly; An' thou than her hast been mair true, $A n^{\prime}$ truer than the friend that gae thee.

Ah me! o' fashion, self, an' pride,

Mankind hae read me sic a lecture ! But yet it's a' in part repaid By thee, my faithful, grateful Hector :

O'er past imprudence, oft alane

I've shed the saut an' silent tear; Then sharin' a' my grief an' pain,

My poor auld friend came snoovin' near.

For a' the days we've sojourned here, $\mathrm{An}^{\prime}$ they've been neither fine nor few, That thought possest thee year to year, That a' my griefs arose frae you.

Wi' wacsome face an' hingin' head,

Thou wad'st hae pressed thee to my knee;

While I thy looks as weel could read,

As thou had'st said in words to me ;-

\section{I 2}


"O my dear master, dinna greet ;

What hae I ever done to vex thee?

See here I'm cowrin' at your feet ;

Just take my life, if I perplex thee.

"For a' my toil, my wee drap meat

Is a' the wage I ask of thee;

For whilk I'm oft obliged to wait

W'i' hungry wame an' patient e'e.

"Whatever wayward course ye steer;

Whatever sad mischance o'ertake ye ;

Man, here is ane will hold ye dear:

Man, here is ane will ne'er forsake ye!"

Yes, my puir beast, though friends me scorn,

Whom mair than life I valued dear;

An' throw me out to fight forlorn,

IVi' ills my heart do hardly bear, -

While I hac thee to bear a part-

Iy health, my plaid, an' heczle rung,-

I'll scorn th' unfeeling haughty heart,

The saucy look, and slanderous tongue.

Some friends, by pop'lar enry swayed,

Are ten times waur than ony foe:

My heart was theirs: an' to them laid

As open as the light o' day. 
I feared my ain; but had nae dread, That I for loss o' theirs should mourn; Or that when luck an' favour fled, Their friendship wad injurious turn.

But he who feeds the ravens young, Lets naething pass he disna see; He'll sometime judge o' right an' wrong, An' aye provide for you an' me.

An' hear me, Hector, thee l'll trust,

As far as thou hast wit an' skill;

Sae will I ae sweet lovely breast,

To me a balm for every ill.

To these my trust shall never turn,

While I have reason truth to scan;

But ne'er beyond my mother's son,

To aught that bears the shape o' man.-

I ne'er could thole thy cravin' face,

Nor when ye pattit on my knee;

Though in a far an' unco place,

I've whiles been forced to beg for thee.

Even now I'm in my master's power, Where my regard can scarce be shown; But ere I'm forced to gie thee o'er,

When thou art auld an' senseless grown, 
I'll get a cottage o' my ain,

Some wee bit cannie, lonely biel', Where thy auld heart shall rest fu' fain, An' share wi' me my humble meal.

Thy post shall be to guard the door Wi' gousty bark, whate'er betides; Of cats an' hens to clear the floor, An' bite the flaes that vex thy sides.

When my last bannock's on the hearth, Of that thou sanna want thy share; While I hae house or hauld on earth, My Hector shall hae shelter there.

An' should grim death thy noddle save,

Till he has made an' end o' me; Ye'll lye a wee while on the grave $\mathrm{O}^{\prime}$ ane wha aye was kind to thee.

There's nane alive will miss me mair ;

An' though in words thou can'st not wail,

On a' the claes thy master ware,

I ken thou'lt smell an' wag thy tail.

If e'er I'm forced wi' thee to part, Which will be sair against my will; I'll sometimes mind thy honest heart, As lang as I can climb a hill. 
Come, my auld, towzy, trusty friend, Let's speed to Queensb'ry's lofty height ; All warldly cares we'll leave behind, An' onward look to days more bright.

While gazing o'er the Lowland dales,

Despondence on the breeze shall flee; $A n^{3}$ muses leave their native vales

To scale the clouds wi' you an' me. James Hogg, "The Littrick. Shepherd."

Fidelity ${ }^{1}$
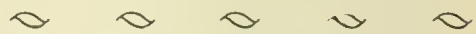

A BARKING sound the shepherd hears,

A A cry as of a $\log$ or fox;

He halts and searches with his eyes

Among the scattered rocks:

And now at distance can discern

A stirring in a brake of fern;

And instantly a dog is seen,

Glancing through that covert green.

The dog is not of mountain breed;

Its motions, too, are wild and shy;

With something, as the shepherd thinks,

Unusual in its cry :

Nor is there any one in sight

All round, in hollow or on height ;

1 Sec Helvellyn, p. 135 .

I 16 
Nor shout, nor whistle strikes his ear; What is the creature doing here?

It was a cove, a huge recess, That keeps, till June, December's snow ;

A lofty precipice in front,

A silent tarn below !

Far in the bosom of Helvellyn,

Remote from public road or dwelling,

Pathway, or cultivated land;

From trace of human foot or hand.

There sometimes doth a leaping fish Send through the tarn a lonely cheer; The crags repeat the raven's croak, In symphony austere ;

Thither the rainbow comes-the cloudAnd mists that spread the flying shroud; And sunbeams; and the sounding blast, That, if it could, would hurry past ; But that enormous barrier binds it fast.

Not free from boding thoughts, a while The shepherd stood; then makes his way Towards the dog, o'er rocks and stones, As quickly as he may;

Nor far had gone before he found A human skeleton on the ground; The appalled discoverer with a sigh Looks round, to learn the history. 
From those abrupt and perilous rocks The man had fallen, that place of fear ! At length upon the shepherd's mind It breaks, and all is clear :

He instantly recalled the name, And who he was, and whence he came; Remembered, too, the very day On which the traveller passed this way.

But hear a wonder, for whose sake This lamentable tale I tell!

A lasting monument of words This wonder merits well. The dog, which still was hovering nigh, Repeating the same timid cry, This dog had been through three months' space A dweller in that savage place.

Yes, proof was plain that since the day When this ill-fated traveller died, The dog had watched about the spot, Or by his master's side :

How nourished here through such long time He knows, who gave that love sublime; And gave that strength of fecling, great Above all human estimate.

William Wordsworth. 


\section{Incident : Characteristic of a Favourite Dog}

O his morning rounds the master Goes to learn how all things fare;

Searches pasture after pasture, Sheep and cattle eyes with care; And, for silence or for talk, He hath comrades in his walk; Four dogs, each pair of different breed, Distinguished, two for scent, and two for speed.

See a hare before him started: Off they fly in earnest chase ; Every dog is eager-hearted, All the four are in the race: And the hare whom they pursue, Hath an instinct what to do: Her hope is near: no turn she makes; But, like an arrow, to the river takes.

Deep the river was, and crusted 'Thinly by a one night's frost ; But the nimble hare hath trusted To the ice, and safely crost ; She hath crost, and without heed All are following at full speed, When, lo: the ice, so thinly spread, Breaks - and the greyhound, Dart, is over head! 
Better fate lave Prince and Swallow-

Sce them cleaving to the sport !

Music has no heart to follow,

Little Music, she stops short.

She hath neither wish nor heart,

Hers is now another part :

A loving creature she, and brave!

And fondly strives her struggling friend to save.

From the brink her paws she stretches,

Very hands as you would say!

And afficting moans she fetches,

As he breaks the ice away.

For herself she hath no fears,

IIim alone she sees and hears-

Makes efforts and complainings; nor gives o'er

Until her fellow sank, and re-appeared no more.

IVillian Worlsworth.

Tribute: To the Memory of the same Dog $\propto$

I IE here, without a record of thy worth, Beneath a covering of the common earth !

It is not from unwillingness to praise,

Or want of love, that here no stone we raise;

More thou deserv'st; but this man gives to man, Brother to brother, this is all we can. 
Yet they to whom thy virtues made thee dear Shall find thee through all changes of the year: This oak points out thy grave; the silent tree Will gladly stand a monument of thee.

I grieved for thee, and wished thy end were past ; And willingly have laid thee here at last : For thou hadst lived, till everything that cheers In thee had yielded to the weight of years; Extreme old age had wasted thee away; And left thee but a glimmering of the day; Thy ears were deaf, and feeble were thy knees, I saw thee stagger in the summer breeze, Too weak to stand against its sportive breath, And ready for the gentlest stroke of death. It came, and we were glad; yet tears were shed; Both man and woman wept when thou wert dead;

Not only for a thousand thoughts that were,

Old household thoughts, in which thou hadst thy share ;

But for some precious boons vouchsafed to thee, Found scarcely anywhere in like degrec: For love, that comes to all-the holy sense, Best gift of God-in thee was most intense; A chain of heart, a feeling of the mind, A tender sympathy, which did thee bind Not only to us men, but to thy kind: Yea, for thy fellow-brutes in thee we saw The soul of love, love's intellectual law: 
Hence, if we wept, it was not done in shame:

Our tears from passion and from reason came, And, therefore, shalt thou be an honoured name!

William Wordsworth.

The Dandy Dinmonts

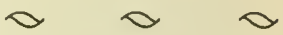

(From Guy Mannering)

A ROUGH terricr dog, his constant companion, who rivalled his master in glee, scampered at large in a thousand wheels round the heath, and came back to jump up on him, and assure him that he participated in the pleasure of the journey.

At length, when our pedestrian began to supply the wants of little Wasp, the Scotch store-farmer, for such was Mr. Dinmont, found himself at leisure to enter into conversation.

"A bonny terrier that, sir-and a fell chield at the vermin, I warrant him-that is, if he's been weel entered, for it a' lies in that."

"Really, sir," said Brown, "his education has been somewhat neglected, and his chief property is being a pleasant companion."

"Ay, sir?-that's a pity, begging your pardon -it's a great pity that-beast or body, education should aye be minded. I have six terriers at 
hame, forbye twa couple of slow-hunds, five grews, and a wheen other dogs. There's auld Pepper and auld Mustard, and young Pepper and young Mustard, and little Pepper and little Mustard. I had them a' regularly entered, first wi' rottens - then wi' stoats or weasels-and then wi' the tods and brocks-and now they fear naething that ever cam wi' a hairy skin on't."

"I have no doubt, sir, they are thorough-bredbut, to have so many dogs, you seem to have a very limited variety of names for them ?"

"O, that's a fancy of my ain to mark the breed, sir. - The Deuke himsel' has sent as far as Charlies-hope to get ane o' Dandy Dinmont's Pepper and Mustard terriers-Lord, man, he sent Tam Hudson the keeper, and siccan a day as we had wi' the foumarts and the tods, and siccan a blithe gaedown as we had again e'en! Faith, that was a night !"

- All the dogs were kicked out, excepting the venerable patriarchs, old Pepper and Mustard, whom frequent castigation and the advance of years had inspired with such a share of passive hospitality, that, after mutual explanation and remonstrance in the shape of some growling, they admitted Wasp, who had hitherto judged it safe 
to keep beneath his master's chair, to a share of a dried wedder's skin, which, with the wool uppermost and unshorn, served all the purposes of a bristol hearth-rug.

They had gradually ascended rery high, and now found themselves on a mountain ridge, overhanging a glen of great depth, but extremely narrow. Here the sportsmen had collected, with an apparatus which would have shocked a member of the Pytcheley Hunt; for, the object being the removal of a noxious and destructive animal, as well as the pleasures of the chase, poor Reynard was allowed much less fair play than when pursued in form through an open country. The strength of his habitation, however, and the nature of the ground by which it was surrounded on all sides, supplied what was wanting in the courtesy of his pursuers. The sides of the glen were broken banks of earth and rocks of rotten stone, which sunk sheer down to the little winding stream below, affording here and there a tuft of scathed brush-wood or a patch of furze. Along the edges of this ravine, which, as we have said, was very narrow, but of profound depth, the hunters on horse and foot ranged themselves; almost every farmer had with him at least a brace of large and 
fierce greyhounds, of the race of those deer-dogs which were formerly used in that country; but greatly lessened in size from being crossed with the common breed. The huntsman, a sort of provincial officer of the district, who receives a certain supply of meal, and a reward for every fox he destroys, was already at the bottom of the dell, whose echoes thundered to the chiding of two or three brace of foxhounds. Terriers, including the whole generation of Pepper and Mustard, were also in attendance, having been sent forward under the care of a shepherd. Mongrel, whelp, and cur of low degree, filled up the burden of the chorus. The spectators on the brink of the ravine, or glen, held their greyhounds in leash in readiness to slip them at the fox, as soon as the activity of the party below should force him to abandon his cover.

The scene, though uncouth to the eye of a professed sportsman, had something in it wildly captivating. The shifting figures on the mountain ridge, having the sky for their back-ground, . appeared to move in the air. The dogs, impatient of their restraint, and maddened with the baying beneath, sprung here and there, and strained at the slips, which prevented them from joining their companions. Looking down, the view was equally striking. The thin mists were not totally dispersed in the glen, so that it was often through 
their gauzy medium that the eye strove to discover the motions of the hunters below. Sometimes a breath of wind made the scene visible, the blue rill glittering as it twined itself through its rude and solitary dell. They then could see the shepherds springing with fearless activity from one dangerous point to another, and cheering the dogs on the scent, the whole so diminished by depth and distance, that they looked like pigmies. Again the mists close over them, and the only signs of their continued exertions are the halloos of the men and the clamours of the hounds, ascending as it were out of the bowels of the earth. When the fox, thus persecuted from one stronghold to another, was at length obliged to abandon his valley, and to break away for a more distant retreat, those who watched his motions from the top slipped their greyhounds, which, excelling the fox in swiftness, and equalling him in ferocity and spirit, soon brought the plunderer to his life's end.

Walter Scott. 
$\mathrm{U}^{\mathrm{P}}$ rose the sun o'er moor and mead;

Up with the sun rose Percy Rede;

Brave Keeldar, from his couples freed,

Career'd along the lea;

The palfrey sprung with sprightly bound, As if to match the gamesome hound ; His horn the gallant huntsman wound :

They were a jovial three !

Man, hound, or horse, of higher fame, To wake the wild deer never came, Since Alnwick's Earl pursued the game On Cheviot's rueful day;

Keeldar was matchless in his speed, Than Tarras ne'er was stauncher steed,

A peerless archer, Percy Rede:

And right dear friends were they.

The chase engross'd their joys and woes,

Together at the dawn they rose,

Together shared the noon's repose,

By fountain or by stream;

And oft, when evening skies were red,

The heather was their common bed,

Where each, as wildering fancy led,

Still hunted in his dream. 
Now is the thrilling moment near, Of sylvan hope and sylvan fear, Yon thicket holds the harbour'd deer,

The signs the hunters know; With eyes of flame, and quivering ears, The brake sagacious Keeldar nears; The restless palfrey paws and rears; The archer strings his bow.

The game's afoot !-Halloo! Halloo ! Hunter, and horse, and hound pursue :But woe the shaft that erring flew-

That e'er it left the string! And ill betide the faithless yew ! The stag bounds scathless o'er the dew, And gallant Keeldar's life-blood true Has drench'd the grey-goose wing.

The noble hound-he dies, he dies, Death, death has glazed his fixed eyes, Stiff on the bloody heath he lies,

Without a groan or quiver. Now day may break and bugle sound, And whoop and halloo ring around, And o'er his couch the stag may bound, But Keeldar slceps for ever.

Dilated nostrils, staring eyes, Mark the poor palfrey's mute surprise, 
He knows not that his comrade dies,

Nor what is death-but still

His aspect hath expression drear Of grief and wonder, mix'd with fear, Like startled children when they hear

Some mystic tale of ill.

But he that bent the fatal bow, Can well the sum of evil know, And o'er his favourite, bending low, In speechless grief recline;

Can think he hears the senseless clay In unreproachful accents say, "The hand that took my life away, Dear master, was it thine?

"And if it be, the shaft be bless'd, Which sure some erring aim address'd, Since in your service prized, caress'd, $I$ in your service die ; And you may have a fleeter hound, To match the dun-deer's merry bound, But by your couch will ne'er be found So true a guard as I."

And to his last stout Percy rued The fatal chance; for when he stood 'Gainst fearful odds in deadly feud,

And fell amid the fray,

K

129 
E'en with his dying voice he cried,

"Had Keeldar but been at my side,

Your treacherous ambush had been spied-

I had not died to-day!"

Remembrance of the erring bow Long since had join'd the tides which flow, Conveying human bliss and woe

Down dark oblivion's river;

But Art can Time's stern doom arrest, And snatch his spoil from Lethe's breast, And, in her Cooper's colours drest,

The scene shall live for ever.

Walter Scott.

The Hunt
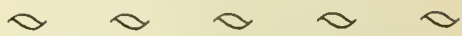

(From The Lady of the Lake)

THE stag at eve had drunk his fill, Where danced the moon on Monan's rill, And deep his midnight lair had made In lone Glenartney's hazel shade; But, when the sun his beacon red Had kindled on Benvoirlich's head, The deep-mouth'd bloodhound's heavy bay Resounded up the rocky way, And faint, from farther distance borne, Were heard the clanging hoof and horn. 
As Chief, who hears his warder call, "To arms! the foemen storm the wall," The antler'd monarch of the waste Sprung from his heathery couch in haste. But, ere his fleet career he took, The dew-drops from his flanks he shook; Like crested leader proud and high, Toss'd his beam'd frontlet to the sky ;

A moment gazed adown the dale, A moment snuff'd the tainted gale, A moment listen'd to the cry, That thicken'd as the chase drew nigh ; Then, as the headmost foes appear'd, With one brave bound the copse he clear'd, And, stretching forward free and far, Sought the wild heaths of Uam-Var.

Yell'd on the view the opening pack ; Rock, glen, and cavern, paid them back ; To many a mingled sound at once The awaken'd mountain gave response. A hundred dogs bay'd deep and strong, Clatter'd a hundred stceds along, Their peal the merry horns rung out, A hundred voices join'd the shout ; With hark and whoop and wild halloo, No rest Benvoirlich's echoes knew. Far from the tumult fled the roe, Close in her covert cower'd the doe, 
The falcon, from her cairn on high,

Cast on the rout a wondering cye, Till far beyond her piercing ken The hurricane had swept the glen. Faint, and more faint, its failing din Return'd from cavern, cliff, and linn, And silence settled, wide and still, On the lone wood and mighty hill.

Less loud the sounds of sylvan war Disturb'd the heights of Uam-Var, And roused the cavern, where, 'tis told, A giant made his den of old ; For ere that steep ascent was won, High in his pathway hung the sun, And many a gallant, stay'd perforce, Was fain to breathe his faltering horse, And of the trackers of the deer, Scarce half the lessening pack was near; So shrewdly on the mountain side Had the bold burst their mettle tried.

Alone, but with unbated zeal, That horseman plied the scourge and steel; For jaded no:w, and spent with toil, Emboss'd with foam, and dark with soil, While every gasp with sobs he drew, The labouring stag strain'd full in view. Two dogs of black Saint Hubert's breed, Unmatch'd for courage, breath, and speed, 
Fast on his flying traces came, And all but won that desperate game;

For, scarce a spear's length from his haunch, Vindictive toil'd the bloodhounds stanch;

Nor nearer might the dogs attain,

Nor farther might the quarry strain.

Thus up the margin of the lake, Between the precipice and brake, O'er stock and rock their race they take.

The Hunter mark'd that mountain high, The lone lake's western boundary, And deem'd the stag must turn to bay, Where that huge rampart barr'd the way; Already glorying in the prize, Measured his antlers with his eyes; For the death-wound and death-halloo, Muster'd his breath, his whinyard drew ; But thundering as he came prepared, With ready arm and weapon bared, The wily quarry shunn'd the shock, And turn'd him from the opposing rock; Then, dashing down a darksome glen, Soon lost to hound and hunter's ken, In the deep 'Trosachs' wildest nook His solitary refuge took. There, while close couch'd, the thicket shed Cold dews and wild-flowers on his head, He heard the baffled dogrs in vain Rave through the hollow pass amain, 
Chiding the rocks that yell'd again.

See Stumah, who, the bier beside, His master's corpse with wonder eyed, Poor Stumah! whom his least halloo Could send like lightning o'er the dew, Bristles his crest, and points his ears, As if some stranger step he hears.

The Monarch saw the gambols flag, And bade let loose a gallant stag, Whose pride, the holiday to crown, Two favourite greyhounds should pull down, That venison free, and Bordeaux wine, Might serve the archery to dine. But Lufra, - whom from Douglas' side Nor bribe nor threat could e'er divide, The fleetest hound in all the North,Brave Lufra saw, and darted forth. She left the royal hounds mid-way, And dashing on the antler'd prey, Sunk her sharp muzzle in his flank, And deep the flowing life-blood drank. The King's stout huntsman saw the sport By strange intruder broken short, Came up, and, with his leash unbound, In anger struck the noble hound.

- The Douglas had endured, that morn, The King's cold look, the nobles' scorn, 
And last, and worst to spirit proud, Had borne the pity of the crowd;

But Lufra had been fondly bred,

To share his board, to watch his bed,

And oft would Ellen Lufra's neck

In maiden glee with garlands deck;

They were such playmates, that with name

Of Lufra, Ellen's image came.

His stifled wrath is brimming high,

In darken'd brow and flashing eye;

As waves before the bark divide,

The crowd gave way before his stride;

Needs but a buffet and no more,

The groom lies senseless in his gore.

Such blow no other hand could deal,

Though gauntleted in glove of steel.

Walter Scott.

Helvellyn, r805
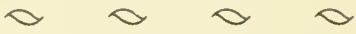

In the spring of 1805 , a young gentleman of talents, and of a most amiable disposition, perished by losing his way on the mountain Helvellyn. His remains were not discovered till three months afterwards, when they were found guarded by a faithful terricr-bitch, his constant attendant during frequent solitary rambles through the wilds of Cumberland and Westmoreland.

I CLIMIB'D the dark brow of the miglity Helvellyn, 
Lakes and mountains beneath me gleam'd misty and wide ;

All was still, save by fits, when the eagle was yelling, And starting around me the echoes replied.

On the right, Striden-edge round the Red-tarn - was bending,

And Catchedicam its left verge was defending, One huge nameless rock in the front was ascending, When I mark'd the sad spot where the wanderer had died.

Dark green was that spot 'mid the brown mountain-heather,

Where the Pilgrim of Nature lay stretch'd in decay, Like the corpse of an outcast abandon'd to weather, Till the mountain winds wasted the tenantless clay. Nor yet quite deserted, though lonely extended, For, faithful in death, his mute favourite attended, The much-loved remains of her master defended, And chased the hill-fox and the raven away.

How long didst thou think that his silence was slumber?

When the wind waved his garment, how oft diclst thou start?

How many long days and long weeks didst thou number,

Ere he faded before thee, the friend of thy heart? I 36 
And, oh! was it meet, that-no requiem read o'er him-

No mother to weep, and no friend to deplore him, And thou, little guardian, alone stretch'd before him-

Unhonour'd the Pilgrim from life should depart ?

When a Prince to the fate of the Peasant has yielded,

The tapestry waves dark round the dim-lighted hall ;

With scutcheons of silver the coffin is shieldecl, And pages stand mute by the canopied pall :

Through the courts, at deep midnight, the torches are gleaming ;

In the proudly-arch'd chapel the banners are beaming,

Far adown the long aisle sacred music is streaming, Lamenting a Chief of the people should fall.

But meeter for thee, gentle lover of nature, To lay down thy head like the meek mountain lamb,

When, wilder'd, he drops from some cliff huge in stature,

And draws his last sob by the side of his dam.

And more statcly thy couch by this lesert lake lying, 
Thy obsequies sung by the grey plover flying, With one faithful friend but to witness thy dying, In the arms of Helvellyn and Catchedicam.

W Valter Scott.

On the Death of a favourite old Spaniel

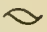

A ND they have drown'd thee then at last! poor Phillis !

The burden of old age was heavy on thee,

And yet thou should'st have lived! What though thine eye

Was dim, and watch'd no more with eager joy The wonted call that on thy dull sense sunk With fruitless repetition, the warm Sun Might still have cheer'd thy slumbers; thou didst love

To lick the hand that fed thee, and though past Youth's active season, even life itself Was comfort. Poor old friend, how earnestly Would I have pleaded for thee! thou hadst been Still the companion of my boyish sports; And as I roam'd o'er Avon's woody cliffs, From many a day-dream has thy short quick bark Recall'd my wandering soul. I have beguiled Often the melancholy hours at school, Sour'd by some little tyrant, with the thought Of distant home, and I remember'd then 
Thy faithful fondness; for not mean the joy, Returning at the happy holyday's, I felt from thy dumb welcome. Pensively Sometimes have I remark'd thy slow decay, Feeling myself changed too, and musing much On many a sad vicissitude of Life. Ah, poor companion! when thou follow'st last Thy master's parting footsteps to the gate Which closed for ever on him, thou didst lose Thy trucst friend, and none was left to plead For the old age of brute fidelity.

But fare thee well! Mine is no narrow creed; And $\mathrm{HE}$ who gave thee being did not frame The mystery of life to be the sport Of merciless man. There is another world For all that live and move . . a better one : Where the proud bipeds, who would fain confine INFINITE GOONNESS to the little bounds Of their own charity, may envy thee.

BRISTOL, 1796 .

Robert Southey.

Recognition
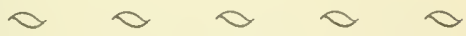

(From Roderick, the Last of the Goths)

WHILE thus Florinda spake, the dog who lay

I3efore Rusilla's fect, eyeing him long And wistfully, had recognised at length, 
Changed as he was and in those sordid weeds, His royal Master. And he rose and lick'd His wither'd hand, and earnestly look'd up With eyes whose human meaning did not need The aid of speech ; and moan'd, as if at once To court and chide the long-withheld caress.

\section{The watcliful dog}

Follow'd his footsteps close. But he retired Into the thickest grove; there yielding way To his o'erburthen'd nature, from all eyes Apart, he cast himself upon the ground, And threw his arms around the dog, and cried, While tears stream'd down, Thou, Theron, thou hast known

Thy poor lost Master, . . Theron, none but thou!

Resting his head upon his Master's knees, Upon the bank beside him Theron lay. What matters change of state and circumstance, Or lapse of years, with all their dread events, To him? What matters it that Roderick wears The crown no longer, nor the sceptre wields? . . . It is the dear-loved hand, whose friendly touch Had flatter'd him oft; it is the voice, At whose glad summons to the field so oft From slumber he had started, shaking off Dreams of the chace, to share the actual joy ; 
The eye, whose recognition he was wont To watch and welcome with exultant tongue.

Robert Southey.

\section{An Epitaph}
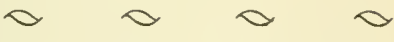

(Translated from the Latin of Lincent Bourne)

POOR Irus' faithful wolf-dog here I lie, That wont to tend my old blind master's steps,

His guide and guard : nor, while my service lasted, Had he occasion for that staff, with which He now goes picking out his path in fear Over the highways and crossings; but would plant, Safe in the conduct of my friendly string, A firm foot forward still, till he had reach'd His poor seat on some stone, nigh where the tide Of passers-by in thickest confluence flow'd : To whom with loud and passionate laments From morn to eve his dark estate he wail'd. Nor wail'd to all in vain: some here and there, The well-disposed and good, their pennies gave.

I meantime at his feet obsequious slept ; Not all-asleep in sleep, but heart and ear I'rick'cl up at his least motion, to receive At his kind hand my customary crumbs, And common portion in his feast of scraps; 
Or when night warn'd us homeward, tired and spent With our long day, and tedious beggary.

These were my manners, this my way of life, Till age and slow disease me overtook, And sever'd from my sightless master's side. But lest the grace of so good deeds should die, Through tract of years in mute oblivion lost, This slender tomb of turf hath Irus reared, Cheap monument of no ungrudging hand, And with short verse inscribed it, to attest, In long and lasting union to attest, The virtues of the Beggar and his Dog.

\section{Charles Lamb.}

That you must Love Me and Love my Dog $\propto$ (From The Essays of Elia)

"COOD sir, or madam - as it may be-we most willingly embrace the offer of your friendship. We have long known your excellent qualities. We have wished to have you nearer to us; to hold you within the very innermost fold of our heart. We can have no reserve towards a person of your open and noble nature. The frankness of your humour suits us exactly. We have been long looking for such a friend. Quick-let us disburthen our troubles into each other's bosom-let us make 
our single joys shine by reduplication. But " yap, $y$ ya, yap! "what is this confounded cur? he has fastened his tooth, which is none of the bluntest, just in the fleshy part of my leg."

"It is my dog, sir. You must love him for my sake. Here, Test-Test-Test !"

"But he has bitten me."

"Ay, that he is apt to do, till you are better acquainted with him. I have had him three years. He never bites me."

Yap, yap, yap! - "He is at it again."

"Oh, sir, you must not kick him. He does not like to be kicked. I expect my dog to be treated with all the respect due to myself."

"But do you always take him out with you, when you go a friendship-hunting?"

"Invariably. 'Tis the sweetest, prettiest, bestconditioned animal. I call him my test-the touchstone by which to try a friend. No one can properly be said to love me, who does not love him."

"Excuse us, dear sir-or madam, aforesaid-if upon further consideration we are obliged to decline the otherwise invaluable offer of your friendship. We do not like dogs."

"Mighty well, sir-you know the conditionsyou may have worse offers. Come along, Test."

Charles Lamb. 
To a Spaniel
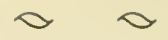

No, Daisy! lift not up thine car,

IIt is not she whose steps draw near.

Tuck under thee that leg, for she

Continues yet beyond the sea,

And thou may'st whimper in thy sleep

These many days, and start and weep.

Walter Savage Landor.

To our House-Dog "Captain"

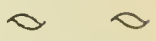

CAPTAIN! we often heretofore

Have box'd behind the coach-house door,

When thy strong paws were reared against

My ribs and bosom, badly fenc'd :

None other dared to try thy strength,

And hurl thee side-long at full length,

But we well knew each other's mind,

And paid our little debts in kind.

I often braved with boyish fist

The vanquisht bull's antagonist,

And saw unsheathed thy tiny teeth

And the dark cell that oped beneath.

Thou wert like others of the strong,

But only more averse from wrong ;

Reserved, and proud perhaps, but just,

And strict and constant to thy trust, 
Somewhat inclement to the poor, Suspecting each for evil-doer, But hearing reason when I spoke, And letting go the ragged cloak. Thee dared I : but I never dar'd

To drive the pauper from the yard.

Walter Savage Landor.

Answer to a Dog's Invitation $\curvearrowright$

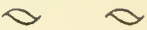

FAITHFULLEST of a faithful race, Plainly I read it in thy face

Thou wishest me to mount the stairs

And leave behind me all my cares.

No; I shall never see again

Her who now sails across the main:

Nor wilt thou ever, as before,

Rear two white feet against her door.

Therefore do thou nor whine nor roam,

But rest thee and curl round at home.

Walter Savage Landor.

Conte à Mon Chien
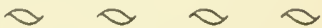

COME, my old Dog! come hither now, And rest thine head upon my knee,

And let us talk together: thou

Hath something much at heart I see.

I.

I 45 
Ay, let them laugh who understand

No utterance save of human speech-

We have a language at command

They cannot feel, we cannot teach.

Yes, thy dark eye informeth mine

With sense than words more eloquent :

Thy very ears, so long and fine,

Are flexibly intelligent.

Come hither, then, my Dog! and rest

Thy poor old head upon my knee, And tell me why, with looks distrest,

Thou eyest me so reproachfully.

Donna? the cat? Old fool! is she

The object of thy jealous fears?

Fie, Ranger! ill becometh thee

Such fancies at thy sober years.

Think'st thou that I remember not

Thy dearcr claims of days "lang syne"?

Can "auld acquaintance be forgot,"

And love, and worth, and faith like thine?

What though I smooth her velvet fur,

Whose mottled hues so finely blend?

What though I coax and fondle her?

She's but a favourite - thou my friend.

146 
And though thy ears, once glossy brown, Are faded now; though hoary white With ages' frost thy nose is grown,

And dull thy hearing and thy sight ;

And though thy once fleet limbs resign

Their spring, then light as air-blown feather;

I love thee more for every sign

That tells how long we've lived together.

And still thine ear is quick to see,

To know me yet far off : thine ear (Oh love-supplied deficiency !)

Is keen my voice, my step to hear.

And still thou com'st with wild misrule,

As in past time, to welcome me: And yet thou think'st, old jealous fool!

That that dull thing can rival thee.

Dost thou e'er hear me summon her

To be companion of my walk?

Dost thou e'er hear me talk to her,

As thou and I are wont to talk?

"But, mistress! on your lap she lies, While I am crouching at your fcet : And I've looked on with envious eyes, And seen her from your fingers eat." 
Now, my good friend! can thoughts arise So senscless in such brains as thine? Compare thine own with Donna's size, And just reflect that cats must dine.

Look at that huge thick paw-and see, Thy wrist is larger round than mine: Would'st thou a lady's nursling be ? "But, mistress! why need puss be thine?"

Because she's gentle and polite, And small, and soft, and clean withalWhilst thou, for gown of purest white, Good friend! hast no respect at all.

Thou know'st in every muddy hole 'Tis thy delight to dine and playFresh from such sport, from head to sole, You splashed me o'er but yesterday ;

While puss is always clean and sweet. "Ay, mistress! ay ! small chance have I : Your poor old servant at your feet, Despised, may lay him down and die.

"Yet I've been young, and comely too, And oft you've kissed my sleek brown head." Nay, Ranger! if you take it so,

I wish the cat were hanged and dead. 148 
There, Ranger! there ! you've won the field:

The foe's expelled; art thou at peace?

Beshrew the heart that would not yield

Indulgence e'en to love's caprice.

Have I not told thee, faithful friend!

That good and evil, joy and pain, We'll share until our journey's end?

That only death shall part us twain?

And never shall thy latter days

Know want or suffering, wrong, distress, That love, in all its countless ways,

Can remedy, relieve, redress.

And thou shalt live out all thy life-

No murderous hand shall lay thee low :

Forestalling time's more tedious strife,

With merciful, preventing blow.

Their mercy shall not end thy "pain," As they are pleased brute age to call : No, thou shalt live, old friend ! to drain Life's mingled potion, dregs and all.

And many a sweet that time defies,

Even with the latest drops shall blend, And many a comfort I'll devise

To gild thy latter days, old friend ! 
Plenteous and soft thy bed shall be,

Heaped up in basket warm and snug,

And thou shalt stretch luxuriously,

Just in the centre of the rug;

And none shall chase thee thence, nor chide

As now thy restless wanderings-no;

Scratch when thou wilt, the door flung wide

Shall yield thee passage to and fro.

Just here, thy basket they shall bring,

Before the early sunbeams fly;

Where, after many a measured ring,

Coiled up at last, thou lov'st to lie.

And never shall thy poor dim eyes

For tempting morsel ask in vainNever, if I can help it, rise

In thine old heart one jealous pain.

Well ! art thou satisfied, old friend?

Are all thy foolish fancies fled?

"Ay, mistress ! till___ I comprehend;

Till next time puss is coaxed and fed.

But come, we've worn this theme to tatters, And all my logic's thrown away; So let's discourse on other mattersAnd first-I've read a tale to-day. 
Thou know'st whate'er I see, read, learn, Relating to thy species, friend,

I tell thee, hoping it may turn To thine advantage - so attend,

My good old Ranger! while I tell

A true and mournful history, How in past time it once befell A little faithful dog like thee.

'Twas in a neighbouring land: what time The Reign of Terror triumphed there: And every horrid shape of crime,

Stalked out from murder's bloody lair :

And every fair and stately town

Became a slaughter-house and grave, Where fell proscription hunted down The good, the loyal, and the brave:

'Twas in those dreadful times there dwelt

In Lyons, the defiled with blood,

A loyal family, that felt

The earliest fury of the flood.

Wife, children, friends, it swept away

From wretched Valrive, one by one: Himself severely to stay

Till everything he loved was gone. 
A man proscribed, whom not to shun, Was danger, almost fate, to brave : So all forsook him, all save one, One humble, faithful, powerless slave,

His dog, old Nina. She had been,

When they were boys, his children's mate; His gallant Claude, his mild Eugene, Both gone before him to their fate.

And she had followed mournfully Their parting steps; and when the door Closed after them, it seemed as she Had felt they would return no more.

And when the dismal tidings came

That they had perished in their bloomBlighted, cut off without their fame, Both huddled in one bloody tomb-

And heart-struck in her first despair,

The mother sank into her grave, And Valrive, as he laid her there, Scarce wished he had the power to save;

But gazed upon that little heap, Safe shelter for the weary head, And envied her untroubled slecp, And longed to share her peaceful bed. 
Then as he stood beside the grave, With tearless eye, and lip compressed,

Crept to his feet his poor dumb slave, And moaned as if his thoughts she guessed

And looked up in his face, and sighed As if her poor old heart would break ; And in her fond mute language cried, "Oh, master! live for Nina's sake."

They spurned her off-but ever more,

Surmounting e'en her timid nature, Love brought her to the prison door,

And there she crouched, fond, faithful creature!

Watching so long, so piteously,

That e'en the jailer-man of guilt, Of rugged heart-was moved to cry,

"Poor wretch! there enter, if thou wilt."

And who than Nina more content,

When she had gained that dreary cell,

Where lay in helpless dreariment

The master loved so long and well!

And when into his arms she leapt,

In her old fond, familiar way, And close into his bosom crept, And licked his face-a feeble ray 
Of something - not yet comfort-stole

Upon his heart's stern misery ;

And his lips moved, "Poor loving fool!

Then all have not abandoned me."

The hour by grudging kindness spared

Expired too soon - the friends must part-

And Nina from the prison fared,

With lingering pace and heavy heart.

Shelter, and rest, and food she found

With one who, for the master's sake,

Though grim suspicion stalked around,

Dared his old servant home to take.

Beneath that friendly roof each night

She stayed, but still returning day-

Ay, the first beam of dawning light-

Beheld her on her anxious way

Towards the prison, there to wait

The hour, when through that dismal door

The keeper, half compassionate,

Should bid her enter as before.

And well she seemed to comprehend

The time apportioned for her stay:

The little hour that with her friend

She tarried then, was all her day. 
But what an age of love, and grief, And confidence, was crowded in it!

How many a long, long life is brief,

Compared with such a heart-fraught minute!

Nethinks, old Ranger, thou and I

Can fancy all they thought and said-

Believ'd thou not, of days gone by

Their hearts communed, and of the dead ?

Ay, on my life !-And Valrive spoke

(The childless father!) of his boys

To their old playmate, and awoke

The memory of their infant joys.

For ever thus, when in their prime

A parent's hopes in dust are laid,

His heart recurs to that sweet time

When, children, round his knees they played.

So oft in Nina's ear was breathed

The names of those belovèd ones, And hers, who could not live bereaved

Of both her children. Many suns

Went down upon the dreary pile

Where Valrive lay-and evermore,

Punctual as light's returning smile,

Came Nina to the prison door. 
At last the captive's summons came :

They led him forth his doom to hear;

No tremor shook his thrice-nerved frame,

Whose heart was dead to hope and fear.

So with calm step he moved along, And calmly faced the murderous crew ; But close and closer for the throng, Poor Nina to her master grew.

And she has found a resting place

Between his knees-her old safe homeAnd she looks round in every face

As if to read his written doom.

There is no mercy but above-

The word goes fortl - the fatal breath-

Does instinct, or more powerful Love,

Tell thee, poor brute! that word is death?

Howe'er informed, a child might see

The sentence struck upon her heart, And that her eye's keen misery

Said, "Master! we will never part!"

'Twas but a step, in those dread days,

From trial to the guillotine-

A moment-and Valrive surveys,

With steadfast eye, the fell machine.

$$
\text { I } 56
$$


He mounts the platform-takes his stand Before the fatal block, and kneels In preparation-but his hand A soft warm touch that moment feels.

His eyes glance downward, and a tearThe last tear they shall ever shedFalls as he utters "Thou still here!" Upon his faithful servant's head.

Yes-she is there! that hellish shout, That deadly stroke, she hears them plain, And from the headless trunk starts out, Even over her, the bloody rain.

And she beholds where they have cast

(Uncoffined, bleeding yet, and warm, His shallow grave filled up in haste Without a prayer) that mangled form.

But where is all the tumult now?

That horrid engine, blood-imbrued, That corse yet quivering with the blow, That gazing, shouting multitude?

All passed away - all vanished - gone-

Even like a vision seen in sleep! And in its stead, lies all alone A dog beside a fresh turned heap. 
Old faithful Nina! there lies she,

Her cold head on the cold earth pressed,

As it was wont so lovingly

To lie upon her master's breast.

And there she stayed the livelong day,

Mute, motionless, her sad watch keeping;

A stranger who had passed that way,

IVould have believed her dead or sleeping.

But if a step approached the grave,

Her eye looked up with jealous care Imploringly, as if to crave

That no rude foot should trample there.

That night she came not as of late

To her old charitable home :

The next day's sun arose and set,

Night fell-and still she failed to come.

Then the third day her pitying host

Went kindly forth to seek his guest,

And found her at her mournful post

Stretched quietly, as if at rest.

Yet she was not asleep nor dead;

And when her master's friend she saw, The poor old creature raised her head, And moaned, and moved one feeble paw. 
But stirred not thence-and all in vain

He called, caressed her, would have ledTried threats - then coaxing words againBrought food-she turned away her head.

So with kind violence at last

He bore her home: with gentle care In her old shelter tied her fast, Placed food beside, and left her there.

But ere the hour of rest, again

He visited the captive's shed, And there the cord lay, gnawed in twainThe food untasted-she was fled.

And, vexed, he cried, "Perverse old creature :

Well, let her go, I've done my best." But there was something in his nature,

A feeling would not let him rest.

So, with the early light, once more

Towards the burial-ground went he; And there he found her as before, But not as then stretched quietly.

For she had worked the long night through,

In the strong impulse of despair, Down, down into the grave-and now, l'anting and weak, still laboured there. 
But death's cold stiffening frost benumbs

Her limbs, and clouds her heavy eyeAnd hark: her feeble moan becomes

A shriek of human agony.

As if before her task was over

She feared to die in her despair-

But see! those last faint strokes uncover

A straggling lock of thin grey hair.

One struggle! one convulsive start!

And there the face beloved lies-

Now be at peace, thou faithful heart!

She licks the livid lips, and dies.

Caroline Bowles Southey.

"Boatswain's" Epitaph

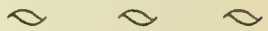

$N_{\text {Ear this spot }}$

Are deposited the Remains of one

Who possessed Beauty without Vanity,

Strength without Insolence,

Courage without Ferocity,

And all the Virtues of Man without his Vices.

This Praise, which would be unmeaning Flattery

If inscribed over human ashes,

Is but a just tribute to the Memory of

I 60 
Boatswain, a Dog,

Who was born at Newfoundland, May i 803 , And died at Newstead Abbey, Nov, I8, I 808.

\section{EPITAPH}

When some proud son of man returns to earth, Unknown to glory, but upheld by birth, The sculptor's art exhausts the pomp of woe, And storied urn records who rest below; When all is done, upon the tomb is seen, Not what he was, but what he should have been: But the poor dog, in life the firmest friend, The first to welcome, the foremost to defend, Whose honest heart is still his master's own, Who labours, fights, lives, breathes for him alone, Unhonour'd falls, unnoticed all his worth, Denied in heaven the soul he held on earth : While man, vain insect! hopes to be forgiv'n, And claims himself a sole exclusive heaven. Oh, man ! thou feeble tenant of an hour, Debas'd by slav'ry or corrupt by power, Who knows thee well must quit thee with disgust; Degraded mass of animated dust!

Thy love is lust, thy friendship all a cheat, Thy smiles hypocrisy, thy words deceit! By nature vile, ennobled but by name, Each kindred brute might bid thee blush for shame. Ye ! who perchance behold this simple urn, 
Pass on -it honours none you wish to mourn: To mark a fricnd's remains these stones arise ;

I never knew but one,-and here he lies. George Gordon Noel hyron.

NewSTEAd ABBEY, November $30,1808$.

The Bagman's Dog $\diamond \propto \propto \propto$ Stant littore Puppies!-Virgil.

$\mathrm{T}$ was a litter, a litter of five,

1 Four are drown'd, and one left alive,

He was thought worthy alone to survive; And the Bagman resolved upon bringing him up, To eat of his bread and drink of his cup, He was such a dear little cock-tail'd pup ! The Bagman taught him many a trick; He would carry, and fetch, and run after a stick, Could well understand The word of command, And appear to doze With a crust on his nose Tiil the Bagman permissively waved his hand: Then to throw up and catch it he never would fail, As he sat up on end, on his little cock-tail. Never was puppy so bien instruit, Or possess'd of such natural talent as he ;

And as he grew older, Every beholder Agreed he grew handsomer, sleeker, and bolder 162 
Time, however, his wheels we may clog,

Wends steadily still with onward jog,

And the cock-tail'd puppy's a curly-tail'd dog !

When, just at the time He was reaching his prime, And all thought he'd be turning out something sublime,

One unlucky day, How, no one could say,

Whether soft liaison induced him to stray,

Or some kidnapping vagabond coax'd him away,

He was lost to the view, Like the morning dew ;$\mathrm{He}$ had been, and was not-that's all that they knew ;

And the Bagman storm'd, and the Bagman swore As never a Bagman has sworn before;

But storming or swearing but little avails To recover lost dogs with great curly tails.

\section{Thomas Ingoldsby.}

The Sociable Cur
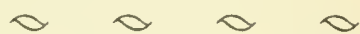

(From Trevelyan's Life of Lord Macaulay)

January $3 \mathrm{x}, 1856$ or 1857 ?

A FTER lunch 1 went to walk alone in the pleasure-ground [at Bowood], but was pestered by a most sociable cur who would not be got rid of. I went into a plantation, railed off $16_{3}$ 
with gates at each end, and shut the brute out: but he perfectly understood my tactics - curse his intelligence!-and waited for me at the other gate. After vainly trying to escape him in this way, I shut him in, and stayed outside myself. When I walked atway, he saw that he had been out-generalled by human reason, and set up the most ludicrous howl that I ever heard in my life.

In 1850 Lord Macaulay writes :-

How odd that people of sense should find any pleasure in being accompanied by a beast who is always spoiling conversation.

To Flush, my Dog $\propto \propto \propto \propto$

I OVING friend, the gift of one

L Who her own true faith has run

Through thy lower nature, ${ }^{1}$

Be my benediction said

With my hand upon thy head,

Gentle fellow-creature!

1 This dog was the gift of my dear and admired friend, Miss Mitford, and belongs to the beautiful race she has rendered celebrated among English and American readers. The Flushes have their laurels as well as the Cosars, the chief difference (at least the very head and front of it) consisting, perhaps, in the bald head of the latter under the crown. -1844 . 
Like a lady's ringlets brown, Flow thy silken ears adown Either side demurely Of thy silver-suited breast, Shining out from all the rest Of thy body purely.

Darkly brown thy body is, Till the sunshine striking this Alchemise its dulness, When the sleek curls manifold Flash all over into gold

With a burnished fulness.

Underneath my stroking hand, Startled eyes of hazel bland

Kindling, growing larger, Up thou leapest with a spring, Full of prank and curveting,

Leaping like a charger.

Leap! thy broad tail waves a light, Leap ! thy slender feet are bright,

Canopied in fringes;

Leap! those tasselled cars of thine Flicker strangely, fair and fine

Down their golden inches.

Yet, my pretty, sportive friend,

Little is't to such an end

That I praise thy rareness; 165 
Other dogs may be thy peers Haply in these drooping cars And this glossy fairness.

But of thee it shall be said, This dog watched beside a bed Day and night unweary, Watched within a curtained room Where no sunbeam brake the gloom

Round the sick and dreary.

Roses, gathered for a vase, In that chamber died apace,

Beam and breeze resigning ;

This dog only, waited on, Knowing that when light is gone

Love remains for shining.

Other dogs in thymy dew Tracked the hares and followed through

Sunny moor or meadow ;

This dog only, crept and crept

Next a languid cheek that slept,

Sharing in the shadow.

Other dogs of loyal cheer Bounded at the whistle clear,

Up the woodside hieing; This dog only, watched in reach

Of a faintly uttered speech

Or a louder sighing. 
And if one or two quick tears Dropped upon his glossy ears Or a sigh came double, Up he sprang in eager haste, Fawning, fondling, breathing fast, In a tender trouble.

And this dog was satisfied If a pale thin hand would glide Down his dewlaps sloping,Which he pushed his nose within, After,-platforming his chin On the palm left open.

This dog, if a friendly voice Call him now to blither choice

Than such chamber-keeping, "Come out!" praying from the door,Presseth backward as before,

Up against me leaping.

Therefore to this $\operatorname{dog}$ will 1 , Tenderly not scornfully,

Render praise and favour: With my hand upon his head, Is my benediction said

Therefore and for ever. And because he loves me so, Better than his kind will do

Often man or woman, 
Give I back more love again

Than dogs often take of men,

Leaning from my Human.

Blessings on thee, dog of mine, Pretty collars make thee fine,

Sugarcd milk make fat thee !

Pleasures wag on in thy tail,

Hands of gentle motion fail

Nevermore, to pat thee!

Downy pillow take thy head, Silken coverlid bestead,

Sunshine help thy sleeping ! No fly's buzzing wake thee up, No man break thy purple cup

Set for drinking deep in.

Whiskered cats arointed flee, Sturdy stoppers keep from thee

Cologne distillations;

Nuts lie in thy path for stones, And thy feast-day macaroons

Turn to daily rations!

Mock I thee, in wishing weal ?-

Tears are in my eyes to feel

Thou art made so straitly,

Blessing needs must straiten too, -

Little canst thou joy or do,

Thou who lovest greatly. 
Yet be blessèd to the height Of all good and all delight

Pervious to thy nature;

Only loved beyond that line,

With a love that answers thine,

Loving fellow-creature!

Elizabeth Barrett Browning.

Flush or Faunus

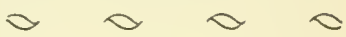

YOU see this dog; it was but yesterday I mused forgetful of his presence here,

Till thought on thought drew downward tear on tear :

When from the pillow where wet-cheeked I lay, A head as hairy as Faunus thrust its way Right sudden against my face, two golden-clear Great eyes astonished mine, a drooping ear Did flap me on either cheek to dry the spray! I started first as some Arcadian Amazed by goatly god in twilight grove : But as the bearded vision closelier ran My tears off, I knew Flush, and rose above Surprise and sadness, - thanking the true PAN Who by low creatures leads to heights of love. Elizabeth barrett Browning. I 69 
(From The Expression of the Emotions in Man and Animals)

DOGS, when they wish to go to sleep on a carpet or other hard surface, generally turn round and round and scratch the ground with their fore-paws in a senseless manner, as if they intended to trample down the grass and scoop out a hollow, as no doubt their wild parents did, when they lived on open grassy plains or in the woods.

Charles Darwin.

Shepherd Dogs
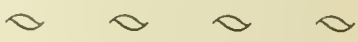

(From The Voyage of the Beagle)

While staying at this estancia [Banda Oriental], I was amused with what I saw and heard of the shepherd dogs of the country. When riding, it is a common thing to meet a large flock of sheep guarded by one or two dogs, at the distance of some miles from any house or man. I have often wondered how so firm a friendship had been established. The method of education consists in separating the puppy, while very young, from the bitch, and in accustoming it to its future companions. An ewe is held three 
or four times a day for the little thing to suck, and a nest of wool is made for it in the sheep-pen ; at no time is it allowed to associate with other dogs, or with the children of the family. The puppy is, moreover, generally castrated; so that, when grown up, it can scarcely have any feelings in common with the rest of its kind. From this education it has no wish to leave the flock, and just as another dog will defend its master, man, so will these the sheep. It is amusing to observe, when approaching a flock, how the dog immediately advances barking, and the sheep all close in his rear, as if round the oldest ram. These dogs are also easily taught to bring home the fock, at a certain hour in the evening. Their most troublesome fault, when young, is their desire of playing with the sheep; for in their sport they sometimes gallop their poor subjects most unmercifully.

Charles Darwin.

Our Dogs
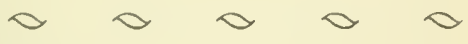

(From Hore Subseciva)

\section{IV asp}

VIAS a dark brindled bull-terrier, as pure in blood as Cruiser or Wild Dayrell. She was brought by my brother from Otley, in the West Riding. She was very handsome, fierce, 
and gentle, with a small, compact, finely-shaped head, and a pair of wonderful eyes-as full of fire and of softness as Grisi's; indeed she had to my eye a curious look of that wonderful genius-at once wild and fond. It was a fine sight to see her on the prowl across Bowden Moor, now cantering with her nose down, now gathered up on the top of a dyke, and with erect ears, looking across the wild like a moss-trooper out on business, keen and fell. She could do everything it became a dog to do, from killing an otter or a pole-cat, to watching and playing with a baby, and was as docile to her master as she was surly to all else. She was not quarrelsome, but "being in" she would have pleased Polonius as much, as in being "ware of entrance." She was never beaten, and she killed on the spot scveral of the country bullies who came out upon her when following her master in his rounds. She generally sent them off howling with one snap, but if this was not enough, she made an end of it.

But it was as a mother that she shone; and to see the gipsy, Hagar-like creature nursing her occasional Ishmael_-playing with him, and fondling him all over, teaching his teeth to war, and with her eye and the curl of her lip daring any one but her master to touch him, was like seeing Grisi watching her darling "Gennaro," who so little knew why and how much she loved him. 
Once when she had three pups, one of them died. For two days and nights she gave herself up to trying to bring it to life-licking it, and turning it over and over, growling over it, and all but worrying it to awake it. She paid no attention to the living two, gave them no milk, flung them away with her teeth, and would have killed them, had they been allowed to remain with her. She was as one possessed, and neither ate, nor drank, nor slept, was heavy and miserable with her milk, and in such a state of excitement that no one could remove the dead pup.

Early on the third day she was seen to take the pup in her mouth, and start across the fields towards the Tweed, striding like a race-horseshe plunged in, holding up her burden, and at the middle of the stream dropped it, and swam swiftly ashore: then she stood and watched the little dark lump floating away; bobbing up and down with the current, and losing it at last far down, she made her way home, sought out the living two, devoured them with her love, carried them one by one to her lair, and gave herself up wholly to nurse them: you can fancy her mental and bodily happiness and relief when they were pulling away-and theirs.

On one occasion my brother had lent her to a woman who liverl in a lonely house, and whose husband was away for a time. She was a capital 
watch. One day an Italian with his organ camefirst begging, then demanding money-showing that he knew she was alone, and that he meant to help himself, if she didn't. She threatened to "lowse the dowg"; but as this was Greek to him, he pushed on. She had just time to set Wasp at him. It was very short work. She had him by the throat, pulled him and his organ down with a heavy crash, the organ giving a ludicrous sort of cry of musical pain. Wasp, thinking this was from some creature within, possibly a whittret, left the ruffian, and set to work teeth and nail on the box. Its master slunk off, and with mingled fury and thankfulness, watched her disembowelling his only means of an honest living. The woman good-naturedly took her off, and signed to the miscreant to make himself and his remains scarce. This he did with a scowl; and was found in the evening in the village, telling a series of lies to the watchmaker, and bribing him with a shilling to mend his pipes— "his kist o' whussels."

\section{Duchie}

Her oddities werc endless. We had and still have a dear friend,_- "Cousin Susan" she is called by many who are not her cousins-a perfect lady, and, though hopclessly deaf, as gentle and contented as ever Griselda with the full use of her 
ears, quite as great a pet, in a word, of us all as Duchie was of ours. One day we found her mourning the death of a cat, a great playfellow of the Sputchards', and her small Grace was with us when we were condoling with her, and we saw that she looked very wistfully at Duchie. I wrote on the slate, "Would you like her?" and she through her tears said, "You know that would never do." But it did do. We left Duchie that very night, and though she paid us frequent visits, she was Cousin Susan's for life. I fear indulgence dulled her moral sense. She was an immense happiness to her mistress, whose silent and lonely days she made glad with her oddity and mirth. And yet the small creature, old, toothless, and blind, domineered over her gentle friend-threatening her sometimes if she presumed to remove the small Fury from the inside of her own bed, into which it pleased her to creep. Indeed, I believe it is too true, though it was inferred only, that her mistress and friend spent a great part of a winter night in trying to coax her dear little ruffian out of the centre of the bed. One day the cook asked what she would have for dinner: "I would like a mutton chop, but then, you know, Duchie likes minced veal better!" The faithful and happy little creature died at a great age of natural decay. 


\section{John Pym}

John Pym was a smaller dog than Crab, of more fashionable blood, being a son of Mr. Sommer's famous SHEM, whose father and brother are said to have been found dead in a drain into which the hounds had run a fox. It had three entrances; the father was put in at one hole, the son at another, and speedily the fox bolted out at the third, but no appearance of the little terriers, and, on digging, they were found dead, locked in each other's jaws; they had met, and it being dark, and there being no time for explanations, they had throttled each other. John was made of the same sort of stuff, and was as combative and victorious as his great namesake, and not unlike him in some of his not so creditable qualities. He must, I think, have been related to a certain dog to whom "life was full o' sairiousness," but in John's case the same cause produced an opposite effect. John was gay and light-hearted, even when there was not "enuff o' fechtin," which, however, seldom happened, there being a market every week in Melrose, and John appearing most punctually at the cross to challenge all comers, and being short legged, he inveigled every dog into an engagement by first attacking him, and then falling down on his back, in which posture he latterly fought and won all his battles. 
What can I say of PUCK ${ }^{2}$ - the thoroughbred - the simple-hearted-the purloiner of eggs warm from the hen-the flutterer of all manner of Volscians - the bandy-legged, dear, old, dilapidated buffer? I got him from my brother, and only parted with him because William's stock was gone. He had to the end of life a simplicity which was quite touching. One summer day-a dog daywhen all dogs found straying were hauled away to the police-office, and killed off in twenties by strychnine, I met Puck trotting along Princes Street with a policeman, a rope round his neck, he looking up in the fatal, official, but kindly countenance in the most artless and cheerful manner, wagging his tail and trotting along. In ten minutes he would have been in the next world; or $1 \mathrm{am}$ one of those who believe dogs have a next world, and why not? Puck ended his days as the best dog in Roxburghshire. Placide quiescas!

\section{Dick}

Still lives, and long may he live! As he was never born, possibly he may never die; be it so, he will miss us when we are gone. I could say much of him, but agree with the lively and admirable Dr. Jortin, when, in his dedication of his Remarks on Ecclesiastical History to the then (1752) Archbishop of Canterbury, he excuses

1 Dandie Dinmont. 
himself for not following the modern custom of praising his Patron, by reminding his Grace "that it was a custom amongst the ancients, not to sacrifice to heroes till after sunset." I defer my sacrifice till Dick's sun is set.

I think every family should have a dog; it is like having a perpetual baby; it is the plaything and crony of the whole house. It keeps them all young. All unite upon Dick. And then he tells no tales, betrays no secrets, never sulks, asks no troublesome questions, never gets into debt, never coming down late for breakfast, or coming in by his Chubb too early to bed-is always ready for a bit of fun, lies in wait for it, and you may, if choleric, to your relief, kick him instead of some one else, who would not take it so meekly, and, moreover, would certainly not, as he does, ask your pardon for being kickcd. Never put a collar on your dog-it only gets him stolen; give him only one meal a day, and let that, as Dame Dorothy, Sir Thomas Browne's wife, would say, be "rayther under." Wash him once a week, and always wash the soap out; and let him be carefully combed and brushed twice a week.

By the bye, I was wrong in saying that it was Burns who said Man is the God of the Dog-he got it from Bacon's Essay on Atheism, or perhaps more truly-Bacon had it first.

John Brown. 
(Lately run over, after having gone through the Crimean Campaign)

GO lift him gently from the wheels, And soothe his dying pain, For love and care e'en yet he feels Though love and care be vain; 'Tis sad that, after all these years, Our comrade and our friend, The brave dog of the Fusiliers, Should meet with such an end.

Up Alma's hill, among the vines, We laughed to see him trot, Then frisk along the silent lines,

To chase the rolling shot :

And, when the work waxed hard by day,

And hard and cold by night ;

When that November morning lay

Upon us, like a blight,

And eyes were strained, and ears were bent,

Against the muttering north,

Till the grey mist took shape, and sent

Grey scores of Russians forth-

Beneath that slaughter wild and grim,

Nor man nor dog would run;

lle stood by us, and we by him,

Till the great fight was done. 
And right throughout the snow and frost

He faced both shot and shell;

Though unrelieved, he kept his post,

And did his duty well.

By death on death the time was stained,

By want, disease, despair ;

Like autumn leaves our army waned,

But still the dog was there:

He cheered us through those hours of gloom ;

We fed him in our dearth ;

Through him the trench's living tomb

Rang loud with reckless mirth;

And thus, when peace returned once more,

After the city's fall,

That veteran home in pride we bore,

And loved him, one and all.

With ranks re-filled, our hearts were sick,

And to old memories clung ;

The grim ravines we left glared thick

With death-stones of the young.

Hands which had patted him lay chill,

Voices which called were dumb,

And footsteps that he watched for still

Never again could come.

Never again; this world of woe Still hurries on so fast :

180 
They come not back, 'tis he must go

To join them in the past:

There, with brave names and deeds entwined,

Which Time may not forget,

Young Fusiliers unborn shall find

The legend of our pet.

Whilst o'er fresh years, and other life

Yet in God's mystic urn,

The picture of the mighty strife

Arises sad and stern-

Blood all in front, behind far shrines

With women weeping low,

For whom each lost one's fane but shines,

As shines the moon on snow-

Marked by the medal, his of right,

And by his kind keen face,

Under that visionary light

Poor Bob shall keep his place;

And never may our honoured Queen

For love and service pay,

Less brave, less patient, or more mean

Than his we mourn to-day!

Francis Doyle 


\section{Jerry's Dogs $\propto \propto$
(From The Old Curiosity Shop)}

THESE were no other than four very dismal other, headed by an old bandy dog of particularly mournful aspect, who, stopping when the last of his followers had got as far as the door, erected himself upon his hind legs and looked round at his companions, who immediately stood upon their hind legs, in a grave and melancholy row. Nor was this the one remarkable circumstance about these dogs, for each of them wore a kind of little coat of some gaudy colour trimmed with tarnished spangles, and one of them had a cap upon his head, tied very carefully under his chin, which had fallen down upon his nose and completely obscured one eye; add to this, that the gaudy coats were all wet through and discoloured with rain, and that the wearers were splashed and dirty, and some idea may be formed of the unusual appearance of these new visitors to the Jolly Sandboys.

Neither Short nor the Landlord nor Thomas Codlin, however, was in the least surprised, merely remarking that these were Jerry's dogs, and that Jerry could not be far behind. So 182 
there the dogs stood, patiently winking and gaping and looking extremely hard at the boiling pot, until Jerry himself appeared, when they all dropped down at once and walked about the room in their natural manner. This posture it must be confessed did not much improve their appearance, as their own personal tails and their coat tails-both capital things in their way-did not agree together.

Jerry, the manager of these dancing dogs, was a tall black-whiskered man in a velveteen coat, who seemed well known to the Landlord and his guests, and accosted them with great cordiality. Disencumbering himself of a barrel organ which he placed upon a chair, and retaining in his hand a small whip wherewith to awe his company of comedians, he came up to the fire to dry himself, and entered into conversation.

"Your people don't usually travel in character, do they ?" said Short, pointing to the dresses of the dogs. "It must come expensive if thcy do?"

"No," replied Jerry, "no, it's not the custom with us. But we've been playing a little on the road to-day, and we come out with a new wardrobe at the races, so I didn't think it worth while to stop to undress. Down, l'edro !"

This was addressed to the dog with a cap on, who being a new member of the company, and not quite certain of his duty, kept his unobscured 183 
eye anxiously on his master, and was perpetually starting upon his hind legs when there was no occasion, and falling down again.

"I've got a animal here," said Jerry, putting his hand into the capacious pocket of his coat, and diving into one corner as if he were feeling for a small orange or an apple or some such article, "a animal here, wot 1 think you know something of, Short."

"Ah !" cried Short, "let's have a look at him."

"Here he is," said Jerry, producing a little terrier from his pocket. "He was once a Toby of yours, warn't he?"

In some versions of the great drama of Punch there is a small dog-a modern innovationsupposed to be the private property of that gentleman, whose name is always Toby. This Toby has been stolen in youth from another gentleman, and fraudulently sold to the confiding hero, who having no guile himself has no suspicion that it lurks in others; but Toby, entertaining a grateful recollection of his old master, and scorning to attach himself to any new patrons, not only refuses to smoke a pipe at the bidding of Punch, but to mark his old fidelity more strongly, seizes him by the nose and wrings the same with violence, at which instance of canine attachment the spectators are deeply affected. This was the character which the little terrier in question had I 84 
once sustained; if there had been any doubt upon the subject he would speedily have resolved it by his conduct; for not only did he, on seeing Short, give the strongest tokens of recognition, but catching sight of the flat box he barked so furiously at the pasteboard nose which he knew was inside, that his master was obliged to gather him up and put him into his pocket again, to the great relief of the whole company.

The Landlord now busied himself in laying the cloth, in which process Mr. Codlin obligingly assisted by setting forth his own knife and fork in the most convenient place and establishing himself behind then. When everything was ready, the Landlord took off the cover for the last time, and then indeed there burst forth such a goodly promise of supper, that if he had offered to put it on again or had hinted at postponement, he would certainly have been sacrificed on his own hearth.

However, he did nothing of the kind, but instead thereof assisted a stout servant girl in turning the contents of the cauldron into a large tureen; a proceeding which the dogs, proof against various hot splashes which fell upon their noses, watched with terrible eagerness. At length the dish was lifted on to the table, and mugs of ale having been previously set round, little Nell ventured to say grace, and supper began. 
At this juncture the poor dogs were standing on their hind legs quite surprisingly; the child, having pity on them, was about to cast some morsels of food to them before she tasted it herself, hungry though she was, when their master interposed.

"No, my dear, no, not an atom from anybody's hand but mine if you please. That dog," said Jerry, pointing out the old leacler of the troop, and speaking in a terrible voice, "lost a halfpenny to-day. He goes without his supper."

The unfortunate creature dropped upon his fore-legs directly, wagged his tail, and looked imploringly at his master.

"You must be more careful, sir," said Jerry, walking coolly to the chair where he had placed the organ, and setting the stop. "Come here. Now, sir, you play away at that, while we have supper, and leave off if you dare."

The dog immediately began to grind most mournful music. His master having shown him the whip resumed his seat and called up the others, who, at his directions, formed in a row, standing upright as a file of soldiers.

"Now, gentlemen," said Jerry, looking at them attentively. "The dog whose name's called, eats. The dogs whose names an't called, keep quiet. Carlo!"

The lucky individual whose name was called, I 86 
snapped up the morsel thrown towards him, but none of the others mored a muscle. In this manner they were fed at the discretion of their master. Meanwhile the dog in disgrace ground hard at the organ, sometimes in quick time, sometimes in slow, but never leaving off for an instant. When the knives and forks rattled very much, or any of his fellows got an unusually large piece of fat, he accompanied the music with a short howl, but he immediately checked it on his master looking round, and applied himself with increased diligence to the Old Hundredth.

Charles Dickens.

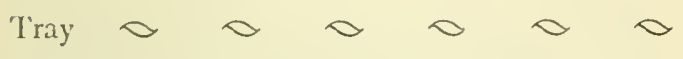

\section{SING me a hero: Quench my thirst \\ Of Soul, ye bards !}

Quoth Bard the first:

"Sir Olaf, the good knight, did don His helm and eke his habergeon"... Sir Olaf and his bard-!

"That sin-scathed brow" (quoth Bard the second), "That eye wide ope as though Fate beckoned My hero to some steep, beneath Which precipice smiled tempting death . . . You too without your host have reckoned!" 
"A beggar-child" (let's hear this third!)

"Sat on a quay's edge : like a bird Sang to herself at careless play,

And fell into the stream. 'Dismay!

Help, you the standers-by!' None stirred.

"Bystanders reason, think of wives And children ere they risk their lives.

Over the balustrade has bounced

A mere instinctive dog, and pounced Plumb on the prize. 'How well he dives!

" 'Up he comes with the child, see, tight In mouth, alive too, clutched from quite A depth of ten feet-twelve, I bet ! Good dog! What, off again? There's yet Another child to save? All right!

" 'How strange we saw no other fall: It's instinct in the aninal.

Good dog ! But he's a long while under: If he got drowned I should not wonderStrong current, that against the wall !

" "Here he comes, holds in mouth this time -What may the thing be? Well, that's prime!

Now, did you ever? Reason reigns

In man alone, since all Tray's pains

Have fished-the child's doll from the slime!'

I 88 
"And so, amid the laughter gay,

Trotted my hero off,-old Tray,-

Till somebody, prerogatived

With reason, reasoned: "Why he dived,

His brain would show us, 1 should say.

" "John, go and catch-or, if needs be,

Purchase-that animal for me :

By vivisection, at expense

Of half-an-hour and eighteenpence,

How brain secretes dog's soul, we'll see!'”

Robert Browning.

Inscription on a Dog's Tomb $\prec$

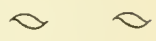

Louis

Died Sept. I 7, 1854

TO cold philosophy, nor cynic sneer,

1 Checks the unbidden and the honest tear

What little difference, and how short the span,

Betwixt thy instinct and the mind of man : 
(From Adam Bede)

THE moment he appeared at the kitchen door 1 with the candle in his hand, a faint whimpering began in the chimney-corner, and a brownand-tan-coloured bitch, of that wise-looking breed with short legs and long body, known to an unmechanical generation as turnspits, came creeping along the floor, wagging her tail, and hesitating at every other step, as if her affections were painfully divided between the hamper in the chimney-corner and the master, whom she could not leave without a greeting.

"Well, Vixen, well then, how are the babbies?" said the schoolmaster, making haste towards the chimney-corner, and holding the candle over the low hamper, where two extremely blind puppies lifted up their heads towards the light, from a nest of flannel and wool. Vixen could not even see her master look at them without painful excitement : she got into the hamper and got out again the next moment, and behaved with true feminine folly, though looking all the while as wise as a dwarf with a large old-fashioned head and body on the most abbreviated legs.

George Eliot. 


\section{Proverbial Saying}
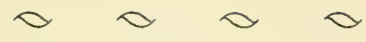

I $F$ you will have a good tike, Of which there are few like,

He must be beaded like a Snake,

Neckt like a Drake,

Backt like a Beam,

Sided like a Bream,

Tayled like a Rat

And footed like a Cat.

Proverbs
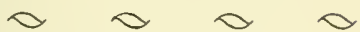

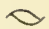

T ET sleeping dogs lie.

Live a dog a bad name and hang him.

Love me love my dog.

A Woman, a dog, and a walnut tree, the more you bang 'em, the better they be.

Any stick is good enough to beat a dog.

You can't teach an old dog new tricks.

You can't take butter out of a dog's mouth.

A dog winna yowl if ye fell him wi' a bane.

An ill hound comes halting hame.

Better a dog fawn nor bark at you.

Fiddlers' dogs an' fleas come to a feast unca'd.

Hungry dogs are blyth o' bursting puddings.

A Woman and a Greyhound must be small in the waist. 
(From Jacula Prudentium)

The scalded dog fears cold water.

Look not for musk in a dog's kennel.

Who hath a wolf for a mate needs a dog for his man.

Though the mastiff be gentle yet bite him not by the lip.

If the old dog bark he gives counsel.

Little dogs start the hare, the great get her.

An old dog barks not in vain.

George Herbert.

Epitaph on a Dog
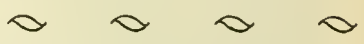

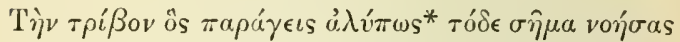

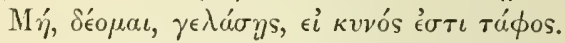

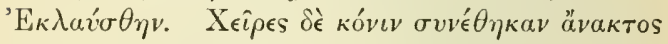

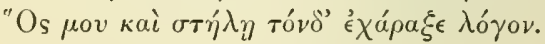

"ONLY a dog!" Yes, here a dog is laid; Yet laugh not, stranger; there was one to love me ;

He wept, dear Master ! when I died, and made This verse to mark the stone that stands above me.

Alfred J. Church. 
(From Far from the Madding Crowd)

CABRIEL had two dogs. George, the elder, exhibited an ebony-tipped nose, surrounded by a narrow margin of pink flesh, and a coat marked in random splotches approximating in colour to white and slaty grey; but the grey, after years of sun and rain, had been scorched and washed out of the more prominent locks, leaving them of a reddish-brown, as if the blue component of the grey had faded, like the indigo from the same kind of colour in Turner's pictures. In substance it had originally been hair, but long contact with sheep seemed to be turning it by degrees into wool of a poor quality and staple.

This dog had originally belonged to a shepherd of inferior morals and dreadful temper, and the result was that George knew the exact degrees of condemnation signified by cursing and swearing of all descriptions better than the wickedest old man in the neighbourhood. Long experience had so precisely taught the animal the difference between such exclamations as "Come in!" and "D__ ye, come in !" that he knew to a hair's breadth the rate of trotting back from the ewes' tails that each call involved, if a staggerer with the sheep-crook was to be escaped. Though old, he was clever and trustworthy still. 
The young dog, George's son, might possibly have been the image of his mother, for there was not much resemblance between him and George. He was learning the sheep-kecping business, so as to follow on at the flock when the other should die, but had got no further than the rudiments as yet-still finding an insuperable difficulty in distinguishing between doing a thing well enough and doing it too well. So earnest and yet so wrong-headed was this young dog (he had no name in particular, and answered with perfect readiness to any pleasant interjection), that if sent behind the flock to help them on, he did it so thoroughly that he would have chased them across the whole county with the greatest pleasure if not called off, or reminded when to stop by the example of old George.

Thus much for the dogs. On the farther side of Norcombe Hill was a chalk-pit, from which chalk had been drawn for generations, and spread over adjacent farms. Two hedges converged upon it in the form of a V, but without quite meeting. The narrow opening left, which was immediately over the brow of the pit, was protected by a rough railing.

One night, when Farmer Oak had returned to his house, believing there would be no further necessity for his attendance on the down, he called as usual to the dogs, previously to shutting them 
up in the outhouse till next morning. Only one responded-old George; the other could not be found, either in the house, lane, or garden. Gabriel then remembered that he had left the two dogs on the hill eating a dead lamb (a kind of meat he usually kept from them, except when other food ran short), and concluding that the young one had not finished his meal, he went indoors to the luxury of a bed, which latterly he had only enjoyed on Sundays.

It was a still, moist night. Just before dawn he was assisted in waking by the abnormal reverberation of familiar music. To the shepherd, the note of the sheepbell, like the ticking of the clock to other people, is a chronic sound that only makes itself noticed by ceasing or altering in some unusual manner from the well-known idle tinkle which signifies to the accustomed ear, however distant, that all is well in the fold. In the solemn calm of the awakening morn that note was heard by Gabriel, beating with unusual violence and rapidity. This exceptional ringing may be caused in two ways - by the rapid feeding of the sheep bearing the bell, as when the flock breaks into new pasture, which gives it an intermittent rapidity, or by the sheep starting off in a run, when the sound has a regular palpitation. The experienced ear of Oak knew the sound he now heard to be caused by the running of the flock with great velocity.

I 95 
He jumped out of bed, dressed, tore down the lane through a foggy dawn, and ascencled the hill. The forward ewes were kept apart from those among which the fall of lambs would be later, there being two hundred of the latter class in Gabriel's flock. These two hundred seemed to have absolutely vanished from the hill. There were the fifty with their lambs, enclosed at the other end as he had left them, but the rest, forming the bulk of the flock, were nowhere. Gabriel called at the top of his voice the shepherd's call.

"Ovey, ovey, ovey!"

Not a single bleat. He went to the hedge-a gap had been broken through it, and in the gap were the footprints of the sheep. Rather surprised to find them break fence at this season, yet putting it down instantly to their great fondness for ivy in winter time, of which a great deal grew in the plantation, he followed through the hedge. They were not in the plantation. He called again : the valleys and farthest hills resounded as when the sailors invoked the lost Hylas on the Mysian shore; but no sheep. He passed through the trees and along the ridge of the hill. On the extreme summit, where the ends of the two converging hedges of which we have spoken were stopped short by meeting the brow of the chalkpit, he saw the younger dog standing against the I $9^{6}$ 
sky-dark and motionless as Napoleon at St. Helena.

A horrible conviction darted through Oak. With a sensation of bodily faintness he advanced: at one point the rails were broken through, and there he saw the footprints of his ewes. The dog came up, licked his hand, and made signs implying that he expected some great reward for signal services rendered. Oak looked over the precipice. The ewes lay dead and dying at its foot-a heap of two hundred carcases, representing in their condition just now at least two hundred more.

As far as could be learnt it appeared that the poor young dog, still under the impression that since he was kept for running after sheep, the more he ran after them the better, had at the end of his meal off the dead lamb, which may have given him additional cncrgy and spirits, collected all the ewes into a corner, driven the timid creatures through the hedgc, across the upper ficld, and by main force of worrying had given them momentum enough to break down a portion of the rotten railing, and so hurled them over the cdge.

George's son had done his work so thoroughly that he was considered too good a workman to live, and was, in fact, taken and tragically shot at 
twelve o'clock that same day--another instance of the untoward fate which so often attends dogs and other philosophers who follow out a train of reasoning to its logical conclusion, and attempt perfectly consistent conduct in a world made up so largely of compromise.

\section{Thomas Hardy.}

A Blenheim's Valentine

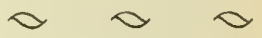

(Written for Mrs. Whateley's "Dandy," 1871)

$\mathrm{T}^{\mathrm{T}}$ was the season of the Saint

1 Of February, when Love's constraint

Pricks every amorous soul to paint

His torments to his mistress,

And rendered tuneful by the time,

Or mindful of his perished prime,

Dandy broke out in doggerel rhyme,

And thus proclaimed his distress :

"The Saint's return, my mistress dear, Which brings to lovers' hearts good cheer, Yet makes them older by a year ;

'Tis with a touch of sorrow, Although good breeding keeps me gay,

I feel the force of what they say, That every dog must have his day, And every dog its morrow. 198 
"Ah! what a season was my youth! How brisk my tail! how sharp my tooth! How clear my bark, which now, forsooth!

Too often turns to snarling!

Then I was valued, as you know, A thousand pounds at every show, The cynosure of Rotten Row,

The boudoir's petted darling.

"Now Age is on me like a blight;

Harsh coughs convulse my sides at night ;

A hazy film o'erspreads my sight ;

'Tis strange how dull my nose is;

My every tooth is almost gone;

I can but trifle with a bone;

Of all my pleasures barely one

Is left me but my dozes.

"The time, too, 's out of joint like ine ; Breeding is gone, and pedigree ; And through the whole dog world I see

The free replace the feudal!

King Charles must be content to live Shorn of his old prerogative, And Blenheim's noble lineage give Room to the shop-born poodle.

"Lowe has repealed the dog-tax; Peace Allows the mongrel to increase ; 
In spite of muzzles and police

The world each day grows cur-rier ;

A gin-bred dwarf usurps the rug ;

Belinda pets a spurious pug;

And Mabel stoops to kiss and hug

A bandy-legged bull terrier.

"With public pique, with private pains,

With age and winter in my veins,

What joy for Dandy's soul remains?

Ah! you, whom dogs entitle

The best of mistresses and friends,

Your favour makes me all amends;

In pleasing you ill-humour ends,

And service finds requital.

"You love me! and content with that

The obsolete aristocrat

Sleeps unrepining on his mat;

So gladly, though I task it,

To your old pensioner's decay,

Your eharity its alms shall pay,

Fine mincemeat and fresh milk by day,

I3y night a cushioned basket.

"These while I live will seem enough;

But when my mortal life-this stuff

That dreams are made of - death shall snuff,

Bury me like a grandee; 
With good dog-Latin epitaph,

Half humorous, pathetic half,

That they who read may weep and laugh,

And say, 'Alas! poor Dandy!'"

William J. Courthope.

The Dog's Point of View

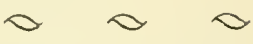

(From Wild Traits in Tame Animals)

THE probable view of the fox-terrier or 1 dachshund which lies upon our hearthrug is that he is one of a pack, the other members of which are the human inhabitants of the house. .. From the dog's point of view his master is an elongated and abnormally cunning $d o g$.

Louis Robinson.

Mike Hourigan's Pup
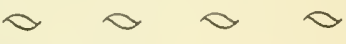

ON'T be shpakin' at all to Mike Hourigan's
pup; 'Tis your wake an' no less av ye're wakin' him up. He denuded the town of sheep, poulthry, an' cats, $\mathrm{An}^{\prime}$ he has himself shtuffed wid ould breeches an' hats. 
Is it poison? - we feasted him times by the score, $A n^{\prime}$ he licked it like butther, an' axed us for more: An' a nate charge of buckshot, why, Andy an' Tim, 1 tell ye 'tis jist vintilation to him.

Small comfort ye'll see

Through the world as ye jog,

If yc're apt to make free

Wid a P'rodesdan dog.

Faith, an' Michael himself got a shmall little taste Of the ways an' the means of that heretic baste. For his grandfather Kelly, the head of the clan, Departed in peace wid the shpagms, poor man! An' his cwoat wid brass buttons, of illigant make, That he bought second-hand for his misthress's wake,

He bequeathed it to Mike, wid his blackthorn an' hat,

For his nateral life, an' his heirs afther that.

Here's a caution to each, -

Through the world as ye jog,

Be houldin' no speech

Wid a Prodesdan dog.

Now Mike, dacent boy, had a girl in his eye, Wid tayshpoons an' cows an' a thrifle laid by ; An', axin no lave of that arrogant brute, He laid himself out in the family shuit. An', what wid the buttons, the chrame in his hair, 
An', maybe, the likes of a kiss here and there, He prospered so well that she gave her consent, The priest would get word for the week before Lent.

Sinall comfort ye'll see

Through the world as ye jog,

If ye're apt to make free

Wid a Prodesdan dog.

"Shure, Michael," says Bridget, "my wits was asthray ;

What would I be afther, forgettin' the tay?"

She shtips to the cupboard, an' "Nusha!" she cries,

"Ye'd be handy at helpin' yourself, I'd surmise.

Make free wid my shpoons! och, it passes belief!"

"Is it me, then," says Nichael, "ye'd make me

a thief?"

"I would, Sorr," says she, wid a catch in the throat, "An" 'tis jinglin' they are in the tail of your cwoat."
Ah! take my advice
Through the world as ye jog,
An' never look twice
At a Prodesdan dog.

"Is it me condiscind to your shpoons an' your cash?

Faix, I'd not soil my hand wid the dirty low thrash. Good day, Miss O'Leary," says Mike, an' wid that He whistles the dog, an' he feels for his hat. 
"Hear that, thin," says Bridget, an', faith, on the word

A noise like a spicial collection was heard; Thin up comes the puppy, from wanderin' at large, Wid cach wag of his tail like a cavalry charge.

Here's a caution to each,-

Through the world as ye jog,

Be houldin' no speech

Wid a Prodesdan dog.

Says Bridget, "Black dhrames to that Prodesdan pup !

My whole expectations, he has thin chewed up!" "Ah! no, thin," says Mike, wid a turn of the eye, "1 wouldn't say 'chewed'; shure, they're only put by.

The fortune's invested securely, why not?

Though it couldn't be rayalized just on the shpot. But, Bicldy asthore, till we have him deceased, It wouldn't be prudent to shpake to the priest." Small comfort ye'll see

Through the world as ye jog, If ye ever make free

Wid a Prodesdan dog.

Frederick Langbridge. 
Argos
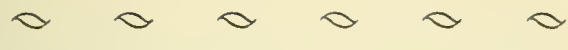

(From The Ody'ssey of Homer, done into English Prose)

THUS they spake one to the other. And lo! a hound raised up his head from where he lay and pricked his ears, Argos, the hound of the enduring Odysseus, which of old himself had bred, but had got no joy of him, for ere that he went to sacred llios. Now in time past the young men used to lead the $\log$ against wild goats and deer and hares; but now was his master gonc, and he lay cast out in the deep dung of mules and kine, whereof he found great plenty spread before the doors, till the thralls of Odysseus should carry it away to dung therewith his wide demesne. There lay the dog Argos, full of vermin. Yet even now when he saw Odysseus standing by, he wagged his tail and dropped both his ears, but nearer to his master he had not the strength to draw. But Odysseus looked aside and wiped away a tear that he easily hid from Eumacus, and straightway he asked him, saying:

"Eumacus, verily this is a great marvel, this hound lying here in the dung. 'Truly' he is goodly of limb, but I know not certainly if he have speed with his beauty, or if he be comcly only as are men's trencher dogs that their lords keep for the pleasure of the cye." 
Then didst thou make answer, swineherd Eumaeus: "In very truth this is the dog of a man that has died in a far land. If he were what once he was in limb and in the feats of the chase, when Odysseus left him to go to Troy, thou wouldst marvel at the sight of his swiftness and his strength. There was no monster that could flee from him in the deep places of the wood, when he was in pursuit; for even on a track he was the keenest hound. But now he is holden in an evil case, and his lord has perished far from his own country, and the careless women take no charge of him. Nay, thralls are no more inclined to honest service when their masters have lost the dominion, for Zeus, of the far-borne voice, takes away the half of a man's virtue, when the day of slavery comes upon him."

Therewith he passed within the fair-lying house, and went straight to the hall, to the company of the proud wooers. But upon Argos came the fate of black death even in the hour that he beheld Odysseus again, in the twentieth year.

S. H. Butcher and A. Lang. 
An Epitaph
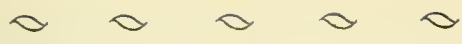

H IS friends he loved. His fellest earthly 11 foes-

Cats-I believe he did but feign to hate.

My hand will miss the insinuated nose,

Mine eyes the tail that wagg'd contempt at Fate.

William H'atson.

A Study in Contrasts ${ }^{1}$

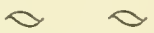

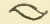

$\mathrm{B}^{\mathrm{Y} \text { cliff and chine, and hollow-nestling wood }}$ Thrilled with the poignant savour of the sea, All in the crisp light of a wintry morn, We walked, my friend and I, preceded still Iyy one whose silken and voluminous suit, His courtly ruff, snow-pure 'mid golden tan, His grandly feathered legs slenderly strong, The broad and flowing billow of his breast, His delicate ears and superfine long nose, With that last triumph, his distinguished tail, In their collective glory spolie his race The flower of Collie aristocracy. Yet, from his traits, how absent that reserve, That stillness on a base of power, which marks, In men and mastiffs, the selectly sprung!

1 We gite here the first half of the poem, the second half tells of an Angora Cat. 
For after all, his high-life attributes,

His trick of doing nothing with an air,

His salon manners and society smile,

W'ere but skin-deep, factitious, and you saw

The bustling despot of the mountain flock,

And pastoral dog-of-all-work, underlie

The fashionable modern lady's pet, -

Industrial impulses bereft of scope,

Duty and discipline denied an aim,

Ancestral energy and strenuousness

In graceful trifling frittered all away.

Witness the depth of his concern and zeal

About minutest issues: shall we take

This path or that?-it matters not a straw-

But just a moment unresolved we stand,

And all his personality, from ears

To tip of tail, is interrogative ;

And when from pure indifference we decide,

How he vociferates! how he bounds ahead!

With what erthusiasm he ratifies,

Applauds, acclaims our choice 'twixt right and left,

As though some hoary problem over which

The world had puckered immemorial brows,

Were solved at last, and all life launched anew !

These and a thousand tricks and ways and traits

I noted as of Demos at their root,

And foreign to the staid, conservative,

Came-over-with-the-Conqueror type of mind. 208 
And then, his nature, how impressionable, How quickly moved to Collie mirth or woe, Elated or dejected at a word! And how unlike your genuine Vere de Vere's Frigid, indifferent, half-ignoring glance At everything outside the sacred pale Of things De Veres have sanctioned from the Flood,

The unweariable curiosity

And universal open-mindedness of that all-testingr, all-inquisitive nose !

\section{IVillian Watson.}

\section{The Carrier Dog of Berlin}
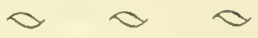

F E goes between the shafts all day,

1 Dear, patient, burden-bearing fellow ;

In every street I pass him-grey,

Or brown, or black, or ugly yellow.

He drags along the flinty road

A little cart, which, low and narrow,

Seems yet a disproportioned load;

Or, happy chance, the slighter barrow.

Beside him, sharer in the strain,

A fellow-toiler goes, the master:

He lends a hancl, and shouts amain,

To check his loeast, or urge him faster.

$$
\text { '? }
$$


They halt where business gives them cause :

Set free a moment from the traces

He lies with nose between his paws,

Or secks a friend in passing faces.

About him sport, with leisured air,

"King Charles" and "Teckel," hound and terrier;

He eyes them with a patient stare;

More sober he, as they the merrier.

Some wistful feclings may arise

At so much play while he is working,

Yet in his thoughtful ycllow eyes

No shade of discontent is lurking.

But still between the shafts he goes,

In quietness his mind possessing.

He lives his life, and, living, knows

That comfort lies in acquiescing.

Mary Armstrong.

Choosing a Shepherd's Dog

(From Owd Bob)

T the choosing of his dog, a shepherd must 1 exercise as fully fastidious a care as in the choosing of his wife. For the one may be his better, the other is his business half. In pairharness they have to earn their daily bread; share 
ambitions, perils, sorrows, joys, sun, and snow ; and in the end they grow to be rather one divided than two conjoined.
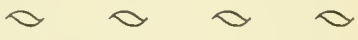

A RARE thing it was for the little man and his A Red Wull to be apart. So rare that others besides the men in that little tap-room noticed it.

Saunderson's old Shep walked quietly to the back-door and looked out. There on the slope below him he saw what he sought, stalking up and down, gaunt and grim, like a lion at feedingtime. And as the old dog watched, his tail was slowly swaying as though he were well pleased.

He walked back into the tap-room just as Teddy begran his tale. Twice he made the round of the room, silent-footed. From dog to dog he went, stopping at each as though urging him on to some great enterprise; then he made for the door again, looking back to see if any followed.

One by one the others rose and trailed out after him : big blue Rasper; Londesley's Lassie; Ned Hoppin's young dog; Grip and Grapple, the publican's bull-terriers; Jim Mason's Gyp, foolish and flirting even now; others there were; and last of all, waddling in the rear, that scarred Amazon, the Venus. 
Out of the house they pattered, silent and unseen, with murder in their hearts. At last they had found their enemy alone. And slowly, in a black cloud, like the Shadow of Death, they dropped down the slope upon him.

And he saw them coming, knew their errand, as who should better than the Terror of the Border, and was glad. Death it might be, and such an one as he would wish to die; at least distraction from that long-drawn, haunting pain. And he grinned as he looked at the approaching crowd and saw there was not one there but he had humbled in his time.

He ceased his restless pacing, and awaited them. His great head was high as he scanned them contemptuously, daring them to come on.

And on they came, marching slow and silent like soldiers at a funcral: young and old; bobtailed and bull; terrier and collie, flocking like vultures to the dead. And the Venus, heavy with years, rolled after them on her bandy legs, panting in her hurry lest she should be late: for had she not the blood of her blood to avenge?

So they came about him, slow, certain, murclerous, opening out to cut him off on every side.

There was no need. He never thought to move. Long odds 'twould be-crushingly heavy ; yet lie loved them for it, and was trembling already with the glory of the coming fight. 
They were up to him now; the sheep-dogs walking round him on their toes, stiff and short like cats on coals; their backs a little humped, heads averted, yet eyeing him askance.

And he remained stock still, nor looked at them. His great chin was cocked, his muzzle wrinkled in a dreadful grin. As he stood there, shivering a little, eyes rolling back, breath grating in his throat to set every bristle on edge, he looked infernal.

The Venus ranged alongside him. No preliminary stage for her: she never walked where she could stand or stood where she could lie. But stand she must now, breathing hard through her nose, never taking her eyes off that pad she had marked for her own. Close beside her were crop-eared Grip and Grapple, looking up at the line above them where hairy neck and shoulder joined. Lehind was big Rasper, and close to him, Lassie. Of the others each had marked his place, each taken up his post.

Last of all, old Shep took his stand full in front of his enemy, their shoulders almost rubbing, head past head.

So the two stood a moment, as though whispering; each diabolic, each rolling back red eyes to watch the other; while from the little mob there rose a snarling, bubbling snore, like giants wheering in their sleep.

Then like lightning each struck. Rearing high, 
they wrestled with striving paws and the expression of fiends incimate. Down they went, Shep underneath, and the great $\log$ with a dozen of these wolves of hell upon him. Rasper, devilish, was riding on his back; the Venus-well for him -had struck and missed ; but Grip and Grapple had their hold; and the others, like leaping demoniacs, were plunging into the whirlpool vortex of the fight.

And there, where a fortnight before he had fought and lost the battle of the Cup, Red Wull now battled for his life.

Long odds: but what cared he? The longdrawn agony of the night was drowned in that glorious delirium ; the hate of years came bubbling forth. In that supreme moment he would avenge his wrongs on humanity. And he went in to fight, revelling like a giant in the red lust of killing.

Long odds. Never before had he faced such a galaxy of foes. His one chance lay in quickness: to prevent the swarming crew getting their hold till at least he had diminished them.

Then it was a sight to see the great brute, huge as a bull-calf, strong as a bull, rolling over and over and up again, quick as a kitten; leaping here, striking there; shaking himself free; swinging his quarters; fighting with feet and body and teeth-every inch of him at war. More than once he broke through the ruck; only 
to turn again. No flight for him, nor thought of it.

Up and down the slope the dark mass tossed, like some hulk the sport of waves. Black and white, sable and grey, worrying at that great centrepiece; up and down, roaming wide, leaving everywhere a trail of red.

Gyp he had pinned and hurled across his shoulder. Grip followed: he shook her till she rattled, then flung her afar; and she fell with a horrible thud, not to rise; while Grapple, the death to avenge, hung tighter. In a scarlet soaking patch of the ground lay Kirby's lurcher, doubled up in a dreadful ball. And Hoppin's young dog, who three hours before had been playing tenderly with the children, now fiendish to look on, dragged after the huddle up the hill. Back the mob rolled on her. When it was passed, she lay quite still, grinning, a handful of tawny hair and flesh in her dead mouth.

So they fought on. And ever and anon a great figure rose up from the inferno all around, rearing to his full height, his head all ragged and bleeding, the red foam dripping from his jaws. Thus he would appear momentarily, like some dark rock amidst a raging sea; and down he would go again.

Silent now they fought, dumb and determined. Only you might have heard the rend and rip of tearing flesh; a hoarse gurgle as some dog went 
down; the panting of dry throats; and now and then a sob from that central figure. He was fighting for his life. The Terror of the Border was at bay.

All who meant it were on him now. The Venus had her hold at last; and never but once in a long life of battles lad she let go; Rasper, his breath coming in dreadful rattles, clipped him horribly by the loins; while a dozen other devils with hot eyes and wrinkled nostrils clung still.

Long odds. And down he went, smothered beneath the weight of numbers, yet struggled up again; his great head torn and dripping, eyes a gleam of rolling red and white, the little tail stern and stiff like the stump of a flagstaff shot away. He was desperate but indomitable; and he sobber as he fought doggedly on.

Long odds: it could not last. And down he went at length, silent still-never a cry sbould they wring from him in his agony: the Venus glued to that mangled pad; Rasper beneath him now; three at his throat; two at his ears; a crowd on flanks and body.

The Terror of the Border was overwhelmed at last.

"Wullie! ma Wullie!" screamed M'Adam, bounding down the slope a crook's length in front of the rest. "Wullie! Wullie! to me!" 
At the cry the huddle below was convulsed. It heaved and swayed and dragged to and fro, like the sea lashed into life by some dying leviathan.

A gigantic figure, tawny and red, fought its way to the surface. A great tossing head, gory past recognition, flung out from the ruck. One quick glance he shot from ragged eyes at the little flying figure in front; then with a roar like a waterfall plunged towards it, shaking off the bloody leeches as he went.

"Wullie! Wullie! I'm wi' ye!" cried that little voice, now so near.

Through-through-through ! an incomparable effort, and his last.

They hung to his throat, they clung to his muzzle, they were round and about him.

Down he went again with a sob and a little suffocating cry, shooting up at his master one quick beseeching glance as the sea of blood closed over him - worrying, smothering, tearing, like foxhounds at the kill.

They left the dead, and pulled away the living. And it was no light task, for the pack were mad for blood.

At the bottom of the wet mess of hair and red and flesh was old Shep, stone-dead. And as Saunderson pulled the body out, his face was 
working; for no man can lose in a crack the friend of a dozen years and remain unmoved.

The Venus lay there, her teeth clenched still in death; smiling that her vengeance was achieved. Big Rasper, blue no longer, was gasping out his life. Two more came crawling out to find a quict spot where they might lay them down to die. Before the night had fallen another had gone to his account; while not a dog who fought upon that day but carried the scars of it to his grave. 'The Terror o' th' liorder, terrible in his life, like Samson, was yet more terrible in his dying.

Alfred Olivant.

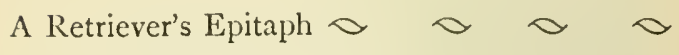

BENEATH this turf, that formerly he pressed With agile feet, a Dog is laid to rest;

Him, as he sleeps, no well-known sound shall stir, The rabbit's patter or the pheasant's whirr; The keeper's "Over!"-far, but well defined, That speeds the startled partridge down the wind; The whistled warning, as the winged ones rise Large and more large upon our straining eyes, Till with a sweep, while every nerve is tense, The chattering covey hurtles o'er the fence; The double crack of every lifted gun; The dinting thud of birds whose course is done218 
These sounds, delightful to his listening ear, He heeds no longer, for he cannot hear.

None stauncher, till the drive was done, defied Temptation, rooted to his master's side; None swifter, when his master gave the word, Leapt on his course to track the running bird, And bore it back - ah, many a time and oft ! His nose as faultless as his mouth was soft. How consciously, how proudly unconcerned Straight to his master's side he then returned, Wagged a glad tail and deemed himself repaid, As in that master's hand the bird he laid;

If, while a word of praise was duly said, The hand should stroke his smooth and honest head.

Through Spring and Summer, in the sportless days,

Checrful he lived a life of simpler ways:

Chose, since official dogs at times unbend, The household cat for confidante and friend; With children, friendly but untaught to fawn, Romped through the walks and rollicked on the lawn ;

Rejoiced, if one the frequent ball should throw, To fetch it, scampering gaily to and fro, Content through every change of sportive mood If one dear voice, one only, called him good. Such was my Dour, who now without my aid Hunts through the shadowland, himself a sliade ; 
Or, couched intent before some ghostly gate, Waits for my step, as here he used to wait.

kobert C. Lehmann.

To Rufus, a Spaniel
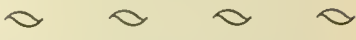

RUFUS, a bright Ncw Year! A savoury stew, 1 Boncs, broth and biscuits, is prepared for you.

See how it steams in your enamelled dish, Mixed in each part according to your wish.

Hide in your straw the bones you cannot crunchThey'll come in handy for to-morrow's lunch ; Abstract with care each tasty scrap of meat, Remove each biscuit to a fresh retreat (A dog, I judge, would deem himself disgraced Who ate a biscuit where he found it placed); Then nuzzle round and make your final siwcep, And sleep, replete, your after-dinner sleep. High in our hall we've piled the fire with logs For you, the doyen of our corps of dogs.

There, when the stroll that health demands is done, Your right to ease by due exertion won, There shall you come, and on your long-haired mat,

Thrice turning round, shall tread the jungle flat, And, rhythmically snoring, dream away The peaccful evening of your New Year's day. 
Rufus! there are who hesitate to own Merits, they say, your master sees alone. They judge you stupid, for you show no bent To any poodle-dog accomplishment.

Your stubborn nature never stooped to learn Tricks by which mumming dogs their biscuits earn.

Men mostly find you, if they change their seat, Couchant obnoxious to their blundering feet ; Then, when a door is closed, you steadily Misjudge the side on which you ought to be ; Yelping outside when all your friends are in, You raise the echoes with your ceaseless din, Or, always wrong, but turn and turn about, Howling inside when all the world is out. They scorn your gestures and interpret ill Your humble signs of friendship and good will; Laugh at your gambols, and pursue with jeers The ringlets clustered on your spreading ears; See without sympathy your sore distress When Ray obtains the coveted caress, And you, a jealous lump of growl and glare, Hide from the world your head beneath a chair. They say your legs are bandy-so they are : Nature so formed them that they might go far, They cannot brook your music; they assail The joyful quiverings of your stumpy tailIn short, in one anathema confound Sliape, mind and heart, and all my little hound. 
Well, let them rail. If, since your life began, Beyond the customary lot of man

Staunchness was yours; if of your faithful heart Malice and scorn could never claim a part; If in your master, loving while you live, You own no fault or own it to forgive; If, as you lay your head upon his knee, Your deep-drawn sighs proclaim your sympathy; If faith and friendship, growing with your age, Speak through your eyes and all his love engage; If by that master's wish your life you ruleIf this be folly, Rufus, you're a fool.

Old dog, content you; Rufus, have no fear: While life is yours and mine your place is here. And when the day shall come, as come it must, When Rufus goes to mingle with the dust (If Fate ordains that you shall pass before To the abhorred and sunless Stygian shore), I think old Charon, punting through the dark, Will hear a sudden friendly little bark; And on the shore he'll mark without a frown A flap-eared doggie, bandy-legged and brown. He'll take you in : since watermen are kind, He'd scorn to leave my little dog behind. He'll ask no obol, but instal you there On Styx's further bank without a fare. There shall you sniff his cargoes as they come, And droop your liead, and turn, and still be dumb- 
Till one fine day, half joyful, half in fear,

You run and prick a recognising car,

And last, ol, rapture! leaping to his hand,

Salute your master as he steps to land.

Robert C. Lehmann.

\section{In Memoriam $\propto \propto \propto \propto \propto$}

I MISS the little wagging tail;

I I miss the plaintive pleading wail;

I miss the wistful loving glance;

I miss the circling welcome-dance.

I miss the eyes that watching sued;

I miss her tongue of gratitude

That licked my hand, in loving mood,

When we divided cup or food.

I miss the pertinacious scratch

(Continued till I raised the latch

Each morning), waiting at my door:

Alas! I ne'er shall hear it more.

"What folly!" hints the cynic mind, "I'lenty of dogs are left behind To snap and snarl, to bark and bite, And wake us in the gloomy night. 
"You should have sought a human friend, Whose life eternal ne'er could end,-

Whose gifts of intellect and grace Bereavement never could efface."

Plenty of snarling things are left; But I am of a friend bereft;

I seek not intellect, but heart, -

'Tis not my head that feels the smart.

While loving sympathy is cherish'd ;

While gratitude is not quite perish'd ; While patient, hopeful, cheerful meeting At our return is pleasant greeting;

So long my heart will feel a void,Grieving, my mind will be employ'd,When $I$, returning to my door, Shall miss what I shall find no more.

When we, at last, shall pass away, And see no more the light of day, Will many hearts as vacant mourn,As truly wish for our return?

Yet love that's true will ever know The pain of parting. Better so! "Better to love and lose" than cold, And colder still, let hearts grow old. 
So, let the cynic snarl or smile, And his great intellect beguile;

My little dog, so true to me,

Will dear to heart and memory be :

Henry Willett. 


\section{TO THE MEMORY}

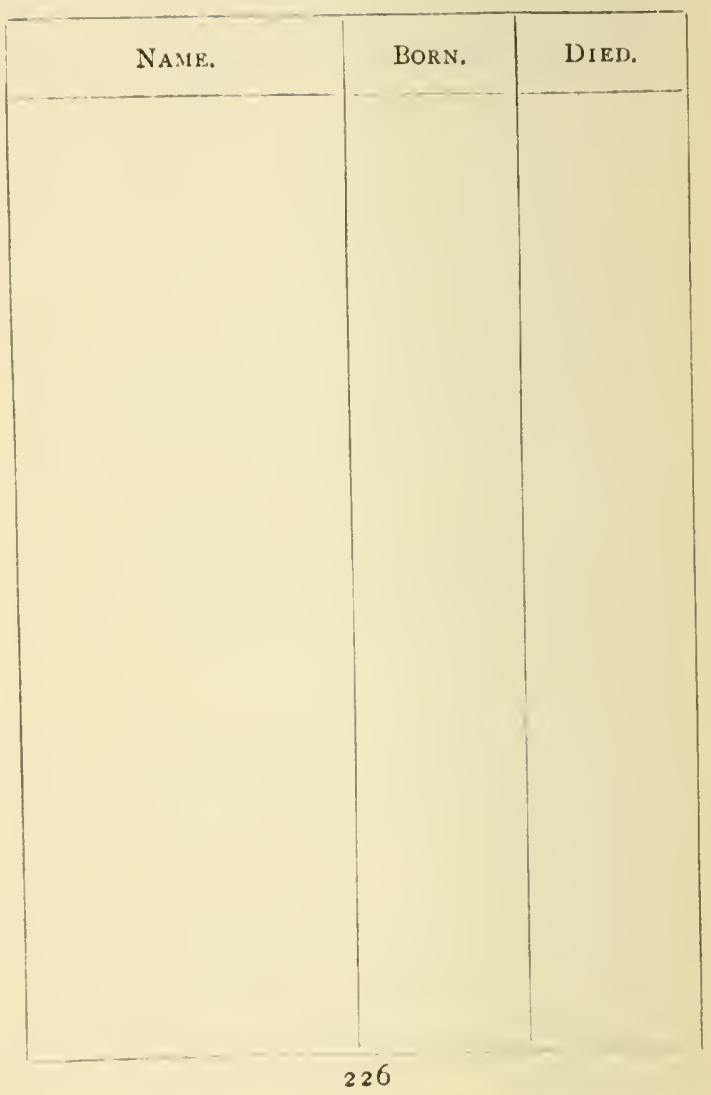




\section{OF FAITHFUL DOGS}

ViRTUES. 
TO THE MEMORY

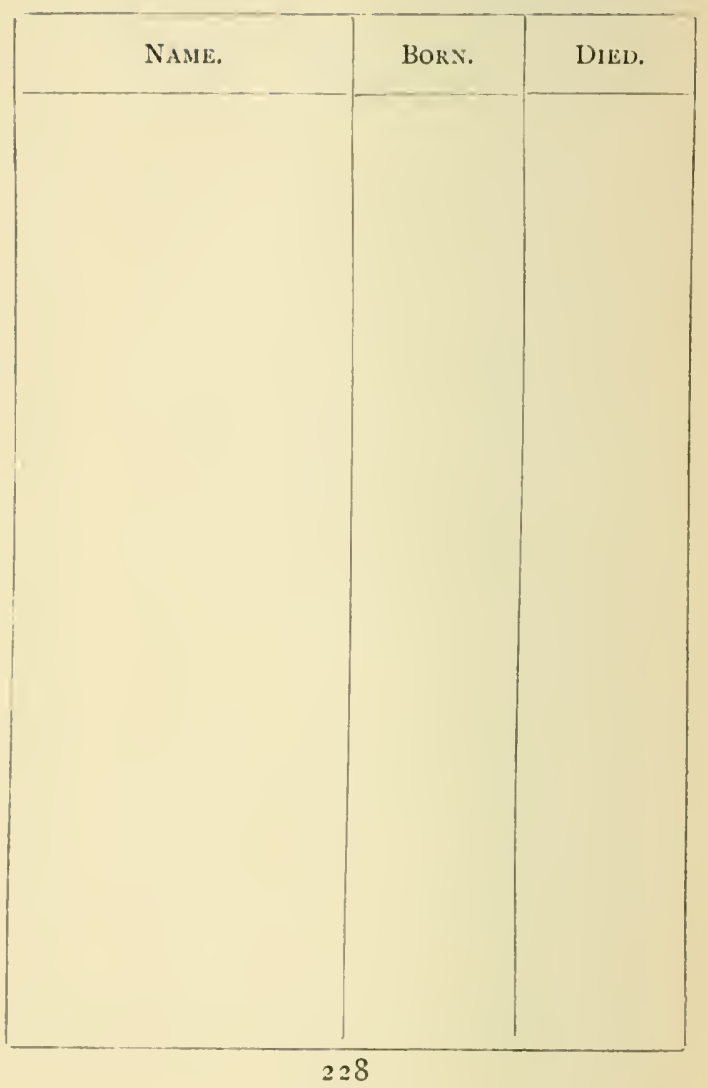




\section{OF FAITHFUL DOGS}

Virtues. 



\section{INDEX TO AUTHORS}

Esop, 33, 34, 36

Armstrong, Mary, 209

Blackcock, Thomas, $8 \mathrm{I}$

Bowles, William Lisle, ro5

Brown, John, I7 7

Browning, Elizabeth Barrett, 16+169

Browning, Robert, I 87

Buffon, George, 80

lsurns, Robert, IOI, I03, 10.4

Butcher, S. H., 205

Byron, George, I 60

Caius, Johannes, I I

('amerarius, Philipp, 26

Church, Alfred J., I92

Cicero, I

Courthope, William J., 198

Cowper, 11 illiam, 84,85 , $87,88,89,90$

Crable, (jeorge, 99

Cuvier, (jeorges, 106

Darwin, Charles, I 70
Dickens, Charles, 182

Doyle, Francis, I79

Drayton, Michael, 24

Eldon, 98

Eliot, George, I9o

Fielding, Henry, 8 r

Fleming, Abrahan, I I Florio, 8

Gay, John, 6o, 62, 63, 65

Goldsmith, Oliver, 83

Hanilton, W'illiam (Litut.), 39

Hamilton, William, 79

Hardy, Thomas, 193

Harrington, John, it

IIerbert, George, 192

IItrrick, Robert, 2o

Hogg, Janies, 1 i 1

Ilomer, 72, 205

Houghton, Johı, ;2

Ingoldsty, Thomas, 162 
Lamb, Charles, If I, I 42

Landor, Walter Savage,

I.F. I 45

L.aneham, R., 25

I.ang, . \., 205

Langbridge, Frederick, $20 \mathrm{I}$

1.ehmann, Robert C., 218, 220

Jucian, 5

Macaulay, $I_{3}$

Misson, 77

Molle, John, 26

Montaigne, 8

North, Thomas, 4

Olivant, Alfred, 2 so

Pepys, Samuel, 32

Plilips, Katherine, 36

Pindar, l'eter, 9

Plutarch, 1, 2, 4

Pope, Alexander, 72, 73, 74

Pratt, Samuel Jackson, 9.4

l'rior, Natthew, 38
Richards, F. T., I

Robinson, Louis, 201

Scott, W'alter, 122, 127 . I 30, I 35

Shakespeare, William, I8, 20

Smart, Christopher, 82

Somerville, William, 45

Southey, Caroline Buwles, 145

Southey, Robert, 138, 139

Spencer, Rolsert WI., 106

Swift, Jonathan, 58

'Thomson, James, 79

'Tickell, 'Thomas, 69

'Tooke, W., 5

Turberville, George, 7

Walpole, Horace, 8I

Walton, Izaak, 2 I

Watson, William, 207

Willett, Henry, 223

Wordsworth, W'illiam, 116 , I I 9, I 20 
This book is DUE on the last date stamped below.
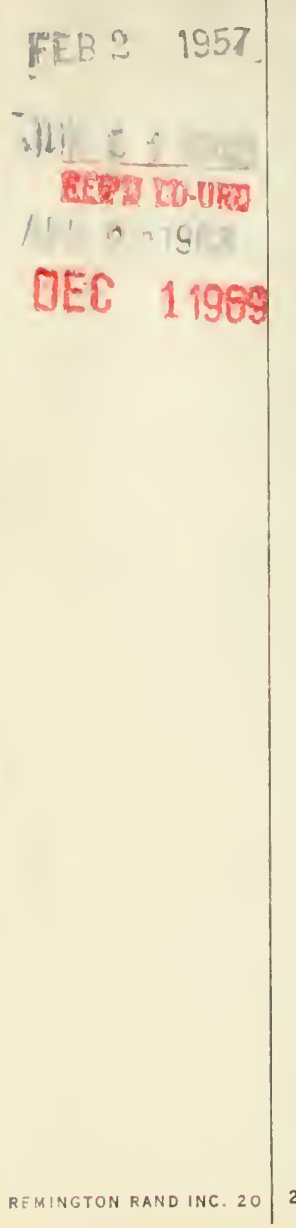
UC SOUTHERN REGIONAL LIBRARY FACILITY |||||||||||||||||||||||||||||||||||| AA $000419116 \quad 9$ 


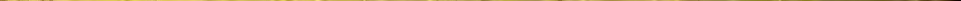

